\title{
Therapeutic potential of glutathione-enhancers in stress-related psychopathologies
}

Ioannis Zalachoras ${ }^{\mathrm{a}}$, Fiona Hollis ${ }^{\mathrm{a}}$, Eva Ramos-Fernández ${ }^{\mathrm{a}}$, Laura Trovo ${ }^{\mathrm{b}}$, Sarah Sonnay ${ }^{\mathrm{b}}$, Eveline Geiser $^{\mathrm{b}}$, Nicolas Preitner ${ }^{\mathrm{b}}$, Pascal Steiner ${ }^{\mathrm{b}}$, Carmen Sandi ${ }^{\mathrm{a}}$, Laia Moratón ${ }^{\mathrm{a}, *}$

a Laboratory of Behavioral Genetics, Brain Mind Institute, École Polytechnique Fédérale de Lausanne, 1015 Lausanne, Switzerland

b Société des Produits Nestlé S.A., Nestlé Research, Vers-chez-les-Blanc, 1000 Lausanne 26, Switzerland

* Corresponding author. E-mail address: laia.moratofornaguera@epfl.ch (L. Morató) 


\begin{abstract}
The mammalian brain has high energy demands, which may become higher in response to environmental challenges such as psychogenic stress exposure. Therefore, efficient neutralization of reactive oxygen species that are produced as a by-product of ATP synthesis is crucial for preventing oxidative damage and ensuring normal energy supply and brain function. Glutathione (GSH) is arguably the most important endogenous antioxidant in the brain. In recent years, aberrant GSH levels have been implicated in different psychiatric disorders, including stress-related psychopathologies. In this review, we examine the available data supporting a role for GSH levels and antioxidant function in the brain in relation to anxiety and stress-related psychopathologies. Additionally, we identify several promising compounds that could raise GSH levels in the brain by either increasing the availability of its precursors or the expression of GSH-regulating enzymes through activation of Nuclear factor erythroid-2-related factor 2 (Nrf2). Given the high tolerability and safety profile of these compounds, they may represent attractive new opportunities to complement existing therapeutic manipulations against stress-related psychopathologies.
\end{abstract}

\title{
Keywords
}

Psychogenic stress; Brain; Mitochondria; Oxidative stress; Glutathione (GSH); Nuclear factor erythroid-2-related factor 2 (Nrf2); Depression; Anxiety; N-acetyl-cysteine; Glycine; Taurine; Whey proteins; Glutamine; Sulforaphane; Dimethyl fumarate; Curcumin; Melatonin; Trehalose; Ergothioneine; L-carnitine; Puerarin 


\section{Table of contents}

1. The link between psychogenic stress, brain energetics and oxidative stress

2. Evidence of GSH decrease under conditions of psychogenic stress ....................6

3. Compounds with potential to modulate brain GSH levels $\ldots \ldots \ldots \ldots \ldots \ldots \ldots \ldots \ldots \ldots \ldots$

3.1 Enhancing GSH through GSH precursors treatments .........................11

$3.1 .1 \mathrm{~N}$-acetyl-cysteine ..............................................

3.1 .2 Glycine ................................................................. 13

3.1.3 Taurine ............................................................ 15

3.1.4 Whey proteins ...................................................17

3.1.5 Glutamine ...................................................... 18

3.2 Enhancing GSH through Nrf2 activation ...................................20

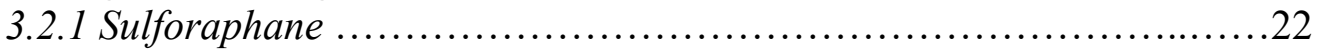

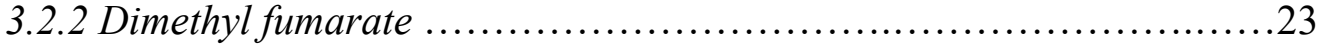

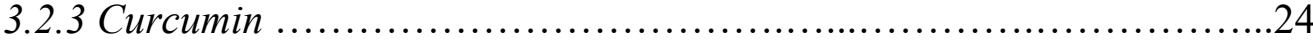

3.2.4 Melatonin .....................................................25

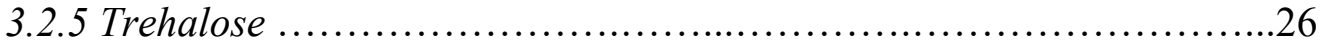

4. Alternative strategies to increase glutathione levels ................................27

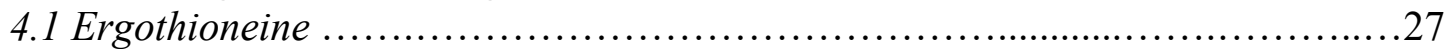

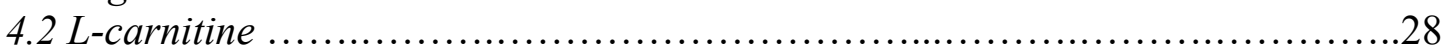

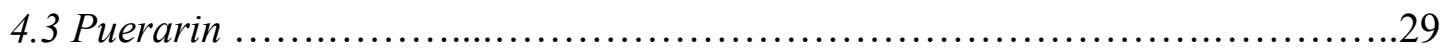

5. Safety and tolerability of GSH precursors and Nrf2 activators .........................29

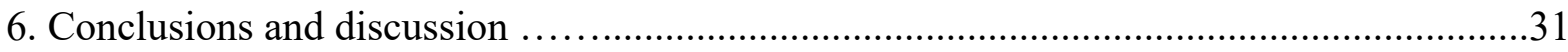

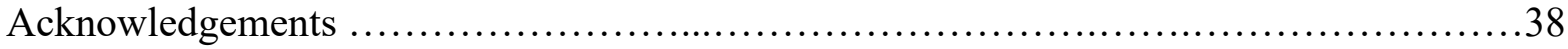

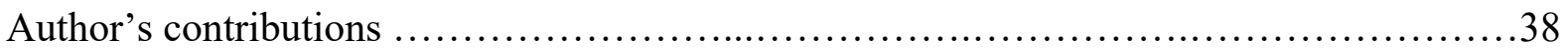

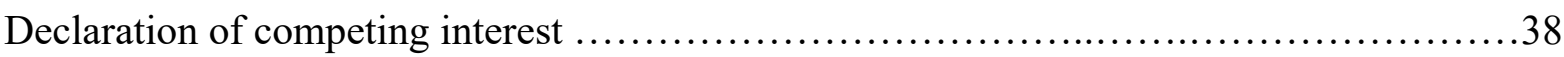

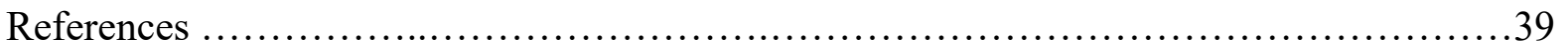




\section{The link between psychogenic stress, brain energetics and oxidative stress}

Psychogenic stress is defined as a state of imminent or perceived threat to homeostasis, where the brain and body invoke various physiological responses to adapt (de Kloet, Joels et al. 2005; de Kloet, de Kloet et al. 2019). In acute situations, the stress response helps the organism mobilize the resources needed to either meet or prepare for a physical or psychological challenge (Herman and Tasker 2016). For instance, during stress, cerebral energy metabolism, including the oxidation of glucose and the consumption of oxygen $\left(\mathrm{O}_{2}\right)$, increases substantially (Bryan 1990). However, the same mediators of the stress response also exert pathological actions when overused, such as under conditions of chronic exposure. Chronic stress is indeed a risk factor for psychopathologies such as anxiety and depression (McEwen 2017). Epidemiological studies have shown that stress-related psychopathology (anxiety disorders, mood disorders and PTSD) may affect more than 100 million people in Europe alone (Gustavsson, Svensson et al. 2011; Wittchen, Jacobi et al. 2011), revealing the urgent need to understand the molecular mechanisms underlying these disorders in order to develop new effective treatments.

In the last decade, the role of oxidative damage (described below) has gained attention in stress-related disorders. Several studies in depressed patients show increased levels of oxidative stress markers including lipid peroxidation [(i.e. F2-isoprostanes, Malondialdehyde (MDA)] (Dimopoulos, Piperi et al. 2008; Yager, Forlenza et al. 2010; Bajpai, Verma et al. 2014) and RNA/DNA oxidation (i.e. 8-Oxo2'-deoxyguanosine, 8-OHdG) in plasma and post-mortem brain samples (Irie, Miyata et al. 2005; Forlenza and Miller 2006; Che, Wang et al. 2010; Palta, Samuel et al. 2014; Black, Bot et al. 2015; Szebeni, Szebeni et al. 2017). Increased oxidative markers are also observed in the brains of rodents subjected to different stress protocols including maternal deprivation (Uysal, Gonenc et al. 2005), social isolation (Serra, Pisu et al. 2005), social defeat (Bouvier, Brouillard et al. 2016) and chronic variable stress (Herbet, Korga et al. 2017a).

Why are brain energetics and oxidative damage gaining lately so much attention in stress-related psychopathologies? Under basal conditions, the brain consumes more than $20 \%$ of the $\mathrm{O}_{2}$ and glucose used by the human body, despite representing only $2 \%$ of the total body mass (Clark and Sokoloff 1999). Mitochondria use oxygen and the energy stored in glucose, the main source of energy in the 
brain, to generate adenosine triphosphate (ATP), in a process called oxidative phosphorylation (OXPHOS) (Herrero-Mendez, Almeida et al. 2009; Reeve, Krishnan et al. 2011). In neurons, ATP is subsequently used to support a broad range of brain functions, with synaptic activity and action potential firing being particularly energy demanding (Hall, Klein-Flügge et al. 2012; Harris, Jolivet et al. 2012). In astrocytes, oxidative metabolism also results in a large production of ATP which is essential to support blood flow regulation, neuronal activity modulation and protection against oxidative stress (Sonnay, Gruetter et al. 2017).

Remarkably, during OXPHOS electrons can also bypass the formation of ATP and generate reactive oxygen species (ROS). Therefore, in situations of enhanced energy demand (e.g. when a brain region is activated) (Hall, Klein-Flügge et al. 2012; Harris, Jolivet et al. 2012) the production of ATP is accompanied by an increase in mitochondrial ROS production (Murphy 2009). Although ROS have important physiological roles as signaling molecules (McCord 1974; Weissmann, Smolen et al. 1980; Scherz-Shouval, Shvets et al. 2007), neutralizing excessive ROS production is essential to prevent oxidative stress and oxidative damage (Halliwell 2006) that could ultimately damage mitochondria and impair energy production (Stefanatos and Sanz 2018). Despite the presence of other extra-mitochondrial sources of ROS in the brain (e.g. NADPH oxidases, monoamine oxidase and peroxisomal enzymes), mitochondrial ROS overproduction has been shown to be critically involved in several neurological conditions and neurodegenerative diseases (Angelova and Abramov 2018). Importantly, the brain is particularly susceptible to oxidative damage not only due to its high rate of $\mathrm{O}_{2}$ consumption but also due to the high abundance of peroxidizable polyunsaturated fatty acids in neuronal membrane lipids and the relatively poor expression and activity of antioxidant enzymes. For instance, compared to liver, the activity levels of glutathione peroxidase (GPx), glutathione reductase (GSR) and superoxide dismutase (SOD) in the brain are 10, 7.5 and 2 times lower, respectively (Hariharakrishnan, Anand et al. 2009; Nagar, Khan et al. 2015). Other factors conferring additional vulnerability include the high iron content in some brain regions (e.g. substantia nigra and basal ganglia) which catalyses the generation of ROS, or the capacity of some neurotransmitters (e.g. dopamine and serotonin) to be autooxidized to quinones and semiquinones in a process that generates ROS as well (Friedman 2011; Cobley, Fiorello et al. 2018). 
The body relies on both endogenous and exogenous antioxidant defenses to deal with ROS including degrading enzymes (e.g. SOD, GPx, GSR and catalase) and non-enzymatic compounds [(e.g. dietary vitamins such as vitamins $\mathrm{A}, \mathrm{C}$, and $\mathrm{E}$, and endogenous compounds such as melatonin, L-carnitine, and glutathione (GSH)] (Fraunberger, Scola et al. 2016). The production of these antioxidants is mainly regulated by a redox-sensitive transcription factor named nuclear erythroid-2 like factor-2 (Nrf2), which binds specific response elements in the promoter sequences of antioxidant genes to promote their transcriptional activation under high conditions of ROS (Dringen 2000). Of these antioxidants, the most important and abundant is GSH (see Box 1 and Fig. 1). Unlike other cellular antioxidants that target a specific type of ROS, GSH is an endogenous compound that protects against multiple oxidative insults (Mizui, Kinouchi et al. 1992; Dringen, Pawlowski et al. 2005). Notably, neurons require high levels of GSH to counteract oxidative stress and maintain proper brain structural integrity and cognitive function (Fernandez-Fernandez, Bobo-Jimenez et al. 2018).

As mentioned above, one of the situations leading to increased oxidative stress in the brain is psychogenic stress, a situation in which there is a concomitant increase in ROS production due to increased brain energy demand, and a decrease in antioxidant defense mechanisms. Due to the increased energetic toll that stress exposure exerts on the brain (Morava and Kozicz 2013; Picard, McEwen et al. 2018), and the importance of GSH to neuronal function, it comes as no surprise that GSH levels and

related genes have been found altered under stress conditions or stress-related psychopathologies. The purpose of this review is, therefore, to provide a synthesized overview of the current literature presenting evidence that GSH levels in the brain are decreased in stress-related psychopathologies. Moreover, we will identify the most promising compounds that have been used to boost GSH levels in the brain and their potential to combat these mental disorders both in humans and in animal models.

\section{Evidence of GSH decrease under conditions of psychogenic stress}

A number of preclinical studies have reported a link between exposure to stress and decreased levels of GSH and GSH-related enzymes. Glucocorticoids, the main hormone from the hypothalamic-pituitaryadrenal (HPA) axis secreted in response to stress, have been shown to negatively impact the levels of antioxidants, including GSH. In vitro, glucocorticoids were found to decrease GSH levels and inhibit 
GPx activity in hippocampal neuronal cultures (Patel, McIntosh et al. 2002). Additionally, several studies have reported that glucocorticoid administration in rodents in vivo leads to decreased GSH levels, downregulated expression of various antioxidants genes, including GPx and catalase, and increased ROS in several brain regions (McIntosh, Hong et al. 1998; Sato and Stryker 2010; Beytut, Yilmaz et al. 2018). Similarly, studies that exposed animals to chronic stress found evidence for drastic alterations in the ROS and GSH systems. For instance, repeated restraint stress both in adult rats (Liang, Wang et al. 2015; Samarghandian, Azimi-Nezhad et al. 2017a) and in adult mice (Seo, Park et al. 2012) led to increased lipid peroxidation and decreased levels of GSH and related antioxidant enzymes in several brain regions, including the cortex, striatum, and hippocampus. These effects of stress may depend, at least partially, on stress-induced elevations in glucocorticoids (Zafir and Banu 2009a). Psychosocial stress has a negative impact on the GSH system, as well. GSH and GSH-related enzymes -including GPx and GSR- were found to be decreased in the hippocampus following 3 weeks of social isolation (Djordjevic, Djordjevic et al. 2010), while the reduced to oxidized glutathione ratio (GSH/GSSG) decreased in the striatum and cortex following 8 weeks of social isolation (Möller, Du Preez et al. 2011). Similarly, exposure of adult rats to chronic social defeat (Solanki, Salvi et al. 2017) or a chronic regime of variable stressors, including social isolation (Herbet, Korga et al. 2017b) reduced GSR protein levels in the hippocampus and prefrontal cortex, respectively. Interestingly, adult rats treated chronically with the antidepressant fluoxetine exhibited enhanced GSH levels and increased GPx and GSR activity in the hippocampus, both in the absence and presence of stress exposure (Perić, Stanisavljević et al. 2017), suggesting that enhanced GSH levels may contribute to the reversal of depressive-like behaviors. In addition to reductions in the GSH system, nearly all these studies also reported the development of depressive-like or anxiety-like symptoms following chronic stress exposure, suggesting a potential link between alterations in the GSH system and stress-induced psychopathologies.

In agreement with this view, the clinical literature supports the involvement of GSH in psychopathologies such as depression. Namely, the consequence of chronic stress and hyperactivity of the HPA axis is associated with reduced GSH in humans as well as the development of depression. Several magnetic resonance spectroscopy (MRS) studies have reported decreased GSH levels both 
broadly in the cortex (Shungu 2012; Lapidus, Gabbay et al. 2014; Godlewska, Near et al. 2015; Freed, Hollenhorst et al. 2017) and specifically in the prefrontal cortex (Gawryluk, Andreazza et al. 2011) in patients suffering from major depressive disorder (MDD). Reduced gene expression of several antioxidant enzymes, including glutathione synthetase (GS), GPx, and glutathione S-transferases (GST) was also observed in the hippocampus of patients with bipolar disorder (Benes, Matzilevich et al. 2005). Conversely, antidepressant treatments were found to recover altered GSH-related enzyme activities when analyzed in plasma samples of MDD patients (Bilici, Efe et al. 2001) and serum (Atmaca, Tezcan et al. 2004) samples from patients with social phobia, further highlighting the relationship between GSH and depression. Together these data suggest that stress-induced oxidative stress might plausibly contribute to pathophysiological mechanisms leading to depression. Consistent with this hypothesis, increased oxidative stress can lead to a variety of physiological alterations which have been proposed to contribute to the etiology of depression including reduced mitochondrial energy production and function, altered expression of membrane receptors and receptors (such as GABA receptors; (Calvo and González 2016)), reduced neurogenesis, as well as enhanced inflammation and neurodegeneration (reviewed in (Maes, Galecki et al. 2011)), suggesting that therapeutic strategies aiming at restoring GSH levels are worth exploring.

The literature that examines the GSH system in the context of anxiety is less clear. In clinical studies, whole blood analyses have reported both lower (Ozdemir, Selvi et al. 2012) and higher GPx activity levels in individuals with obsessive compulsive disorder compared to healthy controls (Kuloglu, Atmaca et al. 2002a; Kuloglu, Atmaca et al. 2002b); the discrepancy may lie in the differences in ages of the subjects and duration of illness. An important consideration concerns the measurement of GSH and related enzymes - whether these measurements were performed in serum (Ozdemir, Selvi et al. 2012) or in hemolysates (Kuloglu, Atmaca et al. 2002a), may well explain discrepant findings as GSH is primarily located intracellularly (Dringen 2000). In other anxiety conditions, such as in patients suffering from social phobia (Atmaca, Tezcan et al. 2004; Atmaca, Kuloglu et al. 2008) or panic disorder (Kuloglu, Atmaca et al. 2002b), whole blood analyses also reported higher levels of GPx activity in patients than healthy controls (Kuloglu, Atmaca et al. 2002b). In rodent models of anxiety, findings have similarly been reported in both directions. For instance, one study profiled gene 
expression across several brain regions in six inbred mouse strains that differed in their innate anxiety levels and found that the expression patterns of GSR and Glyoxylase 1 (Glo1), correlated positively with anxiety-like behavior in the amygdala and cingulate cortex (Hovatta, Tennant et al. 2005). Glo1 is a detoxification enzyme that uses GSH as a cofactor, while GSR maintains GSH levels in the brain. Surprisingly, when GSR was overexpressed in the cingulate cortex, animals exhibited increased anxiety-like behavior (Hovatta, Tennant et al. 2005). However, another study showed that inhibition of glutamate cysteine ligase (GCL), the rate-limiting enzyme in the synthesis of GSH, impacts the levels of GSH in the brain in parallel to anxiety. Specifically, the study reported that intraperitoneal (i.p.) injection of rats with L-buthionine-(S,R)-sulfoximine (Sibson, Dhankhar et al.), a GCL inhibitor, decreased GSH levels and increased oxidative damage in the amygdala and hippocampus, along with increased anxiety-like behaviors (Salim, Sarraj et al. 2010). Additionally, a mouse strain that was selected based on its high anxiety levels exhibited decreased protein expression of Glo1 in the whole brains compared to a mouse strain selected for its low anxiety, suggesting that deficiencies in the GSH system are linked with anxiety (Krömer, Keßler et al. 2005; Szegö, Janáky et al. 2010).

Altogether, these findings tend to indicate that increased oxidative damage and decreased GSH levels are observed under situations of high energetic demand in the brain such as psychogenic stress. Therefore, strategies aimed at restoring GSH levels and facilitating the neutralization of oxidative damage could represent a new therapeutic option. In this review, we provide several pieces of evidence that highlight the therapeutic potential of enhancing GSH in the brain through nutritional/pharmaceutical interventions to treat stress-induced disorders.

\section{Compounds with potential to modulate brain GSH levels}

Identifying treatments that enhance brain GSH levels may help develop therapies against stress-related neuropsychiatric diseases. In this section, we explore possible methods of increasing GSH levels in the brain.

Although a fraction of dietary GSH can cross the intestinal barrier and enter the blood stream directly, this process is inefficient and most GSH in humans is thought to be synthesized endogenously. Direct supplementation with GSH is a challenging approach, because it can be rapidly degraded by the action 
of gamma-glutamyltransferase (GGT) in the extracellular space (Ballatori, Krance Suzanne et al. 2009), and then either partially hydrolyzed to glutamate and cysteine-glycine peptides or oxidized to form a $\gamma$-glutamyl amino acid (Meister 1991; Inoue 2016). These products are subsequently either degraded or transformed themselves, preventing GSH from reaching the brain in adequate concentrations. In particular, GSH bioavailability appears to be very limited following oral administration (Mischley, Conley et al. 2016). While data from rodents suggests that oral GSH is absorbed through the jejunum (Hagen, Wierzbicka et al. 1990), the human gastrointestinal tract has significantly higher levels of GGT, which may result in GSH recycling rather than absorption (Witschi, Reddy et al. 1992; Zhang, Jay Forman et al. 2005). Accordingly, oral administration of $500 \mathrm{mg}$ of GSH twice daily for 4 weeks did not result in increased levels of GSH or decreased levels of oxidative stress biomarkers in red blood cells in healthy adults (Allen and Bradley 2011). Efforts to enhance the effectiveness of oral GSH administration using liposomal forms have shown some success, with healthy adults exhibiting modest increases in blood and plasma GSH levels, as well as concurrent decreases in blood biomarkers of oxidative stress (Sinha, Sinha et al. 2018) following 2- and 4-week oral administration of 500 and 1000 mg daily doses.

Other routes of delivery, such as intravenous, intranasal, and sublingual administration, have been suggested as possible alternatives to bypass the issue of gastrointestinal GSH metabolism. Intravenous administration of $1200 \mathrm{mg}$ of GSH daily for 4 weeks or $1400 \mathrm{mg}$ of GSH 3 times a week for 4 weeks resulted in a marked improvement in motor scores in Parkinson's patients, though GSH levels in the brain were not measured (Sechi, Deledda et al. 1996; Hauser, Lyons et al. 2009). Intranasal delivery of $200 \mathrm{mg}$ of GSH to Parkinson's patients through a nasal spray increased GSH levels in the brain, as measured by ${ }^{1} \mathrm{H}-\mathrm{MRS} 1 \mathrm{~h}$ after delivery (Mischley, Conley et al. 2016). However, the most recent follow-up of this study only found mild increases in brain GSH levels and decreases of GSH in the blood following 12 weeks of $600 \mathrm{mg}$ GSH daily treatment (Mischley 2017), raising doubts about the efficacy of this route of administration. Finally, sublingual administration of $150 \mathrm{mg}$ of GSH three times daily for 3 weeks significantly increased the ratio of GSH/GSSG compared to oral GSH administration in patients with metabolic syndrome (Schmitt, Vicenzi et al. 2015). 
Given the limited efficiency of GSH supplementation, we review alternative strategies to increase GSH levels in the CNS (Table 1 and 2). There are two main strategies to target GSH: i) providing substrates (or precursors of substrates) involved in the synthesis of GSH (reviewed in section 3.1; Fig. 1 and Table 1) and ii) targeting the activity/expression levels of Nrf2, an important member of the antioxidant response system that regulates the transcription of enzymes involved in the synthesis and recycling of GSH (reviewed in section 3.2; Fig. 1 and Table 2).

The role of redox imbalance as a physiopathological mechanism in neurodegenerative (Niedzielska, Smaga et al. 2016) and metabolic diseases (Ighodaro 2018) has been largely explored in the last decade. Interestingly, chronic stress is a risk factor not only for psychopathologies but also for neurodegenerative disorders (Peña-Bautista, Casas-Fernández et al. 2020) or metabolic disorders (Stefanaki, Pervanidou et al. 2018), among others (further discussed in the conclusions and discussion section). Although comparisons between studies investigating brain disorders of such different nature such as psychiatric disorders or neurodegenerative diseases, or even between brain or non-brain related disorders should be made with caution, the references cited in the next sections (that are not strictly related to psychopathologies) are intended to serve as a reference of the capacity of some promising compounds to raise GSH levels.

\subsection{Enhancing GSH through GSH precursors treatment}

Increasing GSH levels can be theoretically achieved by providing its building blocks (cysteine, glycine and glutamate) or their precursors such as taurine and whey proteins for cysteine, or glutamine for glutamate. Below we review the evidence supporting the hypothesis that increased availability of these precursors may increase GSH levels in the brain (Table 1).

3.1.1 N-acetyl-cysteine. $\mathrm{N}$-acetyl-cysteine (NAC) is the $\mathrm{N}$-acetylated derivative of the amino acid cysteine. Following cellular uptake, NAC is hydrolysed to release cysteine, which is a precursor of GSH and a rate-limiting factor for the synthesis of GSH (Arakawa and Ito 2007; Berk, Malhi et al. 2013). Several studies have found enhanced GSH levels in the brain following NAC treatment. In human 
studies, chronic oral NAC administration (2700 mg daily for six months) enhanced GSH levels in the medial prefrontal cortex as compared to placebo treatment in early psychosis patients (Conus, Seidman et al. 2017). Interestingly, a single intravenous administration $(150 \mathrm{mg} / \mathrm{kg})$ was also shown to increase brain and blood GSH levels in both healthy subjects and patients with Parkinson's disease (Holmay, Terpstra et al. 2013). In another study, chronic oral administration of NAC (6000 mg/day for four weeks) in a group comprising Parkinson`s patients and healthy individuals resulted in higher GSH/GSSG ratio in whole blood compared to pre-treatment levels (Coles, Tuite et al. 2018). Oral (5$25 \mathrm{mg} / \mathrm{kg}$ ) or i.p. (7.5-75 mg/kg) administration of NAC has been shown to increase GSH levels in the hippocampus of mice that cannot synthesize GSH (knockout for EAAC1, an important transporter for glutamate, aspartate and cysteine uptake) (Reyes, Cittolin-Santos et al. 2016).

The anxiolytic and antidepressant properties of NAC have been studied in different model organisms (i.e. zebrafish, mice, rats) and in clinical trials in humans, with encouraging results. In zebrafish, NAC treatment, at concentrations of $0.1-10 \mathrm{mg} / \mathrm{L}$ (provided in the water tank for $10 \mathrm{~min}$ ), prevented acute stress-induced anxiety-like behavior (Mocelin, Herrmann et al. 2015) and, when given at dose of 1 $\mathrm{mg} / \mathrm{L}$ per day for 7 days, reversed the anxiogenic effects and increased ROS induced by chronic unpredictable stress (Mocelin, Marcon et al. 2018). In mice, treatment with NAC, acutely (60-150 $\mathrm{mg} / \mathrm{kg}$ ) or subchronically (10-100 mg/kg i.p for four consecutive days) reduced anxiety and increased social preference (Santos, Herrmann et al. 2017). Interestingly, in another mouse model, even though a single NAC treatment (30-120 mg/kg, i.p.) alleviated the somatic symptoms of nicotine withdrawal (e.g. hyperalgesia), it was not sufficient to reverse the withdrawal-induced increases in anxiety (Bowers, Jackson et al. 2016).

In humans, clinical studies have assessed the effects of NAC treatment on depressive symptoms. A meta-analysis on five double-blind, randomized, placebo-controlled NAC trials (daily dose between 2$3 \mathrm{~g}$ ) for 12-24 weeks, in patients with bipolar disorder or MDD indicated that NAC treatment improves depression scores and functionality scores compared to placebo (Fernandes, Dean et al. 2016). Recently, NAC efficiency was tested in a double-blind, randomized clinical trial in patients with bipolar depression and MDD, who received either placebo or $1.8 \mathrm{~g}$ of NAC per day for 12 weeks. Importantly, NAC treatment was effective in reducing depressive and anxiety symptoms, but only when baseline 
high sensitivity C-reactive protein levels in patients were above $3 \mathrm{mg} / \mathrm{L}$ (Porcu, Urbano et al. 2018). These data suggest that NAC treatment may have higher therapeutic potential in patients in which depressive and anxiety symptoms coexist with higher levels of inflammation.

In addition, other studies have evaluated the potential therapeutic efficacy of NAC treatment in preclinical models and clinical trials (as adjunctive treatment) for other psychiatric conditions, such as autism (Wink, Adams et al. 2016), schizophrenia (Herrmann, Benvenutti et al. 2014; Conus, Seidman et al. 2017; Sepehrmanesh, Heidary et al. 2018), obsessive-compulsive spectrum disorders and Tourette syndrome in humans (Hirschtritt, Bloch et al. 2017), with promising results particularly in patients with chronic schizophrenia (Sepehrmanesh, Heidary et al. 2018). Therefore, the reviewed evidence supports the view that NAC could be effectively used to increase brain GSH levels and improve the symptoms of a broad range of psychiatric disorders.

3.1.2 Glycine. Glycine is a simple amino acid that is an essential substrate for the synthesis of several biomolecules such as creatine, purines, porphyrins, and GSH (Hall 1998; Razak, Begum et al. 2017). Glycine accounts for $11.5 \%$ of the total amino acid content in the human body and deficiencies can lead to impairments in growth, immune response, and nutrient metabolism (Razak, Begum et al. 2017). While glycine can be synthesized in the body from threonine, serine, choline, and hydroxyproline, this endogenous synthesis is insufficient to meet metabolic demands for most mammals (including humans) and additional glycine must be obtained from the diet ( $\mathrm{Wu}, \mathrm{Wu}$ et al. 2013). In addition to its role in metabolite synthesis, glycine is crucially involved in a variety of biological processes, including extracellular structural proteins synthesis, conjugation of bile acids, cytokine production and regulation, and its function as a neurotransmitter to regulate food intake, behavior, and whole-body homeostasis (Wang, Wu et al. 2013).

For the synthesis of GSH, glycine is the second rate-limiting substrate, after cysteine (see Box 1 and Fig. 1). While most research has focused on increasing cysteine levels in the brain in order to drive GSH synthesis, glycine supplementation alone or in combination with cysteine-enhancing compounds are gaining attention for their ability to enhance GSH. Treatment of diabetic patients with an oral combination of NAC $(0.81 \mathrm{mmol})$ and glycine $(1.33 \mathrm{mmol})$ for 14 days restored GSH synthesis and 
concentrations to that of control subjects (Sekhar, McKay et al. 2011). In a separate study, oral treatment of elderly subjects with both NAC $(0.81 \mathrm{mmol})$ and glycine $(1.33 \mathrm{mmol})$ for 14 days restored low baseline levels of cysteine, glycine, and GSH/GSSH ratio in the red blood cells to that of young untreated subjects (Sekhar, Patel et al. 2011). In rodents, intragastric administration of glycine $(1.5 \mathrm{~g} / \mathrm{kg} /$ day for 3 days) was sufficient to increase myocardial GSH content following a severe burn (Zhang, Lv et al. 2013). So far, most research using glycine treatments have been performed in patient or elderly populations and while a high-dose regimen of oral glycine treatment (10g/day for 14 days) was shown to increase glycine levels in the brain in healthy men (Kaufman, Prescot et al. 2009), it is not yet known whether glycine supplementation will increase brain GSH levels in a healthy population. In the field of psychiatry, glycine supplementation has not traditionally been used as treatments for stress-induced pathologies. Instead, glycine has been used in combination with antipsychotic therapies to combat the negative symptoms of schizophrenia with mixed results (Aleman, Lincoln et al. 2017), though effectiveness may depend on individual plasma levels of glycine (Heresco-Levy, Javitt et al. 1996). The preclinical literature, however, has several reports that examined the effect of glycine on anxiety-like behavior in healthy adult rodents (Schmitt, Coelho et al. 1995; Dolu 2007). Here, both systemic (250-1250 mg/kg i.p. 30 min prior to testing; Dolu, 2007) or local microinjection (40-80 nmol in the periaqueductal grey, 10 min prior to testing; (Schmitt, Coelho et al. 1995)) of glycine resulted in dose-dependent increases in anxiety-like behavior. While these findings appear to support those studies reporting anxiogenic associations with GSH (Kuloglu, Atmaca et al. 2002a; Atmaca, Tezcan et al. 2004; Hovatta, Tennant et al. 2005; Atmaca, Kuloglu et al. 2008), it is important to note that GSH levels were not measured in these studies. Moreover, the anxiogenic properties of glycine administration were attributed to glycine's functions as a neurotransmitter to activate N-methyl-D-aspartate (NMDA) receptors (Mayer, Benveniste et al. 1992), rather than any potential GSH-enhancing actions. Taken together, these data suggest that glycine supplementation alone may prove challenging for targeted GSH-enhancement, as its other functions, particularly in the brain, may exert opposite or undesirable effects. Importantly, the effects of combined administration of glycine with other GSH-enhancing compounds, such as NAC, on stress-induced behaviors have yet to be evaluated. As such therapies have 
been shown to enhance GSH levels, understanding the effects on behavior will clarify the suitability of glycine as an adjuvant alongside other compounds.

3.1.3 Taurine. Taurine, a 2-aminoethylsulfonic acid, is the most abundant free amino acid in nearly every tissue in the body, including the brain (Ripps and Shen 2012). In the brain, taurine exhibits developmental regulation, with high concentrations in the neonatal brain that decrease to a third or a quarter (depending on the species) (Huxtable 1989; Sturman 1993). Taurine is mainly absorbed through dietary sources such as eggs, meat, and seafood, and a limited amount is endogenously synthesized in the liver, brain, heart, and lungs (Lambert, Kristensen et al. 2015). Importantly, taurine has been reported to exert numerous physiological functions including osmoregulation, neuromodulation and membrane stabilization (Huxtable 1992). Moreover, taurine has been widely studied for its antioxidant actions. On its own, taurine has the ability to scavenge ROS, reduce the production of lipid peroxidation end-products, and stabilize cell membranes (Huxtable 1992).

Importantly, taurine supplementation has been shown to enhance GSH levels, including in the brain. For instance, in an age-related disease model, animals fed with $2.5 \% \mathrm{w} / \mathrm{w}$ taurine in their daily chow for 2 months exhibited significantly elevated levels of GSH alongside reduced levels of lipid peroxidation products in whole brain homogenates (Aydın, Çoban et al. 2016). Taurine treatment (10$40 \mathrm{mg} / \mathrm{kg}$ for 45 days) can also induce GPx activity and prevent carbon tetrachloride-induced lipid peroxidation (Vohra and Hui 2001). Moreover, a high dose taurine treatment (400 mg/kg by oral gavage for 9 weeks; (Tu, Chang et al. 2018)) was able to increase GSH levels in the whole brain homogenate of rats exposed to D-galactose (Tu, Chang et al. 2018). Notably, most studies that reported enhanced GSH in the brain following taurine treatment were performed under a chronic regimen and used in agerelated disease models. Such positive effects of taurine on GSH levels may be explained by the fact that cysteine is the essential precursor to both metabolites, whereby taurine supplementation may drive the metabolism of cysteine towards GSH synthesis. In this context, it is important to note that GSH and GSSG were shown to modulate $\mathrm{K}^{+}$and glutamate-evoked release of taurine in acute hippocampal slices (Janáky, Shaw et al. 2008). High concentrations of GSH and GSSG increased taurine release while low 
concentrations attenuated it (Janáky, Shaw et al. 2008), suggesting that the relationship between GSH and taurine may be bidirectional.

In stress and stress-related pathologies, taurine supplementation has been shown to improve behavioral outcomes, though the mechanism underlying this aspect remains largely unaddressed. In zebrafish exposed to acute chemical stress, those acutely pretreated with taurine $(42 \mathrm{mg} / \mathrm{L}$ in the water for $1 \mathrm{~h})$ exhibited decreased anxiety-like behavior as well as reduced whole brain protein carbonylation (a type of protein oxidation that can be provoked by ROS) and enhanced SOD activity (Mezzomo, Fontana et al. 2019). Following chronic unpredictable stress in adult rats, chronic taurine treatment (200 $\mathrm{mg}$ or 500 mg i.p. daily for 28 days) reduced expression of stress-induced anhedonia and novelty-induced anxiety (Wu, Ren et al. 2017). Rats treated during adolescence with a high dose of taurine (2000 mg/kg/day in the drinking water for 10 days) exhibited a reversal of cognitive deficits induced by prenatal stress (Jia, Sun et al. 2016). Moreover, chronic taurine supplementation (45 mmol taurine $/ \mathrm{kg}$ diet for 4 weeks) induced antidepressant-like effects in adult male rats.

In addition to the antidepressant effects of taurine treatments following stress, several studies have reported anxiolytic effects following acute taurine treatment in the absence of stress. In zebrafish, brief taurine treatment (42-400 $\mathrm{mg} / \mathrm{L}$ in the water for $1 \mathrm{~h}$ ) decreased anxiety-like behavior in a light-dark test (Mezzomo, Silveira et al. 2016). In adult rats, taurine treatment (42, $126 \mathrm{mg} / \mathrm{kg}$ i.p. $30 \mathrm{~min}$ prior to testing) increased social interaction and decreased anxiety-like behavior in similar levels as a diazepam treatment (Kong, Chen et al. 2006). Similar anxiolytic effects were reported in adult mice acutely treated with taurine (60 mg/kg orally $40 \mathrm{~min}$ prior to testing) (Chen, Kong et al. 2004). Interestingly, when taurine was administered for 7 days, high doses $(60 \mathrm{mg} / \mathrm{kg})$ were no longer effective, but lower doses $(2.5 \mathrm{mg} / \mathrm{kg}$ ) were able to reduce anxiety-like behavior (Chen, Kong et al. 2004). Similarly, an acute injection of taurine ( $43 \mathrm{mg} / \mathrm{g}$ s.c. 15 min prior to testing) decreased anxiety-like behavior in the open field and elevated plus maze, while chronic administration of taurine $(0.05 \%$ in the drinking water for 4 weeks) was anxiogenic (Idrissi, Boukarrou et al. 2009), suggesting an inverted U-shaped curve for efficacy. Taken together, there is strong support for beneficial effects of taurine in anxiety-like behaviors in the preclinical literature, though a fine tuning of dose and regimen may be crucial for obtaining the maximal effects. While data for taurine in anxious humans is scarce, a recent study found 
that trait anxiety was negatively associated with taurine levels in the human ventral striatum (Strasser, Xin et al. 2019), suggesting that taurine may have clinical relevance in human anxiety.

3.1.4 Whey proteins. Dairy products, whey proteins (mainly $\beta$-lactoglobulin, $\alpha$-lactalbumin, immunoglobulins and serum albumin) and their concentrates are rich sources of amino acids, such as cysteine and methionine, which can provide key substrates for GSH synthesis (Graf, Egert et al. 2011; Falkowski, Maciejczyk et al. 2018). Self-reported routine dairy intake in older adults has been shown to be associated with higher brain GSH levels (Choi, Lee et al. 2014). Moreover, whey proteins have been described to exhibit radical scavenging activity (Corrochano, Buckin et al. 2018) and to decrease oxidative stress (Shertzer, Krishan et al. 2013; Choi, Lee et al. 2014).

Several studies indicate that supplementation with whey protein concentrates can impact the redox status in rodents. For instance, supplementation with whey proteins in rats for 28 days $(1 \mathrm{~g} / \mathrm{kg} / \mathrm{day})$ decreased markers of oxidative damage in peripheral tissues and in the brain, although GSH levels were found increased only in peripheral tissues and not in the brain (Kerasioti, Stagos et al. 2018). Recently, the antioxidant potential of Immunocal ${ }^{\circledR}$, a whey protein supplement enriched in cystine-donor proteins has been studied. Cystine, the oxidized form of cysteine, is resistant to proteolysis and can be transported via the blood flow to target organs and tissues, where it is absorbed by cells and reduced to two cysteine molecules (Winter, Ross et al. 2017). Rat cerebellar granule neurons treated with a medium containing $3.3 \%$ Immunocal $^{\circledR}$ for $24 \mathrm{~h}$ were protected from the drop in GSH induced by a pro-apoptotic drug termed HA14-1 (Zimmermann, Loucks et al. 2007; Winter, Ross et al. 2017). Immunocal ${ }^{\circledR}$ also protected a cell line (NSC-34 cells) from $\mathrm{H}_{2} \mathrm{O}_{2}$-induced cell death (Winter, Ross et al. 2017). In vivo, Immunocal ${ }^{\circledR}$ supplementation in drinking water $(33 \mathrm{mg} / \mathrm{mL})$ for six weeks resulted in increased brain GSH concentration in the GFAP.HMOX1 mouse model of schizophrenia (mice expressing human oxygenase 1 in astrocytes) (Song, Tavitian et al. 2017). Moreover, treatment with Immunocal ${ }^{\circledR}$ (ad libitum access to a solution containing $3.3 \%$ Immunocal $^{\circledR}$ in drinking water, starting at postnatal day 60) resulted in delayed disease onset and progression in a mouse model of amyotrophic lateral sclerosis (Ross, Winter et al. 2014). Finally, a double-blind, placebo-controlled pilot clinical study treating Parkinson's' disease patients with $20 \mathrm{~g} /$ day Immunocal $^{\circledR}$ showed that the treatment significantly 
increased plasma GSH in Parkinson's patients but not in the control group. However, there were no significant changes in the clinical outcomes measured in the study following supplementation (Tosukhowong, Boonla et al. 2016).

In mice, supplementation with $\alpha$-lactalbumin (in food at a concentration of $181 \mathrm{~g} / \mathrm{kg}$ of diet, for three weeks), one of the most abundant whey proteins, prevented anxiety-like behavior induced by exposure to short photoperiods in mice (Otsuka, Goda et al. 2015). Peptides derived from whey or milk proteins can also exert anxiolytic effects in rodents and humans. $\beta$-Lactotensin, a tetrapeptide (His-Ile-Arg-Leu) derived from bovine milk $\beta$-lactoglobulin, exhibited anxiolytic properties in $\mathrm{C} 57 \mathrm{BL} / 6$ mice at concentrations of 1-3 mg/kg, i.p. and at a dose of 3-10 mg/kg in Deutchland, Denken, and Yoken-strain (ddY) (Shirendeb, Reddy et al.) mice (Hou, Suzuki et al. 2011). Oral administration of $\beta$-Lactotensin (3-10 mg/kg) also resulted in similar effects (Hou, Suzuki et al. 2011). Another study reported anxiolytic effects of bacterial digests of $\beta$-lactoglobulin, a dipeptide (Methionine-Histidine) and a tripeptide (Methionine-Lysine-Glycine), named Wheylin-1 and Wheylin-2, respectively, at doses of $0.3-1$ and 3 $\mathrm{mg} / \mathrm{kg}$ i.p in ddY mice (Yamada, Mizushige et al. 2014). In humans, a double-blind, placebo-controlled, randomized study, recruiting high anxious individuals was conducted, in which participants received either normal yoghurt, or yoghurt containing bioactive components of milk ( $\alpha$-lactalbumin, caseinderived tripeptides and vitamin B12, B6 and folacin) (Jaatinen, Korpela et al. 2014). Results showed that participants who received the yoghurt containing the bioactive compounds for 4 weeks, had reduced anxiety scores, and reported higher feelings of vigor and lower feelings of inefficiency (Jaatinen, Korpela et al. 2014). Thus, it has been suggested that daily intake of yoghurt enriched with bioactive components may aid in stress coping. However, it remains unclear whether these bioactive peptides and proteins promote GSH synthesis as cysteine/cystine donors, or if they act via distinct mechanisms.

3.1.5 Glutamine. In the brain, glutamine is an abundant amino acid with an important role as a precursor for glutamate, aspartate and gamma-aminobutyric acid (GABA) neurotransmitter synthesis, as well as a key participant in the recycling of neurotransmitters (Albrecht, Sidoryk-Węgrzynowicz et al. 2010). As a precursor of glutamate, glutamine is also an indirect precursor of GSH, and has a protective role against oxidant injury. For instance, in hyperoxic conditions, glutamine (1-4 mM concentrations tested, 
the most effective dose is $2 \mathrm{mM}$ ) prevented the loss of ATP, preserved mitochondrial membrane potential, protected mitochondria from damage and increased $\mathrm{O}_{2}$ consumption rate and GSH content (Ahmad, White et al. 2001). Glutamine $(32-128 \mu \mathrm{M})$ has also shown a protective effect against oxidative stress through the inhibition of PI3K/Akt signalling pathway in a Parkinson Disease cell model (Zhao, Wang et al. 2019). Interestingly, GSH can also supply glutamate when the import of gliaderived glutamine into neurons is blocked (by the inhibition of System A transporter) (Sedlak, Paul et al. 2019).

It has been reported that glutamine levels in the brain are tightly regulated to allow normal brain function and disturbances in glutamine metabolism and/or transport have been associated with different brain pathological conditions (Albrecht, Sidoryk-Węgrzynowicz et al. 2010). In patients with MDD, glutamine levels and the glutamine/glutamate ratio were significantly lower than control subjects, suggesting abnormalities in the glutamate-glutamine cycle in depression (Umehara, Numata et al. 2017). More evidence about glutamine/glutamate impairment in psychiatric disorders has been acquired from studies in mice exposed to chronic unpredictable stress. In particular, these animals showed both decreased glutamine levels and glutamine/glutamate ratio (Ding, Li et al. 2017). In addition, social isolation produced a decrease in glutamine levels and induced oxidative stress in the rat hippocampus (Shao, Yan et al. 2015). Interestingly, when GSH levels decreased in a mouse model of GSH deficiency induced by knockout of the GCL modulatory subunit (Gclm), the concentration of glutamine and glutamine/glutamate ratio in the frontal cortex increased. This was likely caused by the inability to use glutamate for the production of GSH, which may have resulted to alterations in the expression levels of enzymes involved in the glutamate-glutamine cycle such as glutamine synthetase. Although there was no significant relationship between social isolation stress and GSH deficiency in this study, isolated mice displayed a larger glutamine/glutamate relative to those in group housing (Corcoba, Gruetter et al. 2017).

Studies examining the effect of glutamine supplementation in stress or anxiety are scarce. However, treatment of young rats (postnatal stage P7-27) with glutamine via gavage $(200,500$ or $750 \mathrm{mg} / \mathrm{kg} /$ day), resulted in reduced anxiety-like behavior and microglial activation (de Lima, Francisco et al. 2017). Notably, several reviews raise questions about the positive action of glutamine, highlighting the need 
to pay attention to the suitable doses and conditions of use of glutamine to avoid toxic effects (Smedberg and Wernerman 2016; Wernerman 2017).

\subsection{Enhancing GSH through Nrf2 activation}

While supplementation with precursors of GSH are one avenue for enhancing brain GSH levels, targeted expression of GSH regulation is another possibility. As previously mentioned, Nrf2 regulates the expression of a number of antioxidant enzymes and as well as enzymes critically involved in the synthesis, maintenance and regeneration of GSH such as $G C L, G S T, G P x$ and $G S R$ as well as G6PD (that provides the NADPH necessary for the action of GSR) and SLC7A11 (a cystine/glutamate transporter necessary for the uptake of GSH precursors) (Itoh, Chiba et al. 1997; Hayes, Chanas et al. 2000; Harvey, Thimmulappa et al. 2009; Gorrini, Harris et al. 2013). Thus, Nrf2 maintains intracellular GSH levels through coordinated production, utilization, and regeneration of GSH according to cellular needs. Activation of Nrf2 as a means to enhance GSH under oxidative stress has been gaining attention as a potential therapeutic target (Chen and Kunsch 2004). Indeed, the direct overexpression of the Nrf2 gene enhanced GSH levels in cortical cultures and protected neurons from insults and oxidative stress (Shih, Johnson et al. 2003; Narasimhan, Mahimainathan et al. 2011), further supporting Nrf2 activation as a viable target for GSH modulation.

Under basal, homeostatic conditions, Nrf2 is bound in the cytosol and its actions are repressed by Kelchlike ECH-associated protein 1 (Keap1), a redox-sensitive E3 ubiquitin ligase substrate adaptor (Itoh, Wakabayashi et al. 1999). In the absence of oxidative stress, Nrf2 is degraded by Keap1-mediated ubiquitination (Keum 2012; Canning, Sorrell et al. 2015) (Figure 1). Upon exposure to oxidative stress, Keap1 is oxidized at reactive cysteine residues, resulting in Nrf2 stabilization and translocation to the nucleus. In the nucleus, Nrf2 modulates gene expression by binding to the Antioxidant Response Elements (ARE) in the regulatory regions of antioxidant genes, including GCL, GST, GPX and GSR (Dinkova-Kostova, Holtzclaw et al. 2002; Itoh, Wakabayashi et al. 2003; Bryan, Olayanju et al. 2013; Baird, Swift et al. 2014) (Fig. 1). Nrf2 itself can undergo posttranslational modifications, including ubiquitination, acetylation, and phosphorylation by a number of enzymes that each affect Nrf2's function in a specific manner (Bryan, Olayanju et al. 2013). Finally, the efficient degradation of Nrf2 
occurs by Keap1-mediated ubiquitination (Keum 2012; Canning, Sorrell et al. 2015) (Fig. 1). Thus, there are several possible routes to target $\mathrm{Nrf} 2$ activation.

One possibility to activate $\mathrm{Nrf} 2$ is to enhance its binding to the ARE sequences on its downstream targets. Acetyltransferase complexes such as $\mathrm{p} 300 / \mathrm{CBP}$ promote the acetylation on Nrf2 and enhance subsequent binding to the ARE sequences in the DNA (Katoh, Itoh et al. 2001; Sun, Chin et al. 2009). Another strategy to boost Nrf2 activity is to target its binding to Keap1 via phosphorylation of Nrf2. Several kinases such PKC (Huang, Nguyen et al. 2000), PI3K, PERK (Cullinan, Zhang et al. 2003), MAPK, ERK and JNK have been shown to phosphorylate Nrf2, weaken its binding to Keap1, and promote antioxidant gene expression (Keum, Owuor et al. 2003; Keum, Yu et al. 2006). However, these families of acetyltransferases and kinases have a wide range of molecular targets. Therefore, pharmacological manipulation of these proteins in order to specifically enhance Nrf2 activity would be challenging.

In terms of Nrf2 specificity, two additional strategies have been gaining attention due to their interesting GSH-enhancing potential. The first strategy is targeting specific binding sites between Nrf2 and Keap1. The sequestration of Nrf2 to Keap1 has been shown to depend primarily on cysteine residues that reside on Keap1 (Zhang and Hannink 2003; Dinkova-Kostova, Kostov et al. 2017). Compounds, such as sulforaphane, dimethyl fumarate, curcumin and trehalose that modify these cysteine residues can block Keap1-Nrf2 signaling, allowing Nrf2 accumulation, translocation of Nrf2 to the nucleus, and subsequent activation of GSH-related gene expression (Dinkova-Kostova, Kostov et al. 2017). Interestingly, many of these compounds such as sulforaphane and curcumin have been derived from plant extracts (phytochemicals) (Lee, Jo et al. 2014). These compounds may activate transcriptional programs that offer cellular protection against oxidative stress. Furthermore, they can also improve energy metabolism, protect against aggregates of misfolded proteins and inflammatory stress (Lee, Jo et al. 2014). The second strategy focuses on enhancing Nrf2 levels through targeted inhibition of the proteasome responsible for its degradation. Melatonin has been shown to enhance Nrf2 levels via inhibition of its proteasome (Abd El Mohsen, Iravani et al. 2005; Park, Woo et al. 2014). Thus, despite the tight regulation of Nrf2 by Keap1, there are several ways to modulate Nrf2 activation and, 
consequently, increase GSH levels in the brain. Below we elaborate on the compounds employing these two Nrf2 activating approaches (Table 2).

\subsubsection{Sulforaphane}

Sulforaphane is an organosulfur compound that can be extracted from a variety of cruciferous vegetables including broccoli, Brussels sprouts, cauliflower, and cabbage (Shapiro, Fahey et al. 2001). Sulforaphane is readily absorbed in humans and is rapidly eliminated. More than $70 \%$ of an administered dose of sulforaphane can be recovered as thiol conjugates in the urine and its half-life is a few hours. The most characteristic feature of sulforaphane is its high chemical reactivity due to the electrophilicity of the central carbon of the isothiocyanate group. The isothiocyanate group reacts readily with sulfur-, nitrogen-, and oxygen-centered nucleophiles [reviewed in (Di Pasqua, Chung et al. 2011; Zheng, Tao et al. 2012)]. Upon entering the cell, sulforaphane chemically reacts with the reactive cysteine residues on Keap1 (Itoh, Wakabayashi et al. 1999; Dinkova-Kostova, Holtzclaw et al. 2005; Dinkova-Kostova, Kostov et al. 2017); and is confirmed to specifically target cysteine C151 (McMahon, Lamont et al. 2010). In vitro studies found that incubation with either 5 or $10 \mu \mathrm{M}$ Sulforaphane for $48 \mathrm{~h}$ enhanced astrocytic release of GSH levels 2.4-fold above controls, without inducing extracellular increases of cytotoxic by-products (Steele, Fuller et al. 2013). Moreover, primary rat astrocytes transiently $(1-4 \mathrm{~h})$ stimulated with $10 \mu \mathrm{M}$ sulforaphane exhibited significantly enhanced GSH levels that persisted up to $24 \mathrm{~h}$ later (Bergström, Andersson et al. 2011). Similarly, incubation of striatal cultures with $1 \mu \mathrm{M}$ of sulforaphane significantly increased GCL protein and GSH levels after 12 and $24 \mathrm{~h}$ respectively (Mizuno, Kume et al. 2011). Repeated sulforaphane treatment ( $4 \mathrm{~h}$ incubations of $10 \mu \mathrm{M}$ sulforaphane for 4 consecutive days) led to persistent protection against superoxide and enhanced GSH levels (Bergström, Andersson et al. 2011). These results suggest that sulforaphane has the capacity to enhance GSH levels in neurons and astrocytes in a neuroprotective manner. More recently, a study found that oral sulforaphane administration (100 $\mu$ mol for 1 week) enhanced both blood and hippocampal GSH levels in healthy human subjects (Sedlak, Nucifora et al. 2017). Interestingly, while GSH levels were not significantly enhanced in the anterior cingulate cortex or thalamus, thalamic GSH values significantly correlated with blood GSH levels (Sedlak, Nucifora et al. 
2017), suggesting that peripheral GSH levels may be a marker of brain GSH content outside of sulforaphane treatment.

While the majority of studies have focused on the anticarcinogenic effects of sulforaphane, recent attention has turned to the antioxidant effects of sulforaphane following stress exposure and in stressrelated pathologies. In adult male mice, pretreatment with sulforaphane (10 mg/kg i.p. for 10 days) 30 min prior to social defeat reduced the stress-induced depressive-like behaviors of social avoidance and decreased sucrose preference (Yao, Zhang et al. 2016). While GSH levels were not measured in this study, protein levels of Nrf2 and Keap1 were increased in the hippocampus and prefrontal cortex following sulforaphane treatment (Yao, Zhang et al. 2016). In another study, pretreatment of adult mice with sulforaphane (10 mg/kg i.p. for 14 days) $30 \mathrm{~min}$ prior to chronic mild stress prevented the onset of depressive-like behaviors in the forced swim test and tail suspension test and decreased anxiety-like behaviors measured in the open field and novelty-suppressed feeding test ( $\mathrm{Wu}, \mathrm{Gao}$ et al. 2016). A similar sulforaphane treatment (10 days of $10 \mathrm{mg} / \mathrm{kg}$ i.p.) was also recently shown to diminish anxietyand depressive-like behaviors in response to neuropathic pain (Ferreira-Chamorro, Redondo et al. 2018). Interestingly, treatment with sulforaphane in the absence of stress also had antidepressant and anxiolytic effects, as treated mice exhibited reduced immobility times in the forced swim and tail suspension tests, spent more time in the center of an open field, and reduced latency to feeding in the novelty-suppressed feeding test (Wu, Gao et al. 2016). Together, these studies point to the capacity of sulforaphane to function both as a prophylactic against stress-induced behavioral changes and as a positive modulator in healthy animals.

\subsubsection{Dimethyl fumarate}

Dimethyl fumarate (DMF) is a fumarate ester that has been recently developed and formulated for the treatment of relapse-remitting multiple sclerosis (Sheremata, Brown et al. 2015). Similar to sulforaphane, DMF is considered a classical activator of Nrf2, as it modifies the cysteine residue on Keap1, resulting in stabilization of Nrf2, subsequent translocation to the nucleus and activation of ARE targets to reduce oxidative stress (Linker, Lee et al. 2011). Pre-treatment with DMF (10 $\mu \mathrm{M}$, for $24 \mathrm{~h}$ ) in hippocampal neurons or primary cortical neurons resulted in higher levels of GSH and protection 
against glutamate-induced toxicity (Albrecht, Bouchachia et al. 2012). Similarly, oral DMF administration for 4 days $(80 \mathrm{mg} / \mathrm{kg})$ prevented the traumatic brain injury-induced depletion of GSH in mice (Krämer, Grob et al. 2017). Moreover, the DMF-induced GSH increase may be, in part, due to increased recycling of GSH via reduction of GSSG to GSH by GSR, which is a target of Nrf2 (Hoffmann, Dietrich et al. 2017). Unlike sulforaphane, however, DMF also binds cysteine residues on reduced GSH, resulting in GSH depletion and activation of HO-1 (Lehmann, Listopad et al. 2007). Currently, most studies have focused on preclinical and clinical studies of multiple sclerosis and psoriasis, without examination of potential anxiolytic or antidepressant capacities. However, a recent study has found that DMF treatment ( $25 \mathrm{mg} / \mathrm{kg}$ orally $1 \mathrm{~h}$ before each stress exposure) in mice exposed to chronic unpredictable stress for 8 weeks prevented the stress-induced increase in depression-like behavior, as well as the stress-induced decrease in hippocampal GSH levels (Abd El-Fattah, Fahim et al. 2018).

\subsubsection{Curcumin}

Curcumin, a natural polyphenolic compound extract from Curcuma longa, has been shown to exert a variety of beneficial effects, including anti-inflammatory, anti-tumor, immunomodulatory and neuroprotective activities (Venigalla, Gyengesi et al. 2015; Daverey and Agrawal 2016; Daverey and Agrawal 2018). Curcumin is, in addition, a potent antioxidant and ROS scavenger (reviewed in (PulidoMoran, Moreno-Fernandez et al. 2016)). Evidence indicates that the pleiotropic effects of curcumin are dependent on its capacity of interacting and regulating multiple molecular targets, including nuclear

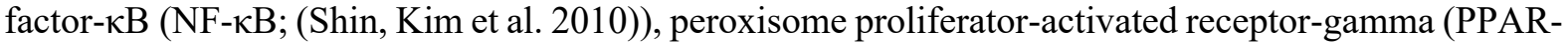
$\gamma$; (Chen and $\mathrm{Xu} 2005)$ ), and Nrf2 (Yang, Zhang et al. 2009). In its interactions with Nrf2, curcumin is reported to inactivate the Keap1-Nrf2 complex, promoting Nrf2 translocation to the nucleus and activation of downstream targets (Balogun, Hoque et al. 2003; Yang, Zhang et al. 2009). The expression or activity of GCL, a Nrf2-target gene and the rate-limiting enzyme in the synthesis of GSH (Lavoie, Chen et al. 2009), is increased by the treatment with curcumin both in vitro, in cultured neurons and astrocytes (Lavoie, Chen et al. 2009) and in vivo, in a traumatic brain injury model (Dong, Yang et al. 2018). 
Numerous in vivo studies have also highlighted the capacity of curcumin to restore the decreased brain GSH levels following exposure to neurotoxic compounds including rotenone (Cui, Xin et al. 2015; Khatri and Juvekar 2016), BSO (Jagatha, Mythri et al. 2008), the neurotoxic agent 1-methyl-4-phenyl1,2,3,6-tetrahydropyridine (MPTP) (Jayaraj, Elangovan et al. 2014) and the mitochondrial inhibitor 3NP (Sandhir, Yadav et al. 2014). More recently, i.p. administration of $40 \mathrm{mg} / \mathrm{kg}$ curcumin for 5 weeks prevented depressive-like behaviors following exposure to chronic mild unpredictable stress (Fan, Song et al. 2018). Dietary curcumin (1.5\% in a global $18 \%$ protein chow) exposure for 5 days increased resilience in mice to the depressive-like effects of social defeat (Aubry, Khandaker et al. 2019). Oral administration of curcumin (10 and $20 \mathrm{mg} / \mathrm{kg}$ orally) for 21 days rescued cognitive and neuronal impairments induced by chronic restraint stress (Xu, Lin et al. 2009). Oral administration of curcumin at 50 or $100 \mathrm{mg} / \mathrm{kg} /$ day also decreased anxiety in ovariectomized female rats (Da Silva Morrone, Schnorr et al. 2016) together with increased levels of non-enzymatic antioxidant and decreased oxidative damage in the brain. Finally, in a randomized, double-blind, placebo-controlled study, individuals with MDD were treated daily with 500 or $1000 \mathrm{mg}$ of patented curcumin (BCM-95) for 12 weeks. Treatment at either dose was associated with a significant reduction in self-reported depressive and anxiety scores (Lopresti and Drummond 2017).

\subsubsection{Melatonin}

Melatonin is a hormone derived from tryptophan and the main product of the pineal gland. While classically associated with sleep and circadian rhythm (Bonnefont-Rousselot and Collin 2010), melatonin also has important antioxidant properties via ROS scavenging and activation of antioxidant enzymes (Ding, Wang et al. 2014) through inhibition of Nrf2 proteasomal degradation (Abd El Mohsen, Iravani et al. 2005; Park, Woo et al. 2014). In the rat brain, melatonin has been shown to stimulate GPx activity (Barlow-Walden, Reiter et al. 1995; Baydaş, Erçel et al. 2001) and to increase cellular levels of Nrf2 following oxidative stress exposure (Negi, Kumar et al. 2010; Wang, Liu et al. 2012). Preclinical studies found that concurrent treatment with melatonin can prevent stress-induced oxidative stress. For instance, in lipopolysaccharides (LPS)-exposed mice, melatonin treatment prevented LPS-induced increases in lipid peroxidation and restored GSH and BDNF levels in the hippocampus (Taniguti, 
Ferreira et al. 2018). In adult rats chronically exposed to ethanol, concurrent treatment with melatonin (10 mg/kg i.p. for 45 days) decreased lipid peroxidation and restored GSH levels in the hippocampus and cortex compared to ethanol exposure alone (Baydas and Tuzcu 2005). Similarly, adult mice treated with melatonin ( $20 \mathrm{mg} / \mathrm{kg}$ orally for 13 days) were protected against the effects of ethanol and restraint stress, exhibiting similar levels of ROS and GSH in the hippocampus as unstressed controls (Rajput, Jangra et al. 2017). Melatonin treatment has also been reported to have antidepressant-like effects. For instance, melatonin treatment $(10 \mathrm{mg} / \mathrm{kg}$ i.p. for 14 days) alleviated depressive-like symptoms following exposure to chronic unpredictable stress (Sun, Wang et al. 2017), dexamethasone (Ruksee, Tongjaroenbuangam et al. 2014), and LPS (Taniguti, Ferreira et al. 2018) in rats and mice. Melatonin administration also alleviated anxiety and depressive-like phenotypes in a transgenic mouse model of Alzheimer's disease (Nie, Wei et al. 2017).

\subsubsection{Trehalose}

Trehalose is a naturally-occurring dissacharide with antioxidant properties, which has been shown to regulate the Keap1-Nrf2 pathway (He, Wang et al. 2014; Mizunoe, Kobayashi et al. 2018; Tang, Liu et al. 2019). Trehalose increases phosphorylation of p62 in serine residue 351, which, in turn, increases nuclear translocation of Nrf2 (Mizunoe, Kobayashi et al. 2018). In contrast, trehalose has been shown to ameliorate the cadmium-induced oxidative stress in the brain by decreasing nuclear translocation of Nrf2 (Tang, Liu et al. 2019). In human mutated tau overexpressing mice, 2.5 months of trehalose treatment ( $1 \%$ in the drinking water) increased GSH levels in the striatum (Rodríguez-Navarro, Rodríguez et al. 2010). In a study using mice of 25 months of age, trehalose treatment ( $2 \%$ in the drinking water for 26 days) resulted to increased Nrf2 expression and improved rotarod performance in male mice (Berry, Marconi et al. 2020). Moreover, trehalose treatment ameliorated manganese-induced mitochondrial dysfunction and ROS production, while it decreased mitochondrial damage by increasing mitophagy (Liu, Jing et al. 2019). Finally, trehalose has successfully improved cognition in a mouse model of Alzheimer`s disease ( $0.1 \mathrm{ml} / 10 \mathrm{~g}$ bodyweight, p.o. for 31 days) (Portbury, Hare et al. 2017). These data, in combination with the fact that trehalose is generally considered safe for use in humans 
and rodents, suggest that trehalose may have therapeutic potential in stress-induced psychopathologies (Richards, Krakowka et al. 2002; Liu, Zhang et al. 2013).

\section{Alternative strategies to increase glutathione levels}

Apart from the main strategies to increase GSH levels through precursor supplementation or activation of Nrf2 pathway, there is substantial evidence that shows the ability of other antioxidants to increase or rescue GSH levels under conditions of oxidative stress. Ergothioneine, L-carnitine, and puerarin are discussed below, as novel possibilities for therapeutic applications. While the exact mechanism of action for some of these antioxidants is not yet well characterized, we include this section since they have been described as positive effectors that protect against oxidative stress damage and impairments in several brain disorders.

4.1 Ergothioneine. Ergothioneine is a naturally occurring amino acid that is synthesized exclusively by fungi, mycobacteria and cyanobacteria (Pfeiffer, Bauer et al. 2011; Cheah and Halliwell 2012). Despite the inability of most animals and plants to synthesize ergothioneine, it is found in high concentrations in cells and tissues of plants and mammals (Cheah and Halliwell 2012). Interestingly, most cells are impermeable to ergothioneine, however, it can be transported into the cells via the organic cation transporter (OCTN1), which is encoded by the gene SLC22A4, in a $\mathrm{Na}^{+}$and $\mathrm{pH}$-dependent manner (Taubert, Grimberg et al. 2005; Nakamura, Sugiura et al. 2007; Cheah and Halliwell 2012). The same transporter is responsible for the initial intestinal uptake of ergothioneine (Halliwell, Cheah et al. 2018). OCTN1 shows high selectivity for ergothioneine and is expressed in different cell types and tissues, including brain neurons (Kato, Kubo et al. 2010; Nakamichi and Kato 2017; Tang, Cheah et al. 2018; Tschirka, Kreisor et al. 2018). High levels of ergothioneine may help maintain a higher GSH/GSSG ratio (Song, Lin et al. 2014), suggesting higher availability of reduced GSH to exert its antioxidant activity. Genetic deletion of OCTN1 results in increased oxidative stress and increased cell proliferation (Nakamichi, Taguchi et al. 2012). Ergothioneine is usually present in its thione form, showing high stability with high antioxidant potential. 
Ergothioneine exerts multiple effects on the central nervous system. Food supplementation in mice with ergothioneine (1.2 mg ergothioneine/g of food) for two weeks resulted in decreased depression-like, as well as higher neuronal differentiation in vivo (Nakamichi, Nakayama et al. 2016). Positive effects of ergothioneine treatment have been mentioned on learning and memory tasks, as well. Oral treatment with 0.5 or $2 \mathrm{mg} / \mathrm{kg}$ in mice for 16 days, blocked the compromising effects of treatment with $\beta$-amyloid in mice, on the Morris water maze test (Yang, Lin et al. 2012). Similarly, oral supplementation with 0.5 $\mathrm{mg} / \mathrm{kg}$ of ergothioneine for 88 days in mice, reversed the D-galactose-induced impairments on active avoidance behavior, as well as prevented the decline in the GSH/GSSG ratio (Song, Lin et al. 2014). These data suggest that ergothioneine could be a compound with therapeutic value in the preservation of GSH, as well as in relation to brain disorders.

4.2 L-carnitine. L-carnitine and its acetylated form acetyl-L-carnitine (ALC), which can cross the blood-brain-barrier, can exert an important function as a free radical scavenger protecting tissues and cell cultures from oxidative damage. ALC induces elevated GSH levels and activation of PI3K, PKG and ERK1/2 pathways in cortical neurons upon 4-Hydroxy-2-nonenal-induced oxidative stress (Mohmmad Abdul and Butterfield 2007). Moreover, L-carnitine increased GSH and upregulated the expression of GPx in control conditions and upon $\mathrm{H}_{2} \mathrm{O}_{2}$ oxidative challenge in oocytes and embryos of sheep (Mishra, Reddy et al. 2016). Only 25\% of L-carnitine comes from endogenous biosynthesis through methionine and protein bound lysine, while the rest is absorbed via the diet (Walter 1996).

Several studies have highlighted the antioxidant effects of L-carnitine. L-carnitine treatment $(1.5 \mathrm{~g} / \mathrm{L}$, in drinking water for five weeks) in rats chronically consuming ethanol decreased ethanol-mediated oxidative stress and increased the levels of GSH and vitamin E in the liver and blood serum of rats (Augustyniak and Skrzydlewska 2009). Similarly, ALC counteracted the arsenic-induced oxidative stress in a concentration-dependent way $(100,200,300 \mathrm{mg} / \mathrm{kg}$ for 21 days $)$, modulating antioxidant defense capacity and improving mitochondrial function in the rat hippocampus (KeshavarzBahaghighat, Sepand et al. 2018).

Related to its protective role in psychiatric disorders, in zebrafish, ALC prevented acute stress-induced anxiety (Pancotto, Mocelin et al. 2018). In mice, ALC treatment (25-100 mg/kg, i.p.) reduced 
depression-like behavior, as well as the chronic unpredictable stress-induced depression-like behavior (Wang, Lu et al. 2015). In humans, ALC has been reported to modulate synaptic transmission of multiple neurotransmitters, like acetylcholine, GABA, dopamine and serotonin (reviewed in (Pettegrew, Levine et al. 2000)) and have beneficial actions in MDD (1-2 g for 20-60 days) (Tempesta, Casella et al. 1987; Bella, Biondi et al. 1990; Garzya, Corallo et al. 1990; Gecele, Francesetti et al. 1991). These previous studies suggest a potential action of L-carnitine and ALC as protectors against oxidative damage in depression and anxiety.

4.3. Puerarin. Puerarin is an isoflavone found in the root of Pueraria plants (Yeung, Leung et al. 2006) with antioxidant potential (Kim, Kim et al. 2012). It has been shown to increase protein expression of Nrf2 and to protect against $\beta$-amyloid-induced toxicity in neuronal cultures from rat hippocampus (at concentrations as low as $3 \mu \mathrm{M}$ ) (Zou, Hong et al. 2013). Moreover, puerarin treatment in PC12 cells resulted in higher Nrf2 nuclear translocation following lead exposure, at a concentration of $30 \mu \mathrm{M}$, while it simultaneously increased GSH levels (Li, Pan et al. 2014). In vivo, puerarin treatment (200 $\mathrm{mg} / \mathrm{kg}$ ip, before 3-NP treatment for five consecutive days) rescued the 3-NP-induced impairments on prepulse inhibition, locomotion and reduced neurotransmitter and GSH levels, in Wistar rats (Mahdy, Mohamed et al. 2014). In conclusion, even though puerarin has not been studied extensively in the context of neuroprotection and neuromodulation, results so far indicate that it may be a potentially interesting compound.

\section{Safety and tolerability of GSH precursors and Nrf2 activators}

One major aspect in using GSH precursors and Nrf2 activators as potential therapeutic approaches to treat anxiety and stress disorders is their safety and tolerability profile. As one of the main reasons for therapy discontinuation of antidepressant treatments is their severe side effects (van Geffen, van der Wal et al. 2007), the compounds discussed here may offer an attractive alternative or complementary option. Indeed, several GSH precursors have been tested in clinical trials for safety and tolerability. NAC has been used in a double-blind placebo-controlled crossover phase I clinical trial in healthycocaine-dependent humans, which showed that NAC at a dose of $2400 \mathrm{mg}$ over $12 \mathrm{~h}$ was effective to 
reduce cocaine cravings without observed side effects (LaRowe, Mardikian et al. 2006). A metaanalysis of oral long-term NAC in chronic bronchopulmonary disease, also showed that NAC was well tolerated with very limited adverse effects at doses of 400-1200 mg daily for 3 to 6 months (usually gastrointestinal) (Grandjean, Berthet et al. 2000). In the case of taurine, doses of $3 \mathrm{~g} /$ day are considered safe for prolonged treatment in humans (Sirdah, El-Agouza et al. 2002; Shao and Hathcock 2008). Similarly, oral Glutamine treatment of 3-4 g/day for 8 weeks in humans showed no toxicity or other adverse effects (Shao and Hathcock 2008).

Supplementation with whey proteins in older adults was well tolerated at a dose of $45 \mathrm{~g} /$ day for 18 months in older individuals, without any signs of renal or liver toxicity (Kotler, Kerstetter et al. 2015), and a similar dose was well tolerated in HIV patients for 2 weeks (Micke, Beeh et al. 2001). Similarly, supplementation with approximately $7 \mathrm{~g}$ of whey protein daily for 2 months in Crohn`s patients was also well tolerated (Benjamin, Makharia et al. 2012). Nevertheless, there have been some reports of liver toxicity in rats after treatment with $0.5 \mathrm{~g} / \mathrm{kg}$ for 21 days (Żebrowska-Gamdzyk, Maciejczyk et al. 2018), or following treatment with extremely high doses of whey proteins ( $252 \mathrm{~g} / \mathrm{kg}$ for 4 weeks) (Gürgen, Yücel et al. 2015).

Compounds that activate Nrf2 have also exhibited high tolerability and lack of safety issues at clinically relevant doses. A phase I clinical trial using broccoli sprout extracts, containing sulforaphane, for seven days ( $25 \mu \mathrm{mol}$ glucosinolate, or $100 \mu \mathrm{mol}$, or $25 \mu \mathrm{mol}$ isothiocynate thrice daily) indicated no adverse or toxic effects (Shapiro, Fahey et al. 2006). Similarly, a randomized double blind placebo-controlled clinical trial in patients with chronic obstructive pulmonary disease showed high tolerability to doses of sulforaphane as high as $26.6 \mathrm{mg}$ (the highest used in the trial) (Wise, Holbrook et al. 2016). DMF has also been evaluated positively in terms of safety and tolerability in clinical trials at doses up to 240 mg twice or thrice per day, or delayed-release formulations and length of treatment between 4 days and two years resulting to dropout rates due to side effect ranging from 4-20 \% (Phillips, Fox et al. 2013; Sheikh, Nestorov et al. 2013; Zhovtis Ryerson, Green et al. 2016). Similarly, data from several studies and meta-analyses have suggested that curcumin has a good safety and tolerability profile tested in different populations, doses and treatment regimens, including doses as high as $4 \mathrm{~g}$ /day for 48 weeks, or 8 gr/day for 12 weeks (Ringman, Frautschy et al. 2012; Brondino, Re et al. 2014; Sanmukhani, 
Satodia et al. 2014; James, Iwuji et al. 2015; Al-Karawi, Al Mamoori et al. 2016). Treatment of curcumin up to $12 \mathrm{~g}$ /day for 12 weeks have been tested in myeloma patients without major adverse effects (Vadhan-Raj, Weber et al. 2007). Finally, melatonin has high tolerability at doses as high as 6 mg per day for 24 months, while effective doses were as low as $1 \mathrm{mg} /$ day in improving sleep quality in autistic patients (Guénolé, Godbout et al. 2011; Goldman, Adkins et al. 2014; Gonçalves, Martini Ferreira et al. 2016). Notably, the tolerability and safety of melatonin treatment has been tested in children, with promising results, as well (Guénolé, Godbout et al. 2011; Gringras, Nir et al. 2017).

Finally, other antioxidants such as ergothioneine and l-carnitine have been shown to be safe and tolerable for human use. Treatment of up to $9 \mathrm{~g} / \mathrm{kg} / \mathrm{day}$ of ergothioneine in the diet for two weeks resulted in no apparent toxicity in the treated animals (Forster, Spézia et al. 2015), and no effects of ergothioneine were observed in mutagenicity assays (Schauss, Vértesi et al. 2010), while doses of 25 $\mathrm{mg} /$ day for 7 days showed a trend towards lower expression of peripheral biomarkers of oxidative damage (Cheah, Tang et al. 2017). Thus, ergothioneine is generally considered safe for human consumption (EFSA Panel on Dietetic Products, Allergies et al. 2016). L-carnitine has been shown to lack side effects in humans at doses up to $7 \mathrm{~g} / \mathrm{kg}$ per day for seven days (Cruciani, Dvorkin et al. 2006) and in similar doses even for up to 2 months (Curran, Morhart et al. 2019). Regarding puerarin, a recent meta-analysis has suggested that treatment with up to $500 \mathrm{mg}$ of puerarin per day for 2-3 weeks was not accompanied by severe side effects, while doses of $200 \mathrm{mg}$ have been shown potential in improving the neurological condition following traumatic brain injury (Zheng, Li et al. 2017).

\section{Conclusions and discussion}

GSH is the main antioxidant in the brain (Dringen 2000). Its action is essential to neutralize excessive ROS production and prevent oxidative damage under conditions of high energy demand in the brain. Stress-related and anxiety disorders have been associated with reduced levels of GSH, increased levels of oxidative damage and/or reduced levels of expression of enzymes involved in GSH synthesis or recycling (Krömer, Keßler et al. 2005; Brocardo, Boehme et al. 2012; Krolow, Arcego et al. 2014). We propose in this review that increased energy demand induced by stress causes ROS overproduction eventually leading to a decrease in GSH levels. In addition, it is worth mentioning that stress might also 
impact GSH levels independently of its role as a ROS scavenger. GSH has been recently shown to act as a glutamate precursor in situations of impaired transport of glutamine from astrocytes to neurons (Sedlak, Paul et al. 2019). Remarkably, chronic social defeat stress has been associated with an impaired glutamine-glutamate cycle in astrocytes (Rappeneau, Blaker et al. 2016). These pieces of evidence suggest that GSH depletion upon this type of stress might be caused by both the neutralization of ROS or/and an increased demand of glutamate precursors. Moreover, it still remains unclear whether the reduction in brain GSH levels is exclusively a consequence of the stress or causal in nature. GSH brain levels are most likely determined by a complex interaction between an individual's genotype and the exposure to different environments and stressors. Therefore, we hypothesize that subjects with low basal brain GSH levels may show an increased vulnerability to stress due to a reduced capacity to neutralize ROS production.

Regardless of whether the differences in GSH are the cause or the consequence of stressed-induced behavioral alterations, several lines of evidence demonstrate that therapeutic interventions aiming to restore GSH in the brain may be an attractive possibility for the treatment of such disorders. Data reviewed here show that both precursors of the biosynthesis of GSH (e.g. NAC, taurine and whey proteins) and compounds that promote the expression of GSH-related enzymes (via activation of the Nrf2 pathway) can increase GSH levels in the brain and/or prevent the behavioral alterations induced by stress. An additional advantage of such an approach would be the high tolerability of these compounds and the high effective ranges without much adverse effects or toxicity, as discussed in this review. However, it is important to note that most studies have evaluated separately the capacity of these compounds to increase GSH in the brain or to modulate behavior. Therefore, future studies should systematically evaluate the impact of GSH boosters on GSH brain levels, in parallel with tests for behavioral performance under stress/after stress exposure.

The major determinants of GSH biosynthesis are the availability of cysteine and the activity of the ratelimiting enzyme GCL. GSH homeostasis is therefore dependent on the proper coordination between both determinants. Moreover, GSH may inhibit GCL and other enzymes, forming an inhibitory feedback loop controlling its own synthesis (Richman and Meister 1975a; Ishii and Warabi 2019). Theoretically, treatment only with GSH precursors might result in a saturation of the GSH biosynthetic 
pathways and thus inability to increase GSH levels beyond certain levels. Conversely, transcription of GCL (and other enzymes such as GST, GPx and GSR) via Nrf2 activation alone might be insufficient if the presence of precursors is still suboptimal. It is tempting to speculate, therefore, that using a combination of precursors of GSH synthesis and Nrf2 activators may have a stronger therapeutic potential.

It is noteworthy that several of the compounds discussed here, in addition to their effects on GSH levels, exert other effects. For example, NAC can elevate glutamate and dopamine release in the brain and exert anti-inflammatory effects (reviewed in (Dean, Giorlando et al. 2011; Berk, Malhi et al. 2013)). Similarly, whey protein supplementation can also increase dopamine release (Song, Tavitian et al. 2017). Sulforaphane can regulate mitochondrial function (Dinkova-Kostova and Abramov 2015). Therefore, it is important to bear in mind that the beneficial effects of these compounds on psychiatric disorders may be exerted at multiple levels (e.g. antioxidant potential, normalizing function on neurotransmitter release, regulating of mitochondrial function and anti-inflammatory effects).

In addition, when GSH-boosting compounds are systemically administered they may also exhibit peripheral effects on metabolism (Novelli, Santos et al. 2009; Falach-Malik, Rozenfeld et al. 2016) and doses need to be optimized, in order to achieve the maximum therapeutic effect combating oxidative damage in intended target organs (i.e. brain), but ensuring that in other organs ROS-dependent physiological processes are not negatively impacted (i.e. regulation of gene expression, cell proliferation, differentiation and viability via insulin, mitogen-activated protein kinase (MAPK) and cJun N-terminal kinase (JNK) signaling pathways (Goldstein, Mahadev et al. 2005; Bashan, Kovsan et al. 2009; Falach-Malik, Rozenfeld et al. 2016). On the other hand, it is worth mentioning that the impact of stress on oxidative damage and GSH levels is not restricted to the brain and the development of psychiatric diseases. Chronic stress has been described as a risk factor for cardiovascular diseases (Lagraauw, Kuiper et al. 2015), liver diseases (Russ, Kivimaki et al. 2015; Kang, Zhao et al. 2020) and obesity (Stefanaki, Pervanidou et al. 2018). In addition, redox imbalance upon stress exposure has been described in organs such as the liver (Zaidi, Al-Qirim et al. 2005; Ohta, Chiba et al. 2007; Cakir, Kasimay et al. 2010; Kaida, Ohta et al. 2010; Kour and Bani 2011; Kalaz, Evran et al. 2012; Demirdas, Naziroglu et al. 2016; Kim, Oh et al. 2016; Samarghandian, Farkhondeh et al. 2016; Samarghandian, 
Azimi-Nezhad et al. 2017b; Yi and Kim 2017; Lee, Jo et al. 2019), the gastrointestinal tract (Cakir, Kasimay et al. 2010; Banji, Banji et al. 2014), the kidneys (Demirdas, Naziroglu et al. 2016; Samarghandian, Farkhondeh et al. 2016; Samarghandian, Azimi-Nezhad et al. 2017b; Chen, Feng et al. 2018), the pancreas (Lopez-Lopez, Jaime et al. 2016) and the muscles (Hasan, Bilal et al. 2011; Hussien, El-Wakeel et al. 2019). It has been suggested that the stress-induced redox imbalance in peripheral organs is mediated by glucocorticoids (Zafir and Banu 2009b) as well as catecholamines and adrenoceptors (Zhu, Gu et al. 2014). Remarkably, some of the aforementioned studies demonstrated that treatment with compounds with antioxidant potential (Kaida, Ohta et al. 2010; Chen, Feng et al. 2018; Hussien, El-Wakeel et al. 2019) were able to revert both markers of oxidative damage and markers of organ failure in liver (e.g. altered values of serum alanine aminotransferase and aspartate aminotransferase or apoptosis in the liver) (Ohta, Chiba et al. 2007; Kaida, Ohta et al. 2010), kidney (e.g. increased serum urea nitrogen and creatinine, histopathological lesions in the renal tissue) (Chen, Feng et al. 2018) and heart (significant decrease in the left ventricular end-diastolic and systolic diameters and decrease in ejection fraction) (Hussien, El-Wakeel et al. 2019), providing a proof of principle that oxidative damage might be underlying the stress-induced pathophysiology in these organs. Finally, given the high comorbidity of stress-related psychopathology with metabolic or cardiovascular diseases (Nousen, Franco et al. 2013), the effects on periphery of compounds that increase GSH may not necessarily constitute a concern, but rather an additional level of therapeutic potential.

An important consideration must also be made for the potential effects of sex on GSH precursors and/or Nrf2 activators. Indeed, there is evidence that sexually mature female rodents exhibit increased antioxidant activity (Sobočanec, Balog et al. 2003) and GSH metabolism (Liu, Harrell et al. 2005; Dukhande, Isaac et al. 2009) in the brain. Such enhanced activity has been attributed to female reproductive hormones, as treatment with gonadal steroids in ovariectomized female rodents enhanced GSH levels following ischemic insult (Ozacmak and Sayan 2009) and sex steroid hormones are known to modulate the antioxidant enzyme activities (Pajović, Saicić et al. 2003). Thus, the mature female brain may be better protected from oxidative stress than males, which can have important implications for therapies focused on GSH enhancement. If females have a higher antioxidant capacity, they may 
exhibit less dramatic alterations in GSH following exposure to stress. In fact, several studies have found important sex differences in response to administration of GSH precursors such as NAC. For example, when male mice were exposed to a prenatal high fat diet, GSH levels in the hypothalamus were significantly lower than controls males, while female littermates only exhibited decreased GSH levels in the periphery (Berry, Bellisario et al. 2018). Interestingly, concomitant exposure to prenatal NAC treatment restored GSH levels in both the periphery and hypothalamus in males but exerted effects only in the periphery in female littermates (Berry, Bellisario et al. 2018). In another study, a low dose NAC treatment following severe hypoxia-ischemia effectively preserved infarct volume in neonatal females but not neonatal males (Nie, Lowe et al. 2016). When neonates were exposed to a higher dose, female infarct size worsened, while males exhibited no effects - either beneficial or detrimental (Nie, Wei et al. 2017). Interestingly, both delayed and long-term NAC treatments had beneficial effects for both sexes (Nie, Lowe et al. 2016). Evidence of sex differences in the effectiveness of Nrf2 activators, though scarce, also suggests sex-specificity in the sensitivity of cells to treatment. In a model of experimental autoimmune encephalomyelitis (EAE), adult male rats treated with dimethyl fumarate exhibited more prominent EAE attenuation that was associated with a larger increase in $\mathrm{Nrf} 2$ expression compared to female counterparts (Stojić-Vukanić, Kotur-Stevuljević et al. 2018). Taken together, these studies highlight the importance of taking sex differences into account when designing treatment and dosing regimens.

Finally, several methods have been developed to measure markers of redox status in accessible biological samples such as blood. These markers include isoprostanes (in plasma), protein carbonyls (in plasma and serum), 8-OHdG and single- and double-stranded DNA damage (in plasma, lymphocytes and serum) or fluorescent heme degradation products (whole blood) (Jacob, Noren Hooten et al. 2013). Likewise, the concentrations of GSH and GSSG in blood have been used as a proxy of the redox state of the organism. However, no agreement has yet been reached regarding the most appropriate analytical method, which might explain the considerable variability of GSH and GSSG concentrations reported between laboratories (Giustarini, Tsikas et al. 2016b). Another source of analytical inaccuracy is the artefactual oxidation of GSH to GSSG, which occurs during sample handling and consequently leads to an overestimation of GSSG concentrations (Rossi, Milzani et al. 2002; Giustarini, Tsikas et al. 
2016a). In order to prevent this artefactual oxidation, it is highly recommended (in tissue samples, whole blood samples and isolated red blood cells) to derivatize GSH with the alkylating agent $N$ ethylmaleimide (NEM) to form GS-NEM (Giustarini, Dalle-Donne et al. 2013). Afterwards GSH (or GS-NEM conjugates) and GSSG concentrations are measured either by HPLC or spectrophotometry with the GSH recycling method (Tietze 1969; Giustarini, Dalle-Donne et al. 2013). In white cells or platelets, this protocol is not suitable since GS-NEM conjugates translocate extracellularly and are lost during the procedure (Giustarini, Dalle-Donne et al. 2013). Other HPLC-based methods have been developed to measure GSH in small whole blood samples collected from dried blood spot (DBS) (Kandar, Stramova et al. 2015) or fingersticks (Giustarini, Fanti et al. 2014). In plasma, GSH concentration are lower (2-20 $\mu \mathrm{M}$ range, 1,000 times lower than whole blood) and there is a substantial amount of $-\mathrm{SH}$ present as free cysteine. For that reason, accurate measurements rely on sensitive techniques (i.e. HPLC separation and fluorimeter detection (Tipple and Rogers 2012)) and proper sampling pre-processing procedures (i.e. acidification of the samples, freezing and storage) (Claeson, Gouveia-Figueira et al. 2019). The development of methods for fast detection ( $<2 \mathrm{~min})$ of GSH and GSSG in plasma (Ngamchuea, Batchelor-McAuley et al. 2017) will help to overcome the negative impact of GSH autoxidation during sample handling. The relevant question is, however, to which extent measures of GSH (or other markers of oxidative damage) in blood can be used to monitor the progression of a certain mental disorder or the impact of a pharmacological intervention in the brain. Studies that correlate the levels of GSH in blood with those in brain tissue of the same individual (for instance using nuclear magnetic resonance ( ${ }^{1} \mathrm{H}-\mathrm{NMR}$ spectroscopy) are certainly necessary to determine whether GSH blood levels are a good surrogate marker for the levels of GSH in the brain. In conclusion, restoration of GSH levels and redox imbalance in the brain may be an attractive therapeutic possibility for anxiety and stress-related disorders. The high tolerability of compounds that can increase GSH levels, combined with their effects on neurotransmitter synthesis and release levels, may further accentuate their potential. 


\section{Box 1. Glutathione biochemistry.}

GSH is the main cellular antioxidant found in all mammalian tissues at $\sim 1-10 \mathrm{mM}$ concentrations. This tripeptide, $\gamma$-L-glutamyl-L-cysteinylglycine, can exist in a reduced state (GSH) or in an oxidized state (GSSG). Its antioxidant capacity is mediated by the thiol group present in the cysteine, which becomes oxidized when GSH reduces a target molecule. GSH participates in the neutralization of $\mathrm{H}_{2} \mathrm{O}_{2}$ in the cytosol in collaboration with the glutathione peroxidase (GPx) which takes hydrogens from two GSH molecules, converting one molecule of $\mathrm{H}_{2} \mathrm{O}_{2}$ into two of $\mathrm{H}_{2} \mathrm{O}$ and one of GSSG. Glutathione reductase (GSR) reduces GSSG back to GSH using NADPH as an electron donor. GSH is also a cofactor for other antioxidant enzymes including glutaredoxins (GLRX) and peroxiredoxines (PRX). Additionally, GSH can form disulfide bonds with thiol groups, a post-translational modification called S-glutathionylation, which protects cysteine thiols from further oxidation and can also regulate protein activity (Dringen and Hirrlinger 2003; Deponte 2013). Finally, GSH can also react non-enzymatically as a scavenger of ROS. Other functions have been ascribed to GSH, including the detoxification of xenobiotics and endogenous compounds, redox-signaling, iron-sulfur cluster biogenesis and protein folding (Bachhawat and Kaur 2017; Calabrese, Morgan et al. 2017). The capacity to synthesize GSH is virtually present in all mammalian cells and involves two ATP-dependent cytosolic reactions. In the first reaction, glutamate cysteine ligase (GCL) catalyzes the formation of $\gamma$-glutamylcysteine from glutamate and cysteine (Orlowski and Meister 1971). In the second reaction, glutathione synthase (GSS) forms the tripeptide by linking glycine to $\gamma$-glutamylcysteine (Snoke 1955). In the synthesis of GSH, GCL is the ratelimiting enzyme (Richman and Meister 1975b; Dalton, Chen et al. 2004) and cysteine is the rate-limiting substrate (Richman and Meister 1975b; Bannai and Tateishi 1986). The main enzyme that initiates the process of GSH degradation is named glutamyl transpeptidase (GGT). In mammals, this enzyme is localized in the plasma membrane, facing outwards and acting on the extracellular pool of GSH released by the cells. The degradation of GSH by GGTs generates $\gamma$-glutamyl-aminoacids and cysteine-glycine dipeptides, which are subjected to the action of membrane-bound peptidase to yield cysteine and glycine. Therefore, the major function of GGT is to recover GSH precursors from extracellular pools which can be lately taken up by cells and used for the new synthesis of GSH (Bachhawat and Kaur 2017). In the brain, GSH homeostasis has an additional level of complexity in that the expression of 
GSH and GSH-related enzymes are not evenly distributed across all cell types, requiring the coordination between neurons and astrocytes to neutralize oxidative insults. While both neurons and astrocytes are capable of GSH synthesis, astrocytes have a higher capacity for the production, storage and releasing of GSH into the extracellular medium in an oxidative stress-dependent manner (Belanger, Allaman et al. 2011). Additionally, astrocytes express higher levels of Nrf2, the main antioxidant response system regulator, compared to neurons (Shih et al., 2003; Vargas and Johnson, 2009)(Kraft, Johnson et al. 2004; Bell, Al-Mubarak et al. 2015). Synthesis of GSH in neurons is therefore highly reliant on the uptake of precursors obtained from the degradation of GSH synthetized by astrocytes (Dringen R. 2000) (see also Figure 1).

\section{Acknowledgements}

This work was supported by grants from the Swiss National Science Foundation [(grants 31003A152614 and 51NF40-158776 (NCCR Synapsy)] to the EFPL team.

\section{Authors' contributions}

IZ, FH, ER-F, CS and LM drafted the original manuscript, designed tables and figures. IZ, FH, ER-F, LT, SS, EG, NP, PS, CS and LM critically reviewed the drafts. All authors approved the final version.

\section{Declaration of competing interest}

Laura Trovo, Sarah Sonnay, Eveline Geiser, Nicolas Preitner, and Pascal Steiner are employees of Société des Produits Nestlé S.A. 


\section{References}

Abd El-Fattah, A. A., A. T. Fahim, et al. (2018). Resveratrol and dimethyl fumarate ameliorate depression-like behaviour in a rat model of chronic unpredictable mild stress. Brain Research 1701: 227-236.

Abd El Mohsen, M. M., M. M. Iravani, et al. (2005). Age-associated changes in protein oxidation and proteasome activities in rat brain: Modulation by antioxidants. Biochemical and Biophysical Research Communications 336(2): 386-391.

Ahmad, S., C. W. White, et al. (2001). Glutamine protects mitochondrial structure and function in oxygen toxicity. American Journal of Physiology-Lung Cellular and Molecular Physiology 280(4): L779-L791.

Al-Karawi, D., D. A. Al Mamoori, et al. (2016). The Role of Curcumin Administration in Patients with Major Depressive Disorder: Mini Meta-Analysis of Clinical Trials. Phytotherapy Research 30(2): 175-183.

Albrecht, J., M. Sidoryk-Węgrzynowicz, et al. (2010). Roles of glutamine in neurotransmission. Neuron Glia Biology 6(4): 263-276.

Albrecht, P., I. Bouchachia, et al. (2012). Effects of dimethyl fumarate on neuroprotection and immunomodulation. Journal of Neuroinflammation 9(1): 163.

Aleman, A., T. M. Lincoln, et al. (2017). Treatment of negative symptoms: Where do we stand, and where do we go? Schizophrenia Research 186: 55-62.

Allen, J. and R. D. Bradley (2011). Effects of Oral Glutathione Supplementation on Systemic Oxidative Stress Biomarkers in Human Volunteers. The Journal of Alternative and Complementary Medicine 17(9): 827-833.

Angelova, P. R. and A. Y. Abramov (2018). Role of mitochondrial ROS in the brain: from physiology to neurodegeneration. FEBS Letters 592(5): 692-702.

Arakawa, M. and Y. Ito (2007). N-acetylcysteine and neurodegenerative diseases: Basic and clinical pharmacology. The Cerebellum 6(4): 308-314.

Atmaca, M., M. Kuloglu, et al. (2008). Antioxidant enzyme and malondialdehyde levels in patients with social phobia. Psychiatry Research 159(1): 95-100.

Atmaca, M., E. Tezcan, et al. (2004). Antioxidant enzyme and malondialdehyde valuesin social phobia before and after citalopram treatment. Eur Arch Psychiatry Clin Neurosci 254(4): 231-235.

Aubry, A. V., H. Khandaker, et al. (2019). A diet enriched with curcumin promotes resilience to chronic social defeat stress. Neuropsychopharmacology 44(4): 733-742.

Augustyniak, A. and E. Skrzydlewska (2009). 1-Carnitine in the lipid and protein protection against ethanol-induced oxidative stress. Alcohol 43(3): 217-223.

Aydın, A. F., J. Çoban, et al. (2016). Carnosine and taurine treatments diminished brain oxidative stress and apoptosis in D-galactose aging model. Metabolic Brain Disease 31(2): 337-345.

Bachhawat, A. K. and A. Kaur (2017). Glutathione Degradation. Antioxid Redox Signal 27(15): 1200-1216.

Baird, L., S. Swift, et al. (2014). Monitoring Keap1-Nrf2 interactions in single live cells. Biotechnology Advances 32(6): 1133-1144.

Bajpai, A., A. K. Verma, et al. (2014). Oxidative stress and major depression. J Clin Diagn Res 8(12): CC04-07.

Ballatori, N., M. Krance Suzanne, et al. (2009). Glutathione dysregulation and the etiology and progression of human diseases. Biological Chemistry. 390: 191.

Balogun, E., M. Hoque, et al. (2003). Curcumin activates the haem oxygenase-1 gene via regulation of Nrf2 and the antioxidant-responsive element. Biochemical Journal 371(3): 887-895. 
Banji, D., O. J. Banji, et al. (2014). Zingerone regulates intestinal transit, attenuates behavioral and oxidative perturbations in irritable bowel disorder in rats. Phytomedicine 21(4): 423-429.

Bannai, S. and N. Tateishi (1986). Role of membrane transport in metabolism and function of glutathione in mammals. J Membr Biol 89(1): 1-8.

Barlow-Walden, L. R., R. J. Reiter, et al. (1995). Melatonin stimulates brain glutathione peroxidase activity. Neurochemistry International 26(5): 497-502.

Bashan, N., J. Kovsan, et al. (2009). Positive and Negative Regulation of Insulin Signaling by Reactive Oxygen and Nitrogen Species. Physiological Reviews 89(1): 27-71.

Baydaş, G., E. Erçel, et al. (2001). Effect of melatonin on oxidative status of rat brain, liver and kidney tissues under constant light exposure. Cell Biochemistry and Function 19(1): 37-41.

Baydas, G. and M. Tuzcu (2005). Protective effects of melatonin against ethanol-induced reactive gliosis in hippocampus and cortex of young and aged rats. Experimental Neurology 194(1): 175-181.

Belanger, M., I. Allaman, et al. (2011). Brain energy metabolism: focus on astrocyte-neuron metabolic cooperation. Cell Metab 14(6): 724-738.

Bella, R., R. Biondi, et al. (1990). Effect of acetyl-L-carnitine on geriatric patients suffering from dysthymic disorders. International journal of clinical pharmacology research 10(6): 355-360.

Benes, F. M., D. Matzilevich, et al. (2005). The expression of proapoptosis genes is increased in bipolar disorder, but not in schizophrenia. Molecular Psychiatry 11: 241.

Benjamin, J., G. Makharia, et al. (2012). Glutamine and Whey Protein Improve Intestinal Permeability and Morphology in Patients with Crohn's Disease: A Randomized Controlled Trial. Digestive Diseases and Sciences 57(4): 1000-1012.

Bergström, P., H. C. Andersson, et al. (2011). Repeated transient sulforaphane stimulation in astrocytes leads to prolonged Nrf2-mediated gene expression and protection from superoxide-induced damage. Neuropharmacology 60(2): 343-353.

Berk, M., D. L. Copolov, et al. (2008). N-Acetyl Cysteine for Depressive Symptoms in Bipolar Disorder-A Double-Blind Randomized Placebo-Controlled Trial. Biological Psychiatry 64(6): 468-475.

Berk, M., O. M. Dean, et al. (2012). Maintenance N-acetyl cysteine treatment for bipolar disorder: A double-blind randomized placebo controlled trial. BMC Med 10(1): 91.

Berk, M., O. M. Dean, et al. (2014). The efficacy of adjunctive N-acetylcysteine in major depressive disorder: a double-blind, randomized, placebo-controlled trial. The Journal of clinical psychiatry 75(6): 628-636.

Berk, M., G. S. Malhi, et al. (2013). The promise of N-acetylcysteine in neuropsychiatry. Trends in Pharmacological Sciences 34(3): 167-177.

Berry, A., V. Bellisario, et al. (2018). Administration of the Antioxidant N-Acetyl-Cysteine in Pregnant Mice Has Long-Term Positive Effects on Metabolic and Behavioral Endpoints of Male and Female Offspring Prenatally Exposed to a High-Fat Diet. Front Behav Neurosci 12: 48-48.

Berry, A., M. Marconi, et al. (2020). Trehalose administration in C57BL/6N old mice affects healthspan improving motor learning and brain anti-oxidant defences in a sexdependent fashion: a pilot study. Exp Gerontol 129: 110755-110755.

Beytut, E., S. Yilmaz, et al. (2018). The possible protective effects of vitamin E and selenium administration in oxidative stress caused by high doses of glucocorticoid administration in the brain of rats. Journal of Trace Elements in Medicine and Biology 45: 131-135. 
Black, C. N., M. Bot, et al. (2015). Is depression associated with increased oxidative stress? A systematic review and meta-analysis. Psychoneuroendocrinology 51: 164-175.

Bonnefont-Rousselot, D. and F. Collin (2010). Melatonin: Action as antioxidant and potential applications in human disease and aging. Toxicology 278(1): 55-67.

Bouvier, E., F. Brouillard, et al. (2016). Nrf2-dependent persistent oxidative stress results in stress-induced vulnerability to depression. Mol Psychiatry.

Bowers, M. S., A. Jackson, et al. (2016). N-acetylcysteine decreased nicotine reward-like properties and withdrawal in mice. Psychopharmacology 233(6): 995-1003.

Brocardo, P. S., F. Boehme, et al. (2012). Anxiety- and depression-like behaviors are accompanied by an increase in oxidative stress in a rat model of fetal alcohol spectrum disorders: Protective effects of voluntary physical exercise. Neuropharmacology 62(4): 1607-1618.

Brondino, N., S. Re, et al. (2014). Curcumin as a Therapeutic Agent in Dementia: A Mini Systematic Review of Human Studies. The Scientific World Journal 2014: 6.

Bryan, H. K., A. Olayanju, et al. (2013). The Nrf2 cell defence pathway: Keap1-dependent and -independent mechanisms of regulation. Biochemical Pharmacology 85(6): 705717.

Bryan, R. M., Jr. (1990). Cerebral blood flow and energy metabolism during stress. Am J Physiol 259(2 Pt 2): H269-280.

Cakir, B., O. Kasimay, et al. (2010). Stress-induced multiple organ damage in rats is ameliorated by the antioxidant and anxiolytic effects of regular exercise. Cell Biochem Funct 28(6): 469-479.

Calabrese, G., B. Morgan, et al. (2017). Mitochondrial Glutathione: Regulation and Functions. Antioxid Redox Signal 27(15): 1162-1177.

Calvo, D. J. and A. N. B. González (2016). Dynamic Regulation of the GABA $<\operatorname{sub}>A</ s u b>$ Receptor Function by Redox Mechanisms. Molecular Pharmacology 90(3): 326-333.

Canning, P., F. J. Sorrell, et al. (2015). Structural basis of Keap1 interactions with Nrf2. Free Radical Biology and Medicine 88: 101-107.

Che, Y., J. F. Wang, et al. (2010). Oxidative damage to RNA but not DNA in the hippocampus of patients with major mental illness. J Psychiatry Neurosci 35(5): 296302.

Cheah, I. K. and B. Halliwell (2012). Ergothioneine; antioxidant potential, physiological function and role in disease. Biochimica et Biophysica Acta (BBA) - Molecular Basis of Disease 1822(5): 784-793.

Cheah, I. K., R. M. Y. Tang, et al. (2017). Administration of Pure Ergothioneine to Healthy Human Subjects: Uptake, Metabolism, and Effects on Biomarkers of Oxidative Damage and Inflammation. Antioxidants \& Redox Signaling 26(5): 193-206.

Chen, A. and J. Xu (2005). Activation of PPAR $\gamma$ by curcumin inhibits Moser cell growth and mediates suppression of gene expression of cyclin D1 and EGFR. American Journal of Physiology-Gastrointestinal and Liver Physiology 288(3): G447-G456.

Chen, S. W., W. X. Kong, et al. (2004). Possible anxiolytic effects of taurine in the mouse elevated plus-maze. Life Sciences 75(12): 1503-1511.

Chen, X.-L. and C. Kunsch (2004). Induction of Cytoprotective Genes Through Nrf2 / Antioxidant Response Element Pathway: A New Therapeutic Approach for the Treatment of Inflammatory Diseases. Current Pharmaceutical Design 10(8): 879-891.

Chen, Y., X. Feng, et al. (2018). Dexmedetomidine Ameliorates Acute Stress-Induced Kidney Injury by Attenuating Oxidative Stress and Apoptosis through Inhibition of the ROS/JNK Signaling Pathway. Oxid Med Cell Longev 2018: 4035310. 
Choi, I.-Y., P. Lee, et al. (2014). Dairy intake is associated with brain glutathione concentration in older adults. The American Journal of Clinical Nutrition 101(2): 287293.

Claeson, A. S., S. Gouveia-Figueira, et al. (2019). A standardized protocol for comparable analysis of GSH/GSSG by UHPLC-ESI-MSMS for human plasma. J Chromatogr B Analyt Technol Biomed Life Sci 1104: 67-72.

Clark, D. D. and L. Sokoloff (1999). Basic Neurochemistry: Molecular, Cellular and Medical Aspects. Lippincott, Philadelphia.

Cobley, J. N., M. L. Fiorello, et al. (2018). 13 reasons why the brain is susceptible to oxidative stress. Redox Biology 15: 490-503.

Coles, L. D., P. J. Tuite, et al. (2018). Repeated-Dose Oral N-Acetylcysteine in Parkinson's Disease: Pharmacokinetics and Effect on Brain Glutathione and Oxidative Stress. The Journal of Clinical Pharmacology 58(2): 158-167.

Conus, P., L. J. Seidman, et al. (2017). N-acetylcysteine in a Double-Blind Randomized Placebo-Controlled Trial: Toward Biomarker-Guided Treatment in Early Psychosis. Schizophr Bull 44(2): 317-327.

Corcoba, A., R. Gruetter, et al. (2017). Social isolation stress and chronic glutathione deficiency have a common effect on the glutamine-to-glutamate ratio and myoinositol concentration in the mouse frontal cortex. Journal of Neurochemistry 142(5): 767-775.

Corrochano, A. R., V. Buckin, et al. (2018). Invited review: Whey proteins as antioxidants and promoters of cellular antioxidant pathways. Journal of Dairy Science 101(6): 4747-4761.

Cruciani, R. A., E. Dvorkin, et al. (2006). Safety, Tolerability and Symptom Outcomes Associated with 1-Carnitine Supplementation in Patients with Cancer, Fatigue, and Carnitine Deficiency: A Phase I/II Study. Journal of Pain and Symptom Management 32(6): 551-559.

Cui, Q., L. Xin, et al. (2015). Curcumin ameliorates dopaminergic neuronal oxidative damage via activation of the Akt/Nrf2 pathway. Molecular Medicine Reports 13(2): 8.

Cullinan, S. B., D. Zhang, et al. (2003). Nrf2 Is a Direct PERK Substrate and Effector of PERK-Dependent Cell Survival. Molecular and Cellular Biology 23(20): 7198-7209.

Curran, M. W. T., M. J. Morhart, et al. (2019). Acetyl-1-Carnitine to Enhance Nerve Regeneration in Carpal Tunnel Syndrome: A Double-Blind, Randomized, Controlled Trial. Plastic and Reconstructive Surgery 143(1): 111e-120e.

Da Silva Morrone, M., C. E. Schnorr, et al. (2016). Oral administration of curcumin relieves behavioral alterations and oxidative stress in the frontal cortex, hippocampus, and striatum of ovariectomized Wistar rats. The Journal of Nutritional Biochemistry 32: 181-188.

Dalton, T. P., Y. Chen, et al. (2004). Genetically altered mice to evaluate glutathione homeostasis in health and disease. Free Radic Biol Med 37(10): 1511-1526.

Daverey, A. and S. K. Agrawal (2016). Curcumin alleviates oxidative stress and mitochondrial dysfunction in astrocytes. Neuroscience 333: 92-103.

Daverey, A. and S. K. Agrawal (2018). Pre and post treatment with curcumin and resveratrol protects astrocytes after oxidative stress. Brain Research 1692: 45-55.

de Kloet, E. R., S. F. de Kloet, et al. (2019). Top-down and bottom-up control of stresscoping. Journal of Neuroendocrinology 31(3): e12675.

de Kloet, E. R., M. Joels, et al. (2005). Stress and the brain: from adaptation to disease. Nat Rev Neurosci 6(6): 463-475.

de Lima, D. S. C., E. d. S. Francisco, et al. (2017). Neonatal l-glutamine modulates anxietylike behavior, cortical spreading depression, and microglial immunoreactivity: 
analysis in developing rats suckled on normal size- and large size litters. Amino Acids 49(2): 337-346.

Dean, O., F. Giorlando, et al. (2011). N-acetylcysteine in psychiatry: current therapeutic evidence and potential mechanisms of action. Journal of psychiatry \& neuroscience : JPN 36(2): 78-86.

Demirdas, A., M. Naziroglu, et al. (2016). Agomelatine reduces brain, kidney and liver oxidative stress but increases plasma cytokine production in the rats with chronic mild stress-induced depression. Metab Brain Dis 31(6): 1445-1453.

Deponte, M. (2013). Glutathione catalysis and the reaction mechanisms of glutathionedependent enzymes. Biochim Biophys Acta 1830(5): 3217-3266.

Di Pasqua, A. J., F.-L. Chung, et al. (2011). Proteins as binding targets of isothiocyanates in cancer prevention. Carcinogenesis 32(10): 1405-1413.

Dimopoulos, N., C. Piperi, et al. (2008). Increased plasma levels of 8-iso-PGF2alpha and IL6 in an elderly population with depression. Psychiatry Res 161(1): 59-66.

Ding, K., H. Wang, et al. (2014). Melatonin stimulates antioxidant enzymes and reduces oxidative stress in experimental traumatic brain injury: the Nrf2-ARE signaling pathway as a potential mechanism. Free Radical Biology and Medicine 73: 1-11.

Ding, X.-F., Y.-H. Li, et al. (2017). Involvement of the glutamate/glutamine cycle and glutamate transporter GLT-1 in antidepressant-like effects of Xiao Yao san on chronically stressed mice. BMC complementary and alternative medicine 17(1): 326.

Dinkova-Kostova, A. T. and A. Y. Abramov (2015). The emerging role of Nrf2 in mitochondrial function. Free Radical Biology and Medicine 88: 179-188.

Dinkova-Kostova, A. T., W. D. Holtzclaw, et al. (2002). Direct evidence that sulfhydryl groups of Keap1 are the sensors regulating induction of phase 2 enzymes that protect against carcinogens and oxidants. Proceedings of the National Academy of Sciences 99(18): 11908-11913.

Dinkova-Kostova, A. T., W. D. Holtzclaw, et al. (2005). The Role of Keap1 in Cellular Protective Responses. Chemical Research in Toxicology 18(12): 1779-1791.

Dinkova-Kostova, A. T., R. V. Kostov, et al. (2017). Keap1, the cysteine-based mammalian intracellular sensor for electrophiles and oxidants. Archives of Biochemistry and Biophysics 617: 84-93.

Djordjevic, J., A. Djordjevic, et al. (2010). Chronic Social Isolation Compromises the Activity of Both Glutathione Peroxidase and Catalase in Hippocampus of Male Wistar Rats. Cellular and Molecular Neurobiology 30(5): 693-700.

Dolu, N. (2007). Dose-related anxiogenic effect of glycine in the elevated plus maze and in electrodermal activity. Journal of basic and clinical physiology and pharmacology 18(2): 141-147.

Dong, W., B. Yang, et al. (2018). Curcumin plays neuroprotective roles against traumatic brain injury partly via Nrf2 signaling. Toxicology and Applied Pharmacology 346: 28-36.

Dringen, R. (2000). Metabolism and functions of glutathione in brain. Progress in Neurobiology 62(6): 649-671.

Dringen, R. and J. Hirrlinger (2003). Glutathione pathways in the brain. Biol Chem 384(4): 505-516.

Dringen, R., P. G. Pawlowski, et al. (2005). Peroxide detoxification by brain cells. Journal of Neuroscience Research 79(1-2): 157-165.

Dukhande, V. V., A. O. Isaac, et al. (2009). Reduced glutathione regenerating enzymes undergo developmental decline and sexual dimorphism in the rat cerebral cortex. Brain Research 1286: 19-24. 
EFSA Panel on Dietetic Products, N., Allergies, et al. (2016). Safety of synthetic 1ergothioneine (Ergoneine ${ }^{\circledR}$ ) as a novel food pursuant to Regulation (EC) No 258/97. EFSA Journal 14(11): e04629.

El Idrissi, A., C. H. Shen, et al. (2013). Neuroprotective role of taurine during aging. Amino Acids 45(4): 735-750.

Falach-Malik, A., H. Rozenfeld, et al. (2016). N-Acetyl-L-Cysteine inhibits the development of glucose intolerance and hepatic steatosis in diabetes-prone mice. American journal of translational research 8(9): 3744-3756.

Falkowski, M., M. Maciejczyk, et al. (2018). Whey Protein Concentrate WPC-80 Improves Antioxidant Defense Systems in the Salivary Glands of 14-Month Wistar Rats. Nutrients 10(6): 782.

Fan, C., Q. Song, et al. (2018). Curcumin Protects Against Chronic Stress-induced Dysregulation of Neuroplasticity and Depression-like Behaviors via Suppressing IL$1 \beta$ Pathway in Rats. Neuroscience 392: 92-106.

Fernandes, B. S., O. M. Dean, et al. (2016). N-Acetylcysteine in Depressive Symptoms and Functionality: A Systematic Review and Meta-Analysis. Journal of Clinical Psychiatry 77(4): 10.

Fernandez-Fernandez, S., V. Bobo-Jimenez, et al. (2018). Hippocampal neurons require a large pool of glutathione to sustain dendrite integrity and cognitive function. Redox Biology 19: 52-61.

Ferreira-Chamorro, P., A. Redondo, et al. (2018). Sulforaphane Inhibited the Nociceptive Responses, Anxiety- and Depressive-Like Behaviors Associated With Neuropathic Pain and Improved the Anti-allodynic Effects of Morphine in Mice. Frontiers in Pharmacology 9(1332).

Forlenza, M. J. and G. E. Miller (2006). Increased serum levels of 8-hydroxy-2'deoxyguanosine in clinical depression. Psychosom Med 68(1): 1-7.

Forster, R., F. Spézia, et al. (2015). Reproductive safety evaluation of L-Ergothioneine. Food and Chemical Toxicology 80: 85-91.

Fraunberger, E. A., G. Scola, et al. (2016). Redox Modulations, Antioxidants, and Neuropsychiatric Disorders. Oxidative Medicine and Cellular Longevity 2016: 14.

Freed, R. D., C. N. Hollenhorst, et al. (2017). A pilot study of cortical glutathione in youth with depression. Psychiatry Research: Neuroimaging 270: 54-60.

Friedman, J. (2011). Why Is the Nervous System Vulnerable to Oxidative Stress? Oxidative Stress and Free Radical Damage in Neurology. N. Gadoth and H. H. Göbel. Totowa, NJ, Humana Press: 19-27.

Garzya, G., D. Corallo, et al. (1990). Evaluation of the effects of L-acetylcarnitine on senile patients suffering from depression. Drugs under experimental and clinical research 16(2): 101-106.

Gecele, M., G. Francesetti, et al. (1991). Acetyl- $<\mathrm{i}>\mathrm{L}</ \mathrm{i}>$-Carnitine in Aged Subjects with Major Depression: Clinical Efficacy and Effects on the Circadian Rhythm of Cortisol. Dementia and Geriatric Cognitive Disorders 2(6): 333-337.

Giustarini, D., I. Dalle-Donne, et al. (2013). Analysis of GSH and GSSG after derivatization with N-ethylmaleimide. Nature protocols 8(9): 1660-1669.

Giustarini, D., P. Fanti, et al. (2014). Micro-method for the determination of glutathione in human blood. J Chromatogr B Analyt Technol Biomed Life Sci 964: 191-194.

Giustarini, D., D. Tsikas, et al. (2016a). Pitfalls in the analysis of the physiological antioxidant glutathione (GSH) and its disulfide (GSSG) in biological samples: An elephant in the room. J Chromatogr B Analyt Technol Biomed Life Sci 1019: 21-28.

Giustarini, D., D. Tsikas, et al. (2016b). Pitfalls in the analysis of the physiological antioxidant glutathione (GSH) and its disulfide (GSSG) in biological samples: An 
elephant in the room. Journal of chromatography. B, Analytical technologies in the biomedical and life sciences 1019: 21-28.

Godlewska, B. R., J. Near, et al. (2015). Neurochemistry of major depression: a study using magnetic resonance spectroscopy. Psychopharmacology 232(3): 501-507.

Goldman, S. E., K. W. Adkins, et al. (2014). Melatonin in Children with Autism Spectrum Disorders: Endogenous and Pharmacokinetic Profiles in Relation to Sleep. Journal of Autism and Developmental Disorders 44(10): 2525-2535.

Goldstein, B. J., K. Mahadev, et al. (2005). Redox Paradox. Insulin Action Is Facilitated by Insulin-Stimulated Reactive Oxygen Species With Multiple Potential Signaling Targets 54(2): 311-321.

Gonçalves, A. L., A. Martini Ferreira, et al. (2016). Randomised clinical trial comparing melatonin $3 \mathrm{mg}$, amitriptyline $25 \mathrm{mg}$ and placebo for migraine prevention. Journal of Neurology, Neurosurgery \&amp; Psychiatry 87(10): 1127-1132.

Gorrini, C., I. S. Harris, et al. (2013). Modulation of oxidative stress as an anticancer strategy. Nature Reviews Drug Discovery 12: 931.

Graf, S., S. Egert, et al. (2011). Effects of whey protein supplements on metabolism: evidence from human intervention studies. Current Opinion in Clinical Nutrition \& Metabolic Care 14(6): 569-580.

Grandjean, E. M., P. Berthet, et al. (2000). Efficacy of oral long-term N-acetylcysteine in chronic bronchopulmonary disease: A meta-analysis of published double-blind, placebo-controlled clinical trials. Clinical Therapeutics 22(2): 209-221.

Grant, J. E., B. L. Odlaug, et al. (2009). N-Acetylcysteine, a Glutamate Modulator, in the Treatment of Trichotillomania: A Double-blind, Placebo-Controlled Study. JAMA Psychiatry 66(7): 756-763.

Gringras, P., T. Nir, et al. (2017). Efficacy and Safety of Pediatric Prolonged-Release Melatonin for Insomnia in Children With Autism Spectrum Disorder. Journal of the American Academy of Child \& Adolescent Psychiatry 56(11): 948-957.e944.

Guénolé, F., R. Godbout, et al. (2011). Melatonin for disordered sleep in individuals with autism spectrum disorders: Systematic review and discussion. Sleep Medicine Reviews 15(6): 379-387.

Gürgen, S., A. Yücel, et al. (2015). Usage of whey protein may cause liver damage via inflammatory and apoptotic responses. Human \& Experimental Toxicology 34(7): 769-779.

Gustavsson, A., M. Svensson, et al. (2011). Cost of disorders of the brain in Europe 2010. European Neuropsychopharmacology 21(10): 718-779.

Hagen, T. M., G. T. Wierzbicka, et al. (1990). Bioavailability of dietary glutathione: effect on plasma concentration. American Journal of Physiology-Gastrointestinal and Liver Physiology 259(4): G524-G529.

Hall, C. N., M. C. Klein-Flügge, et al. (2012). Oxidative Phosphorylation, Not Glycolysis, Powers Presynaptic and Postsynaptic Mechanisms Underlying Brain Information Processing. The Journal of Neuroscience 32(26): 8940-8951.

Hall, J. C. (1998). Review: Glycine. Journal of Parenteral and Enteral Nutrition 22(6): 393398.

Halliwell, B. (2006). Oxidative stress and neurodegeneration: where are we now? Journal of Neurochemistry 97(6): 1634-1658.

Halliwell, B., I. K. Cheah, et al. (2018). Ergothioneine - a diet-derived antioxidant with therapeutic potential. FEBS Letters 592(20): 3357-3366.

Hariharakrishnan, J., T. Anand, et al. (2009). Activity and gene expression profile of certain antioxidant enzymes in different organs of rats after subacute cyanide exposure: Effect of alpha-ketoglutarate. Drug and Chemical Toxicology 32(3): 268-276. 
Harris, Julia J., R. Jolivet, et al. (2012). Synaptic Energy Use and Supply. Neuron 75(5): 762777.

Harvey, C. J., R. K. Thimmulappa, et al. (2009). Nrf2-regulated glutathione recycling independent of biosynthesis is critical for cell survival during oxidative stress. Free Radical Biology and Medicine 46(4): 443-453.

Hasan, S., N. Bilal, et al. (2011). Multivitamin-mineral and vitamins (E + C) supplementation modulate chronic unpredictable stress-induced oxidative damage in brain and heart of mice. Biol Trace Elem Res 142(3): 589-597.

Hasebe, K., L. Gray, et al. (2017). Adjunctive N-acetylcysteine in depression: exploration of interleukin-6, C-reactive protein and brain-derived neurotrophic factor. Acta Neuropsychiatrica 29(6): 337-346.

Hauser, R. A., K. E. Lyons, et al. (2009). Randomized, double-blind, pilot evaluation of intravenous glutathione in Parkinson's disease. Movement Disorders 24(7): 979-983.

Hayes, J. D., S. A. Chanas, et al. (2000). The Nrf2 transcription factor contributes both to the basal expression of glutathione S-transferases in mouse liver and to their induction by the chemopreventive synthetic antioxidants, butylated hydroxyanisole and ethoxyquin. Biochemical Society Transactions 28(2): 33-41.

He, Q., Y. Wang, et al. (2014). Trehalose Alleviates PC12 Neuronal Death Mediated by Lipopolysaccharide-Stimulated BV-2 Cells via Inhibiting Nuclear Transcription

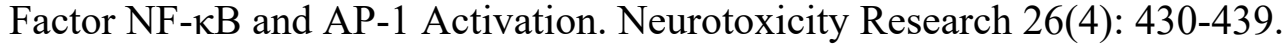

Herbet, M., A. Korga, et al. (2017a). Chronic Variable Stress Is Responsible for Lipid and DNA Oxidative Disorders and Activation of Oxidative Stress Response Genes in the Brain of Rats. Oxid Med Cell Longev 2017: 7313090.

Herbet, M., A. Korga, et al. (2017b). Chronic Variable Stress Is Responsible for Lipid and DNA Oxidative Disorders and Activation of Oxidative Stress Response Genes in the Brain of Rats. Oxidative Medicine and Cellular Longevity 2017: 7313090-7313090.

Heresco-Levy, U., D. C. Javitt, et al. (1996). Double-Blind, Placebo-Controlled, Crossover Trial of Glycine Adjuvant Therapy for Treatment-Resistant Schizophrenia. British Journal of Psychiatry 169(5): 610-617.

Herman, J. P. and J. G. Tasker (2016). Paraventricular Hypothalamic Mechanisms of Chronic Stress Adaptation. Frontiers in Endocrinology 7(137).

Herrero-Mendez, A., A. Almeida, et al. (2009). The bioenergetic and antioxidant status of neurons is controlled by continuous degradation of a key glycolytic enzyme by APC/C-Cdh1. Nat Cell Biol 11(6): 747-752.

Herrmann, A. P., R. Benvenutti, et al. (2014). N-acetylcysteine prevents increased amphetamine sensitivity in social isolation-reared mice. Schizophrenia Research 155(1): 109-111.

Hirschtritt, M. E., M. H. Bloch, et al. (2017). Obsessive-Compulsive Disorder: Advances in Diagnosis and TreatmentDiagnosis and Treatment of Obsessive-Compulsive DisorderDiagnosis and Treatment of Obsessive-Compulsive Disorder. JAMA 317(13): 1358-1367.

Hoffmann, C., M. Dietrich, et al. (2017). Dimethyl Fumarate Induces Glutathione Recycling by Upregulation of Glutathione Reductase. Oxidative Medicine and Cellular Longevity 2017: 8 .

Holmay, M. J., M. Terpstra, et al. (2013). N-acetylcysteine Boosts Brain and Blood Glutathione in Gaucher and Parkinson Diseases. Clinical Neuropharmacology 36(4): 103-106.

Hou, I.-C., C. Suzuki, et al. (2011). $\beta$-Lactotensin derived from bovine $\beta$-lactoglobulin exhibits anxiolytic-like activity as an agonist for neurotensin NTS2 receptor via 
activation of dopamine D1 receptor in mice. Journal of Neurochemistry 119(4): 785790.

Hovatta, I., R. S. Tennant, et al. (2005). Glyoxalase 1 and glutathione reductase 1 regulate anxiety in mice. Nature 438(7068): 662-666.

Huang, H.-C., T. Nguyen, et al. (2000). Regulation of the antioxidant response element by protein kinase C-mediated phosphorylation of NF-E2-related factor 2. Proceedings of the National Academy of Sciences 97(23): 12475-12480.

Hussien, N. I., H. S. El-Wakeel, et al. (2019). Alleviation of cardiac mitochondrial dysfunction and oxidative stress underlies the protective effect of vitamin D in chronic stress-induced cardiac dysfunction in rats. Gen Physiol Biophys 38(1): 51-61.

Huxtable, R. J. (1989). Taurine in the central nervous system and the mammalian actions of taurine. Progress in Neurobiology 32(6): 471-533.

Huxtable, R. J. (1992). Physiological actions of taurine. Physiological Reviews 72(1): 101163.

Idrissi, A. E., L. Boukarrou, et al. (2009). Effects of Taurine on Anxiety-Like and Locomotor Behavior of Mice, New York, NY, Springer New York.

Ighodaro, O. M. (2018). Molecular pathways associated with oxidative stress in diabetes mellitus. Biomedicine \& Pharmacotherapy 108: 656-662.

Inoue, M. (2016). Glutathionists in the battlefield of gamma-glutamyl cycle. Arch Biochem Biophys 595: 61-63.

Irie, M., M. Miyata, et al. (2005). Depression and possible cancer risk due to oxidative DNA damage. J Psychiatr Res 39(6): 553-560.

Ishii, T. and E. Warabi (2019). Mechanism of Rapid Nuclear Factor-E2-Related Factor 2 (Nrf2) Activation via Membrane-Associated Estrogen Receptors: Roles of NADPH Oxidase 1, Neutral Sphingomyelinase 2 and Epidermal Growth Factor Receptor (EGFR). Antioxidants 8(3): 69.

Itoh, K., T. Chiba, et al. (1997). An Nrf2/Small Maf Heterodimer Mediates the Induction of Phase II Detoxifying Enzyme Genes through Antioxidant Response Elements. Biochemical and Biophysical Research Communications 236(2): 313-322.

Itoh, K., N. Wakabayashi, et al. (1999). Keap1 represses nuclear activation of antioxidant responsive elements by Nrf2 through binding to the amino-terminal Neh2 domain. Genes \& Development 13(1): 76-86.

Itoh, K., N. Wakabayashi, et al. (2003). Keap1 regulates both cytoplasmic-nuclear shuttling and degradation of Nrf2 in response to electrophiles. Genes to Cells 8(4): 379-391.

Jaatinen, N., R. Korpela, et al. (2014). Effects of daily intake of yoghurt enriched with bioactive components on chronic stress responses: a double-blinded randomized controlled trial AU - Jaatinen, Nora. International Journal of Food Sciences and Nutrition 65(4): 507-514.

Jacob, K. D., N. Noren Hooten, et al. (2013). Markers of oxidant stress that are clinically relevant in aging and age-related disease. Mech Ageing Dev 134(3-4): 139-157.

Jagatha, B., R. B. Mythri, et al. (2008). Curcumin treatment alleviates the effects of glutathione depletion in vitro and in vivo: Therapeutic implications for Parkinson's disease explained via in silico studies. Free Radical Biology and Medicine 44(5): 907917.

James, M. I., C. Iwuji, et al. (2015). Curcumin inhibits cancer stem cell phenotypes in ex vivo models of colorectal liver metastases, and is clinically safe and tolerable in combination with FOLFOX chemotherapy. Cancer Letters 364(2): 135-141.

Janáky, R., C. A. Shaw, et al. (2008). Taurine release in developing mouse hippocampus is modulated by glutathione and glutathione derivatives. Amino Acids 34(1): 75-80. 
Jayaraj, R. L., N. Elangovan, et al. (2014). CNB-001 a Novel Curcumin Derivative, Guards Dopamine Neurons in MPTP Model of Parkinson\&\#x2019;s Disease. BioMed Research International 2014: 11.

Jia, N., Q. Sun, et al. (2016). Taurine promotes cognitive function in prenatally stressed juvenile rats via activating the Akt-CREB-PGC1 $\alpha$ pathway. Redox Biology 10: 179190.

Kaida, S., Y. Ohta, et al. (2010). Protective effect of L-ascorbic acid against oxidative damage in the liver of rats with water-immersion restraint stress. Redox Rep 15(1): 11-19.

Kalaz, E. B., B. Evran, et al. (2012). Effect of carnosine on prooxidant-antioxidant balance in several tissues of rats exposed to chronic cold plus immobilization stress. J Pharmacol Sci 120(2): 98-104.

Kandar, R., X. Stramova, et al. (2015). Determination of Total Glutathione in Dried Blood Spot Samples Using a High-Performance Liquid Chromatography. J Chromatogr Sci 53(6): 879-885.

Kang, D., D. Zhao, et al. (2020). Perceived stress and non-alcoholic fatty liver disease in apparently healthy men and women. Sci Rep 10(1): 38 .

Kato, Y., Y. Kubo, et al. (2010). Gene Knockout and Metabolome Analysis of Carnitine/Organic Cation Transporter OCTN1. Pharmaceutical Research 27(5): 832840.

Katoh, Y., K. Itoh, et al. (2001). Two domains of Nrf2 cooperatively bind CBP, a CREB binding protein, and synergistically activate transcription. Genes to Cells 6(10): 857868.

Kaufman, M. J., A. P. Prescot, et al. (2009). Oral glycine administration increases brain glycine/creatine ratios in men: A proton magnetic resonance spectroscopy study. Psychiatry Research: Neuroimaging 173(2): 143-149.

Kerasioti, E., D. Stagos, et al. (2018). Effects of sheep/goat whey protein dietary supplementation on the redox status of rats. Molecular Medicine Reports 17: 8 .

Keshavarz-Bahaghighat, H., M. R. Sepand, et al. (2018). Acetyl-1-Carnitine Attenuates Arsenic-Induced Oxidative Stress and Hippocampal Mitochondrial Dysfunction. Biological Trace Element Research 184(2): 422-435.

Keum, Y.-S. (2012). Regulation of Nrf2-Mediated Phase II Detoxification and Anti-oxidant Genes. Biomolecules \& therapeutics 20(2): 144-151.

Keum, Y.-S., E. D. Owuor, et al. (2003). Involvement of Nrf2 and JNK1 in the Activation of Antioxidant Responsive Element (ARE) by Chemopreventive Agent Phenethyl Isothiocyanate (PEITC). Pharmaceutical Research 20(9): 1351-1356.

Keum, Y.-S., S. Yu, et al. (2006). Mechanism of Action of Sulforaphane: Inhibition of p38 Mitogen-Activated Protein Kinase Isoforms Contributing to the Induction of Antioxidant Response Element-Mediated Heme Oxygenase-1 in Human Hepatoma HepG2 Cells. Cancer Research 66(17): 8804-8813.

Khatri, D. K. and A. R. Juvekar (2016). Neuroprotective effect of curcumin as evinced by abrogation of rotenone-induced motor deficits, oxidative and mitochondrial dysfunctions in mouse model of Parkinson's disease. Pharmacology Biochemistry and Behavior 150-151: 39-47.

Kim, J., K. M. Kim, et al. (2012). Puerarin inhibits the retinal pericyte apoptosis induced by advanced glycation end products in vitro and in vivo by inhibiting NADPH oxidaserelated oxidative stress. Free Radical Biology and Medicine 53(2): 357-365.

Kim, S. H., D. S. Oh, et al. (2016). Silymarin Prevents Restraint Stress-Induced Acute Liver Injury by Ameliorating Oxidative Stress and Reducing Inflammatory Response. Molecules 21(4): 443. 
Kong, W. X., S. W. Chen, et al. (2006). Effects of taurine on rat behaviors in three anxiety models. Pharmacology Biochemistry and Behavior 83(2): 271-276.

Kotler, B. M., J. E. Kerstetter, et al. (2015). The Effect of a Whey Protein Supplement on Bone Mass in Older Caucasian Adults. The Journal of Clinical Endocrinology \& Metabolism 100(6): 2214-2222.

Kour, K. and S. Bani (2011). Chicoric acid regulates behavioral and biochemical alterations induced by chronic stress in experimental Swiss albino mice. Pharmacol Biochem Behav 99(3): 342-348.

Krämer, T., T. Grob, et al. (2017). Dimethyl fumarate treatment after traumatic brain injury prevents depletion of antioxidative brain glutathione and confers neuroprotection. Journal of Neurochemistry 143(5): 523-533.

Krolow, R., D. M. Arcego, et al. (2014). Oxidative imbalance and anxiety disorders. Current neuropharmacology 12(2): 193-204.

Krömer, S. A., M. S. Keßler, et al. (2005). Identification of Glyoxalase-I as a Protein Marker in a Mouse Model of Extremes in Trait Anxiety. The Journal of Neuroscience 25(17): 4375-4384.

Kuloglu, M., M. Atmaca, et al. (2002a). Antioxidant Enzyme Activities and Malondialdehyde Levels in Patients with Obsessive-Compulsive Disorder. Neuropsychobiology 46(1): 27-32.

Kuloglu, M., M. Atmaca, et al. (2002b). Antioxidant Enzyme and Malondialdehyde Levels in Patients with Panic Disorder. Neuropsychobiology 46(4): 186-189.

Lagraauw, H. M., J. Kuiper, et al. (2015). Acute and chronic psychological stress as risk factors for cardiovascular disease: Insights gained from epidemiological, clinical and experimental studies. Brain Behav Immun 50: 18-30.

Lambert, I. H., D. M. Kristensen, et al. (2015). Physiological role of taurine - from organism to organelle. Acta Physiologica 213(1): 191-212.

Lapidus, K. A. B., V. Gabbay, et al. (2014). In vivo 1H MRS study of potential associations between glutathione, oxidative stress and anhedonia in major depressive disorder. Neuroscience Letters 569: 74-79.

LaRowe, S. D., P. Mardikian, et al. (2006). Safety and tolerability of N-acetylcysteine in cocaine-dependent individuals. The American journal on addictions 15(1): 105-110.

Lavoie, S., Y. Chen, et al. (2009). Curcumin, quercetin, and tBHQ modulate glutathione levels in astrocytes and neurons: importance of the glutamate cysteine ligase modifier subunit. Journal of Neurochemistry 108(6): 1410-1422.

Lee, D. S., H. G. Jo, et al. (2019). Antioxidant and Anti-Stress Effects of Taurine Against Electric Foot-Shock-Induced Acute Stress in Rats. Adv Exp Med Biol 1155: 185-196.

Lee, J., D.-G. Jo, et al. (2014). Adaptive Cellular Stress Pathways as Therapeutic Targets of Dietary Phytochemicals: Focus on the Nervous System. Pharmacological Reviews 66(3): 815-868.

Lehmann, J. C. U., J. J. Listopad, et al. (2007). Dimethylfumarate Induces Immunosuppression via Glutathione Depletion and Subsequent Induction of Heme Oxygenase 1. Journal of Investigative Dermatology 127(4): 835-845.

Li, C., Z. Pan, et al. (2014). Puerarin induces the upregulation of glutathione levels and nuclear translocation of Nrf2 through PI3K/Akt/GSK-3 $\beta$ signaling events in PC12 cells exposed to lead. Neurotoxicology and Teratology 46: 1-9.

Liang, S., T. Wang, et al. (2015). Administration of Lactobacillus helveticus NS8 improves behavioral, cognitive, and biochemical aberrations caused by chronic restraint stress. Neuroscience 310: 561-577. 
Linker, R. A., D.-H. Lee, et al. (2011). Fumaric acid esters exert neuroprotective effects in neuroinflammation via activation of the Nrf2 antioxidant pathway. Brain 134(3): 678692.

Liu, H., L. E. Harrell, et al. (2005). Gender differences in glutathione metabolism in Alzheimer's disease. Journal of Neuroscience Research 79(6): 861-867.

Liu, K., M.-J. Jing, et al. (2019). Effect of trehalose on manganese-induced mitochondrial dysfunction and neuronal cell damage in mice. Basic \& Clinical Pharmacology \& Toxicology 125(6): 536-547.

Liu, M., M. Zhang, et al. (2013). Multiple toxicity studies of trehalose in mice by intragastric administration. Food Chemistry 136(2): 485-490.

Lopez-Lopez, A. L., H. B. Jaime, et al. (2016). Chronic unpredictable mild stress generates oxidative stress and systemic inflammation in rats. Physiol Behav 161: 15-23.

Lopresti, A. L. and P. D. Drummond (2017). Efficacy of curcumin, and a saffron/curcumin combination for the treatment of major depression: A randomised, double-blind, placebo-controlled study. Journal of Affective Disorders 207: 188-196.

Maes, M., P. Galecki, et al. (2011). A review on the oxidative and nitrosative stress (O\&NS) pathways in major depression and their possible contribution to the (neuro)degenerative processes in that illness. Progress in Neuro-Psychopharmacology and Biological Psychiatry 35(3): 676-692.

Mahdy, H. M., M. R. Mohamed, et al. (2014). Puerarin Ameliorates 3-Nitropropionic AcidInduced Neurotoxicity in Rats: Possible Neuromodulation and Antioxidant Mechanisms. Neurochemical Research 39(2): 321-332.

Mayer, M. L., M. Benveniste, et al. (1992). Pharmacologic Properties of NMDA Receptors. Annals of the New York Academy of Sciences 648(1): 194-204.

McCord, J. M. (1974). Free Radicals and Inflammation: Protection of Synovial Fluid by Superoxide Dismutase. Science 185(4150): 529-531.

McEwen, B. S. (2017). Neurobiological and Systemic Effects of Chronic Stress. Chronic stress (Thousand Oaks, Calif.) 1: 10.1177/2470547017692328.

McIntosh, L. J., K. E. Hong, et al. (1998). Glucocorticoids may alter antioxidant enzyme capacity in the brain: baseline studies. Brain Research 791(1): 209-214.

McMahon, M., D. J. Lamont, et al. (2010). Keap1 perceives stress via three sensors for the endogenous signaling molecules nitric oxide, zinc, and alkenals. Proceedings of the National Academy of Sciences 107(44): 18838-18843.

Meister, A. (1991). Glutathione deficiency produced by inhibition of its synthesis, and its reversal; Applications in research and therapy. Pharmacology \& Therapeutics 51(2): 155-194.

Mezzomo, N. J., B. D. Fontana, et al. (2019). Taurine modulates the stress response in zebrafish. Hormones and Behavior 109: 44-52.

Mezzomo, N. J., A. Silveira, et al. (2016). The role of taurine on anxiety-like behaviors in zebrafish: A comparative study using the novel tank and the light-dark tasks. Neuroscience Letters 613: 19-24.

Micke, P., K. M. Beeh, et al. (2001). Oral supplementation with whey proteins increases plasma glutathione levels of HIV-infected patients. European Journal of Clinical Investigation 31(2): 171-178.

Mischley, L. K. (2017). Chapter Forty - Nutrition and Nonmotor Symptoms of Parkinson's Disease. International Review of Neurobiology. K. R. Chaudhuri and N. Titova, Academic Press. 134: 1143-1161.

Mischley, L. K., K. E. Conley, et al. (2016). Central nervous system uptake of intranasal glutathione in Parkinson's disease. Npj Parkinson\&\#39;S Disease 2: 16002. 
Mishra, A., I. Reddy, et al. (2016). 1-carnitine Mediated Reduction in Oxidative Stress and Alteration in Transcript Level of Antioxidant Enzymes in Sheep Embryos Produced In Vitro. Reproduction in Domestic Animals 51(2): 311-321.

Mizui, T., H. Kinouchi, et al. (1992). Depletion of brain glutathione by buthionine sulfoximine enhances cerebral ischemic injury in rats. American Journal of Physiology-Heart and Circulatory Physiology 262(2): H313-H317.

Mizuno, K., T. Kume, et al. (2011). Glutathione Biosynthesis via Activation of the Nuclear Factor E2\&ndash;Related Factor 2 (Nrf2) \&ndash; Antioxidant-Response Element (ARE) Pathway Is Essential for Neuroprotective Effects of Sulforaphane and 6(Methylsulfinyl) Hexyl Isothiocyanate. Journal of Pharmacological Sciences advpub: 1102230521-1102230521.

Mizunoe, Y., M. Kobayashi, et al. (2018). Trehalose protects against oxidative stress by regulating the Keap1-Nrf2 and autophagy pathways. Redox Biology 15: 115-124.

Mocelin, R., A. P. Herrmann, et al. (2015). N-acetylcysteine prevents stress-induced anxiety behavior in zebrafish. Pharmacology Biochemistry and Behavior 139: 121-126.

Mocelin, R., M. Marcon, et al. (2018). N-Acetylcysteine Reverses Anxiety and Oxidative Damage Induced by Unpredictable Chronic Stress in Zebrafish. Molecular Neurobiology.

Mohmmad Abdul, H. and D. A. Butterfield (2007). Involvement of PI3K/PKG/ERK1/2 signaling pathways in cortical neurons to trigger protection by cotreatment of acetylL-carnitine and $\alpha$-lipoic acid against HNE-mediated oxidative stress and neurotoxicity: Implications for Alzheimer's disease. Free Radical Biology and Medicine 42(3): 371-384.

Möller, M., J. L. Du Preez, et al. (2011). Isolation rearing-induced deficits in sensorimotor gating and social interaction in rats are related to cortico-striatal oxidative stress, and reversed by sub-chronic clozapine administration. European Neuropsychopharmacology 21(6): 471-483.

Morava, É. and T. Kozicz (2013). Mitochondria and the economy of stress (mal)adaptation. Neuroscience \& Biobehavioral Reviews 37(4): 668-680.

Murphy, Michael P. (2009). How mitochondria produce reactive oxygen species. Biochemical Journal 417(1): 1-13.

Nagar, R., A. R. Khan, et al. (2015). Metabolism of cisplatin in the organs of Rattus norvegicus: role of Glutathione S-transferase P1. European Journal of Drug Metabolism and Pharmacokinetics 40(1): 45-51.

Nakamichi, N. and Y. Kato (2017). Physiological Roles of Carnitine/Organic Cation Transporter OCTN1/SLC22A4 in Neural Cells. Biological and Pharmaceutical Bulletin 40(8): 1146-1152.

Nakamichi, N., K. Nakayama, et al. (2016). Food-derived hydrophilic antioxidant ergothioneine is distributed to the brain and exerts antidepressant effect in mice. Brain and Behavior 6(6): e00477.

Nakamichi, N., T. Taguchi, et al. (2012). Functional expression of carnitine/organic cation transporter OCTN1 in mouse brain neurons: Possible involvement in neuronal differentiation. Neurochemistry International 61(7): 1121-1132.

Nakamura, T., S. Sugiura, et al. (2007). Decreased Proliferation and Erythroid Differentiation of K562 Cells by siRNA-induced Depression of OCTN1 (SLC22A4) Transporter Gene. Pharmaceutical Research 24(9): 1628-1635.

Narasimhan, M., L. Mahimainathan, et al. (2011). Overexpression of Nrf2 Protects Cerebral Cortical Neurons from Ethanol-Induced Apoptotic Death. Molecular Pharmacology 80(6): 988-999. 
Negi, G., A. Kumar, et al. (2010). Functional and biochemical evidence indicating beneficial effect of Melatonin and Nicotinamide alone and in combination in experimental diabetic neuropathy. Neuropharmacology 58(3): 585-592.

Ngamchuea, K., C. Batchelor-McAuley, et al. (2017). Rapid Method for the Quantification of Reduced and Oxidized Glutathione in Human Plasma and Saliva. Anal Chem 89(5): 2901-2908.

Nie, L., G. Wei, et al. (2017). Melatonin ameliorates anxiety and depression-like behaviors and modulates proteomic changes in triple transgenic mice of Alzheimer's disease. BioFactors 43(4): 593-611.

Nie, X., D. W. Lowe, et al. (2016). Sex-specific effects of N-acetylcysteine in neonatal rats treated with hypothermia after severe hypoxia-ischemia. Neuroscience Research 108: 24-33.

Niedzielska, E., I. Smaga, et al. (2016). Oxidative Stress in Neurodegenerative Diseases. Molecular Neurobiology 53(6): 4094-4125.

Nousen, E. K., J. G. Franco, et al. (2013). Unraveling the mechanisms responsible for the comorbidity between metabolic syndrome and mental health disorders. Neuroendocrinology 98(4): 254-266.

Novelli, E. L. B., P. P. Santos, et al. (2009). N-acetylcysteine in high-sucrose diet-induced obesity: Energy expenditure and metabolic shifting for cardiac health. Pharmacological Research 59(1): 74-79.

Ohta, Y., S. Chiba, et al. (2007). Development of oxidative stress and cell damage in the liver of rats with water-immersion restraint stress. Redox Rep 12(3): 139-147.

Orlowski, M. and A. Meister (1971). Isolation of highly purified gamma-glutamylcysteine synthetase from rat kidney. Biochemistry 10(3): 372-380.

Otsuka, T., R. Goda, et al. (2015). Dietary protein ingested before and during short photoperiods makes an impact on affect-related behaviours and plasma composition of amino acids in mice. British Journal of Nutrition 114(10): 1734-1743.

Ozacmak, V. H. and H. Sayan (2009). The effects of 17beta estradiol, 17alpha estradiol and progesterone on oxidative stress biomarkers in ovariectomized female rat brain subjected to global cerebral ischemia. Physiological research 58(6): 909-912.

Ozdemir, O., Y. Selvi, et al. (2012). Comparison of Superoxide Dismutase, Glutathione Peroxidase and Adenosine Deaminase Activities between Respiratory and Nocturnal Subtypes of Patients with Panic Disorder. Neuropsychobiology 66(4): 244-251.

Pajović, S. B., Z. S. Saicić, et al. (2003). The effect of ovarian hormones on antioxidant enzyme activities in the brain of male rats. Physiological research 52(2): 189-194.

Palta, P., L. J. Samuel, et al. (2014). Depression and oxidative stress: results from a metaanalysis of observational studies. Psychosom Med 76(1): 12-19.

Pancotto, L., R. Mocelin, et al. (2018). Anxiolytic and anti-stress effects of acute administration of acetyl-L-carnitine in zebrafish. PeerJ 6: e5309.

Park, E. J., S. M. Woo, et al. (2014). Transcriptional and post-translational regulation of Bim controls apoptosis in melatonin-treated human renal cancer Caki cells. Journal of Pineal Research 56(1): 97-106.

Patel, R., L. McIntosh, et al. (2002). Disruptive effects of glucocorticoids on glutathione peroxidase biochemistry in hippocampal cultures. Journal of Neurochemistry 82(1): 118-125.

Peña-Bautista, C., E. Casas-Fernández, et al. (2020). Stress and neurodegeneration. Clinica Chimica Acta 503: 163-168.

Perić, I., A. Stanisavljević, et al. (2017). Fluoxetine reverses behavior changes in socially isolated rats: role of the hippocampal GSH-dependent defense system and proinflammatory cytokines. Eur Arch Psychiatry Clin Neurosci 267(8): 737-749. 
Pettegrew, J. W., J. Levine, et al. (2000). Acetyl-L-carnitine physical-chemical, metabolic, and therapeutic properties: relevance for its mode of action in Alzheimer's disease and geriatric depression. Molecular Psychiatry 5(6): 616-632.

Pfeiffer, C., T. Bauer, et al. (2011). Cyanobacteria produce high levels of ergothioneine. Food Chemistry 129(4): 1766-1769.

Phillips, J. T., R. Fox, et al. (2013). Safety and Tolerability of Oral BG-12 (Dimethyl Fumarate) in Relapsing-Remitting Multiple Sclerosis (RRMS): Interim Results from ENDORSE Extension Study (P01.162). Neurology 80(7 Supplement): P01.162P101.162.

Picard, M., B. S. McEwen, et al. (2018). An energetic view of stress: Focus on mitochondria. Frontiers in Neuroendocrinology 49: 72-85.

Porcu, M., M. R. Urbano, et al. (2018). Effects of adjunctive N-acetylcysteine on depressive symptoms: Modulation by baseline high-sensitivity C-reactive protein. Psychiatry Research 263: 268-274.

Portbury, S. D., D. J. Hare, et al. (2017). Trehalose Improves Cognition in the Transgenic Tg2576 Mouse Model of Alzheimer's Disease. Journal of Alzheimer's disease : JAD 60(2): 549-560.

Prado, E., M. Maes, et al. (2015). N-acetylcysteine for therapy-resistant tobacco use disorder: a pilot study. Redox Report 20(5): 215-222.

Pulido-Moran, M., J. Moreno-Fernandez, et al. (2016). Curcumin and Health. Molecules 21(3): 264.

Rahmeier, F. L., L. S. Zavalhia, et al. (2016). The effect of taurine and enriched environment on behaviour, memory and hippocampus of diabetic rats. Neuroscience Letters 630: 84-92.

Rajput, P., A. Jangra, et al. (2017). Alcohol aggravates stress-induced cognitive deficits and hippocampal neurotoxicity: Protective effect of melatonin. Biomedicine \& Pharmacotherapy 91: 457-466.

Rappeneau, V., A. Blaker, et al. (2016). Disruption of the Glutamate-Glutamine Cycle Involving Astrocytes in an Animal Model of Depression for Males and Females. Front Behav Neurosci 10(231).

Razak, M. A., P. S. Begum, et al. (2017). Multifarious Beneficial Effect of Nonessential Amino Acid, Glycine: A Review. Oxidative Medicine and Cellular Longevity 2017: 8.

Reeve, A. K., K. J. Krishnan, et al. (2011). Mitochondrial dysfunction in neurodegenerative disorders, Springer Science \& Business Media.

Reyes, R. C., G. F. Cittolin-Santos, et al. (2016). Neuronal Glutathione Content and Antioxidant Capacity can be Normalized In Situ by N-acetyl Cysteine Concentrations Attained in Human Cerebrospinal Fluid. Neurotherapeutics 13(1): 217-225.

Richards, A. B., S. Krakowka, et al. (2002). Trehalose: a review of properties, history of use and human tolerance, and results of multiple safety studies. Food and Chemical Toxicology 40(7): 871-898.

Richman, P. G. and A. Meister (1975a). Regulation of gamma-glutamyl-cysteine synthetase by nonallosteric feedback inhibition by glutathione. Journal of Biological Chemistry 250(4): 1422-1426.

Richman, P. G. and A. Meister (1975b). Regulation of gamma-glutamyl-cysteine synthetase by nonallosteric feedback inhibition by glutathione. J Biol Chem 250(4): 1422-1426.

Ringman, J. M., S. A. Frautschy, et al. (2012). Oral curcumin for Alzheimer's disease: tolerability and efficacy in a 24-week randomized, double blind, placebo-controlled study. Alzheimer's Research \& Therapy 4(5): 43. 
Ripps, H. and W. Shen (2012). Review: taurine: a "very essential" amino acid. Molecular vision 18: 2673-2686.

Rodríguez-Navarro, J. A., L. Rodríguez, et al. (2010). Trehalose ameliorates dopaminergic and tau pathology in parkin deleted/tau overexpressing mice through autophagy activation. Neurobiology of Disease 39(3): 423-438.

Ross, E. K., A. N. Winter, et al. (2014). A Cystine-Rich Whey Supplement (Immunocal ${ }^{\circledR}$ ) Delays Disease Onset and Prevents Spinal Cord Glutathione Depletion in the hSOD1G93A Mouse Model of Amyotrophic Lateral Sclerosis. Antioxidants 3(4): 843-865.

Rossi, R., A. Milzani, et al. (2002). Blood glutathione disulfide: in vivo factor or in vitro artifact? Clin Chem 48(5): 742-753.

Ruksee, N., W. Tongjaroenbuangam, et al. (2014). Melatonin pretreatment prevented the effect of dexamethasone negative alterations on behavior and hippocampal neurogenesis in the mouse brain. The Journal of Steroid Biochemistry and Molecular Biology 143: 72-80.

Russ, T. C., M. Kivimaki, et al. (2015). Association Between Psychological Distress and Liver Disease Mortality: A Meta-analysis of Individual Study Participants. Gastroenterology 148(5): 958-966 e954.

Salim, S., N. Sarraj, et al. (2010). Moderate treadmill exercise prevents oxidative stressinduced anxiety-like behavior in rats. Behavioural Brain Research 208(2): 545-552.

Samarghandian, S., M. Azimi-Nezhad, et al. (2017a). Protective effects of carnosol against oxidative stress induced brain damage by chronic stress in rats. BMC complementary and alternative medicine 17(1): 249-249.

Samarghandian, S., M. Azimi-Nezhad, et al. (2017b). Anti-oxidative effects of curcumin on immobilization-induced oxidative stress in rat brain, liver and kidney. Biomed Pharmacother 87: 223-229.

Samarghandian, S., T. Farkhondeh, et al. (2016). Protective Effects of Carvacrol against Oxidative Stress Induced by Chronic Stress in Rat's Brain, Liver, and Kidney. Biochem Res Int 2016: 2645237.

Sandhir, R., A. Yadav, et al. (2014). Curcumin Nanoparticles Attenuate Neurochemical and Neurobehavioral Deficits in Experimental Model of Huntington's Disease. NeuroMolecular Medicine 16(1): 106-118.

Sanmukhani, J., V. Satodia, et al. (2014). Efficacy and Safety of Curcumin in Major Depressive Disorder: A Randomized Controlled Trial. Phytotherapy Research 28(4): 579-585.

Santos, P., A. P. Herrmann, et al. (2017). Anxiolytic properties of N-acetylcysteine in mice. Behavioural Brain Research 317: 461-469.

Sato, M. and M. P. Stryker (2010). Genomic imprinting of experience-dependent cortical plasticity by the ubiquitin ligase gene Ube3a. Proceedings of the National Academy of Sciences 107(12): 5611-5616.

Schauss, A. G., A. Vértesi, et al. (2010). Evaluation of the safety of the dietary antioxidant ergothioneine using the bacterial reverse mutation assay. Toxicology 278(1): 39-45.

Scherz-Shouval, R., E. Shvets, et al. (2007). Reactive oxygen species are essential for autophagy and specifically regulate the activity of Atg4. The EMBO Journal 26(7): 1749-1760.

Schmitt, B., M. Vicenzi, et al. (2015). Effects of N-acetylcysteine, oral glutathione (GSH) and a novel sublingual form of GSH on oxidative stress markers: A comparative crossover study. Redox Biology 6: 198-205. 
Schmitt, M. L., W. Coelho, et al. (1995). Anxiogenic-like effect of glycine and d-serine microinjected into dorsal periaqueductal gray matter of rats. Neuroscience Letters 189(2): 93-96.

Sechi, G., M. G. Deledda, et al. (1996). Reduced intravenous glutathione in the treatment of early parkinson's disease. Progress in Neuro-Psychopharmacology and Biological Psychiatry 20(7): 1159-1170.

Sedlak, T. W., L. G. Nucifora, et al. (2017). Sulforaphane Augments Glutathione and Influences Brain Metabolites in Human Subjects: A Clinical Pilot Study. Molecular Neuropsychiatry 3(4): 214-222.

Sedlak, T. W., B. D. Paul, et al. (2019). The glutathione cycle shapes synaptic glutamate activity. Proceedings of the National Academy of Sciences 116(7): 2701-2706.

Sekhar, R. V., S. V. McKay, et al. (2011). Glutathione Synthesis Is Diminished in Patients With Uncontrolled Diabetes and Restored by Dietary Supplementation With Cysteine and Glycine. Diabetes Care 34(1): 162-167.

Sekhar, R. V., S. G. Patel, et al. (2011). Deficient synthesis of glutathione underlies oxidative stress in aging and can be corrected by dietary cysteine and glycine supplementation 1-4. The American Journal of Clinical Nutrition 94(3): 847-853.

Seo, J.-S., J.-Y. Park, et al. (2012). NADPH Oxidase Mediates Depressive Behavior Induced by Chronic Stress in Mice. The Journal of Neuroscience 32(28): 9690-9699.

Sepehrmanesh, Z., M. Heidary, et al. (2018). Therapeutic effect of adjunctive N-acetyl cysteine (NAC) on symptoms of chronic schizophrenia: A double-blind, randomized clinical trial. Progress in Neuro-Psychopharmacology and Biological Psychiatry 82: 289-296.

Serra, M., M. G. Pisu, et al. (2005). Social isolation-induced changes in the hypothalamicpituitary-adrenal axis in the rat. Stress 8(4): 259-264.

Shao, A. and J. N. Hathcock (2008). Risk assessment for the amino acids taurine, l-glutamine and 1-arginine. Regulatory Toxicology and Pharmacology 50(3): 376-399.

Shao, Y., G. Yan, et al. (2015). Chronic social isolation decreases glutamate and glutamine levels and induces oxidative stress in the rat hippocampus. Behavioural Brain Research 282: 201-208.

Shapiro, T. A., J. W. Fahey, et al. (2006). Safety, Tolerance, and Metabolism of Broccoli Sprout Glucosinolates and Isothiocyanates: A Clinical Phase I Study. Nutrition and Cancer 55(1): 53-62.

Shapiro, T. A., J. W. Fahey, et al. (2001). Chemoprotective Glucosinolates and Isothiocyanates of Broccoli Sprouts. Metabolism and Excretion in Humans 10(5): 501-508.

Sheikh, S. I., I. Nestorov, et al. (2013). Tolerability and Pharmacokinetics of DelayedRelease Dimethyl Fumarate Administered With and Without Aspirin in Healthy Volunteers. Clinical Therapeutics 35(10): 1582-1594.e1589.

Sheremata, W., A. D. Brown, et al. (2015). Dimethyl fumarate for treating relapsing multiple sclerosis. Expert Opinion on Drug Safety 14(1): 161-170.

Shertzer, H. G., M. Krishan, et al. (2013). Dietary whey protein stimulates mitochondrial activity and decreases oxidative stress in mouse female brain. Neuroscience Letters 548: 159-164.

Shih, A. Y., D. A. Johnson, et al. (2003). Coordinate Regulation of Glutathione Biosynthesis and Release by Nrf2-Expressing Glia Potently Protects Neurons from Oxidative Stress. The Journal of Neuroscience 23(8): 3394-3406.

Shin, H. K., J. Kim, et al. (2010). Inhibitory effect of curcumin on motility of human oral squamous carcinoma YD-10B cells via suppression of ERK and NF- $\kappa B$ activations. Phytotherapy Research 24(4): 577-582. 
Shirendeb, U., A. P. Reddy, et al. (2011). Abnormal mitochondrial dynamics, mitochondrial loss and mutant huntingtin oligomers in Huntington's disease: implications for selective neuronal damage. Hum Mol Genet 20(7): 1438-1455.

Shungu, D. C. (2012). $<\mathrm{em}>\mathrm{N}</ \mathrm{em}>$-Acetylcysteine for the Treatment of Glutathione Deficiency and Oxidative Stress in Schizophrenia. Biological Psychiatry 71(11): 937938.

Sibson, N. R., A. Dhankhar, et al. (1998). Stoichiometric coupling of brain glucose metabolism and glutamatergic neuronal activity. Proc Natl Acad Sci U S A 95(1): 316-321.

Sinha, R., I. Sinha, et al. (2018). Oral supplementation with liposomal glutathione elevates body stores of glutathione and markers of immune function. Eur J Clin Nutr 72(1): 105-111.

Sirdah, M. M., I. M. A. El-Agouza, et al. (2002). Possible ameliorative effect of taurine in the treatment of iron-deficiency anaemia in female university students of Gaza, Palestine. European Journal of Haematology 69(4): 236-242.

Smedberg, M. and J. Wernerman (2016). Is the glutamine story over? Critical Care 20(1): 361.

Snoke, J. E. (1955). Isolation and properties of yeast glutathione synthetase. J Biol Chem 213(2): 813-824.

Sobočanec, S., T. Balog, et al. (2003). Sex-dependent Antioxidant Enzyme Activities and Lipid Peroxidation in Ageing Mouse Brain. Free Radical Research 37(7): 743-748.

Solanki, N., A. Salvi, et al. (2017). Modulating Oxidative Stress Relieves Stress-Induced Behavioral and Cognitive Impairments in Rats. International Journal of Neuropsychopharmacology 20(7): 550-561.

Song, T.-Y., H. C. Lin, et al. (2014). Ergothioneine and melatonin attenuate oxidative stress and protect against learning and memory deficits in C57BL/6J mice treated with Dgalactose AU - Song, T.-Y. Free Radical Research 48(9): 1049-1060.

Song, W., A. Tavitian, et al. (2017). Cysteine-rich whey protein isolate (Immunocal ${ }^{\circledR}$ ) ameliorates deficits in the GFAP.HMOX1 mouse model of schizophrenia. Free Radical Biology and Medicine 110: 162-175.

Sonnay, S., R. Gruetter, et al. (2017). How Energy Metabolism Supports Cerebral Function: Insights from 13C Magnetic Resonance Studies In vivo. Frontiers in Neuroscience 11(288).

Steele, M. L., S. Fuller, et al. (2013). Effect of Nrf2 activators on release of glutathione, cysteinylglycine and homocysteine by human U373 astroglial cells. Redox Biology 1(1): 441-445.

Stefanaki, C., P. Pervanidou, et al. (2018). Chronic stress and body composition disorders: implications for health and disease. Hormones (Athens) 17(1): 33-43.

Stefanatos, R. and A. Sanz (2018). The role of mitochondrial ROS in the aging brain. FEBS Letters 592(5): 743-758.

Stojić-Vukanić, Z., J. Kotur-Stevuljević, et al. (2018). Sex Bias in Pathogenesis of Autoimmune Neuroinflammation: Relevance for Dimethyl Fumarate Immunomodulatory/Anti-oxidant Action. Molecular Neurobiology 55(5): 3755-3774.

Strasser, A., L. Xin, et al. (2019). Nucleus accumbens neurochemistry in human anxiety: A 7 T 1H-MRS study. European Neuropsychopharmacology 29(3): 365-375.

Sturman, J. A. (1993). Taurine in development. Physiological Reviews 73(1): 119-147.

Sun, X., M. Wang, et al. (2017). Melatonin produces a rapid onset and prolonged efficacy in reducing depression-like behaviors in adult rats exposed to chronic unpredictable mild stress. Neuroscience Letters 642: 129-135. 
Sun, Z., Y. E. Chin, et al. (2009). Acetylation of Nrf2 by p300/CBP Augments PromoterSpecific DNA Binding of Nrf2 during the Antioxidant Response. Molecular and Cellular Biology 29(10): 2658-2672.

Szebeni, A., K. Szebeni, et al. (2017). Elevated DNA Oxidation and DNA Repair Enzyme Expression in Brain White Matter in Major Depressive Disorder. Int J Neuropsychopharmacol 20(5): 363-373.

Szegő, É. M., T. Janáky, et al. (2010). A mouse model of anxiety molecularly characterized by altered protein networks in the brain proteome. European Neuropsychopharmacology 20(2): 96-111.

Tang, K.-K., X.-Y. Liu, et al. (2019). Trehalose alleviates cadmium-induced brain damage by ameliorating oxidative stress, autophagy inhibition, and apoptosis. Metallomics 11(12): 2043-2051.

Tang, R. M. Y., I. K.-M. Cheah, et al. (2018). Distribution and accumulation of dietary ergothioneine and its metabolites in mouse tissues. Scientific Reports 8(1): 1601.

Taniguti, E. H., Y. S. Ferreira, et al. (2018). Neuroprotective effect of melatonin against lipopolysaccharide-induced depressive-like behavior in mice. Physiology \& Behavior 188: 270-275.

Taubert, D., G. Grimberg, et al. (2005). Functional role of the 503F variant of the organic cation transporter OCTN1 in Crohn's disease. Gut 54(10): 1505-1506.

Tempesta, E., L. Casella, et al. (1987). L-acetylcarnitine in depressed elderly subjects. A cross-over study vs placebo. Drugs Exp Clin Res 13(7): 417-423.

Tietze, F. (1969). Enzymic method for quantitative determination of nanogram amounts of total and oxidized glutathione: applications to mammalian blood and other tissues. Anal Biochem 27(3): 502-522.

Tipple, T. E. and L. K. Rogers (2012). Methods for the determination of plasma or tissue glutathione levels. Methods Mol Biol 889: 315-324.

Tosukhowong, P., C. Boonla, et al. (2016). Biochemical and clinical effects of Whey protein supplementation in Parkinson's disease: A pilot study. Journal of the Neurological Sciences 367: 162-170.

Tschirka, J., M. Kreisor, et al. (2018). Substrate Selectivity Check of the Ergothioneine Transporter. Drug Metabolism and Disposition 46(6): 779-785.

Tu, D.-G., Y.-L. Chang, et al. (2018). Preventive effects of taurine against d-galactoseinduced cognitive dysfunction and brain damage. Food \& Function 9(1): 124-133.

Umehara, H., S. Numata, et al. (2017). Altered KYN/TRP, Gln/Glu, and Met/methionine sulfoxide ratios in the blood plasma of medication-free patients with major depressive disorder. Scientific Reports 7(1): 4855.

Uysal, N., S. Gonenc, et al. (2005). Age-dependent effects of maternal deprivation on oxidative stress in infant rat brain. Neurosci Lett 384(1-2): 98-101.

Vadhan-Raj, S., D. M. Weber, et al. (2007). Curcumin Downregulates NF-kB and Related Genes in Patients with Multiple Myeloma: Results of a Phase I/II Study. Blood 110(11): 1177-1177.

van Geffen, E. C. G., S. W. van der Wal, et al. (2007). Evaluation of patients' experiences with antidepressants reported by means of a medicine reporting system. European Journal of Clinical Pharmacology 63(12): 1193-1199.

Venigalla, M., E. Gyengesi, et al. (2015). Curcumin and Apigenin - novel and promising therapeutics against chronic neuroinflammation in Alzheimer's disease. Neural regeneration research 10(8): 1181-1185.

Vohra, B. P. S. and X. Hui (2001). Taurine Protects against Carbon Tetrachloride Toxicity in the Cultured Neurons and In Vivo. Archives of Physiology and Biochemistry 109(1): 90-94. 
Walter, J. H. (1996). L-Carnitine. Archives of Disease in Childhood 74(6): 475-478.

Wang, W., Y. Lu, et al. (2015). Rapid-acting antidepressant-like effects of acetyl-1-carnitine mediated by PI3K/AKT/BDNF/VGF signaling pathway in mice. Neuroscience 285 : 281-291.

Wang, W., Z. Wu, et al. (2013). Glycine metabolism in animals and humans: implications for nutrition and health. Amino Acids 45(3): 463-477.

Wang, Z., D. Liu, et al. (2012). Cytoprotective effects of melatonin on astroglial cells subjected to palmitic acid treatment in vitro. Journal of Pineal Research 52(2): 253264.

Weissmann, G., J. E. Smolen, et al. (1980). Release of Inflammatory Mediators from Stimulated Neutrophils. New England Journal of Medicine 303(1): 27-34.

Wernerman, J. (2017). What Is Actually Attributable to Glutamine? Journal of Parenteral and Enteral Nutrition 41(1): 9-9.

Wink, L. K., R. Adams, et al. (2016). A randomized placebo-controlled pilot study of Nacetylcysteine in youth with autism spectrum disorder. Molecular Autism 7(1): 26.

Winter, A. N., E. K. Ross, et al. (2017). A Cystine-Rich Whey Supplement (Immunocal ${ }^{\circledR}$ ) Provides Neuroprotection from Diverse Oxidative Stress-Inducing Agents In Vitro by Preserving Cellular Glutathione. Oxidative Medicine and Cellular Longevity 2017: 15.

Wise, R. A., J. T. Holbrook, et al. (2016). Lack of Effect of Oral Sulforaphane Administration on Nrf2 Expression in COPD: A Randomized, Double-Blind, Placebo Controlled Trial. PLoS One 11(11): e0163716.

Witschi, A., S. Reddy, et al. (1992). The systemic availability of oral glutathione. European Journal of Clinical Pharmacology 43(6): 667-669.

Wittchen, H. U., F. Jacobi, et al. (2011). The size and burden of mental disorders and other disorders of the brain in Europe 2010. European Neuropsychopharmacology 21(9): 655-679.

Wu, G.-F., S. Ren, et al. (2017). Antidepressant effect of taurine in chronic unpredictable mild stress-induced depressive rats. Scientific Reports 7(1): 4989.

Wu, G., Z. Wu, et al. (2013). Dietary requirements of "nutritionally non-essential amino acids" by animals and humans. Amino Acids 44(4): 1107-1113.

Wu, S., Q. Gao, et al. (2016). Sulforaphane produces antidepressant- and anxiolytic-like effects in adult mice. Behavioural Brain Research 301: 55-62.

Xu, Y., D. Lin, et al. (2009). Curcumin reverses impaired cognition and neuronal plasticity induced by chronic stress. Neuropharmacology 57(4): 463-471.

Yager, S., M. J. Forlenza, et al. (2010). Depression and oxidative damage to lipids. Psychoneuroendocrinology 35(9): 1356-1362.

Yamada, A., T. Mizushige, et al. (2014). Identification of novel $\beta$-lactoglobulin-derived peptides, wheylin-1 and -2, having anxiolytic-like activity in mice. Molecular Nutrition \& Food Research 58(2): 353-358.

Yang, C., X. Zhang, et al. (2009). Curcumin upregulates transcription factor Nrf2, HO-1 expression and protects rat brains against focal ischemia. Brain Research 1282: 133 141.

Yang, N.-C., H.-C. Lin, et al. (2012). Ergothioneine protects against neuronal injury induced by $\beta$-amyloid in mice. Food and Chemical Toxicology 50(11): 3902-3911.

Yao, W., J.-c. Zhang, et al. (2016). Role of Keap1-Nrf2 signaling in depression and dietary intake of glucoraphanin confers stress resilience in mice. Scientific Reports 6: 30659.

Yeung, D. K. Y., S. W. S. Leung, et al. (2006). Puerarin, an isoflavonoid derived from Radix puerariae, potentiates endothelium-independent relaxation via the cyclic AMP 
pathway in porcine coronary artery. European Journal of Pharmacology 552(1): 105111.

Yi, W. J. and T. S. Kim (2017). Melatonin protects mice against stress-induced inflammation through enhancement of M2 macrophage polarization. Int Immunopharmacol 48: 146158.

Zafir, A. and N. Banu (2009a). Modulation of in vivo oxidative status by exogenous corticosterone and restraint stress in rats. Stress 12(2): 167-177.

Zafir, A. and N. Banu (2009b). Modulation of in vivo oxidative status by exogenous corticosterone and restraint stress in rats. Stress 12(2): 167-177.

Zaidi, S. M., T. M. Al-Qirim, et al. (2005). Effects of antioxidant vitamins on glutathione depletion and lipid peroxidation induced by restraint stress in the rat liver. Drugs R D 6(3): 157-165.

Żebrowska-Gamdzyk, M., M. Maciejczyk, et al. (2018). Whey Protein Concentrate WPC-80 Intensifies Glycoconjugate Catabolism and Induces Oxidative Stress in the Liver of Rats. Nutrients 10(9): 1178.

Zhang, D. D. and M. Hannink (2003). Distinct Cysteine Residues in Keap1 Are Required for Keap1-Dependent Ubiquitination of Nrf2 and for Stabilization of Nrf2 by Chemopreventive Agents and Oxidative Stress. Molecular and Cellular Biology 23(22): 8137-8151.

Zhang, H., H. Jay Forman, et al. (2005). $\gamma$-Glutamyl Transpeptidase in Glutathione Biosynthesis. Methods in Enzymology. H. Sies and L. Packer, Academic Press. 401: 468-483.

Zhang, Y., S.-j. Lv, et al. (2013). Effects of glycine supplementation on myocardial damage and cardiac function after severe burn. Burns 39(4): 729-735.

Zhao, Y., Q. Wang, et al. (2019). Glutamine protects against oxidative stress injury through inhibiting the activation of PI3K/Akt signaling pathway in parkinsonian cell model. Environmental Health and Preventive Medicine 24(1): 4.

Zheng, Q.-H., X.-L. Li, et al. (2017). Efficacy and safety of puerarin injection in curing acute ischemic stroke: A meta-analysis of randomized controlled trials. Medicine 96(1): e5803-e5803.

Zheng, Y., S. Tao, et al. (2012). Sulforaphane prevents pulmonary damage in response to inhaled arsenic by activating the Nrf2-defense response. Toxicology and Applied Pharmacology 265(3): 292-299.

Zhovtis Ryerson, L., R. Green, et al. (2016). Efficacy and tolerability of dimethyl fumarate in White-, African- and Hispanic- Americans with multiple sclerosis. Therapeutic Advances in Neurological Disorders 9(6): 454-461.

Zhu, Q., L. Gu, et al. (2014). The role of alpha-1 and alpha-2 adrenoceptors in restraint stress-induced liver injury in mice. PLoS One 9(3): e92125.

Zimmermann, A. K., F. A. Loucks, et al. (2007). Glutathione Binding to the Bcl-2 Homology-3 Domain Groove: A molecular basis for BCL-2 antioxidant function at mitochondria. Journal of Biological Chemistry 282(40): 29296-29304.

Zou, Y., B. Hong, et al. (2013). Protective effect of puerarin against beta-amyloid-induced oxidative stress in neuronal cultures from rat hippocampus: involvement of the GSK$3 \beta / \mathrm{Nrf2}$ signaling pathway. Free Radical Research 47(1): 55-63. 


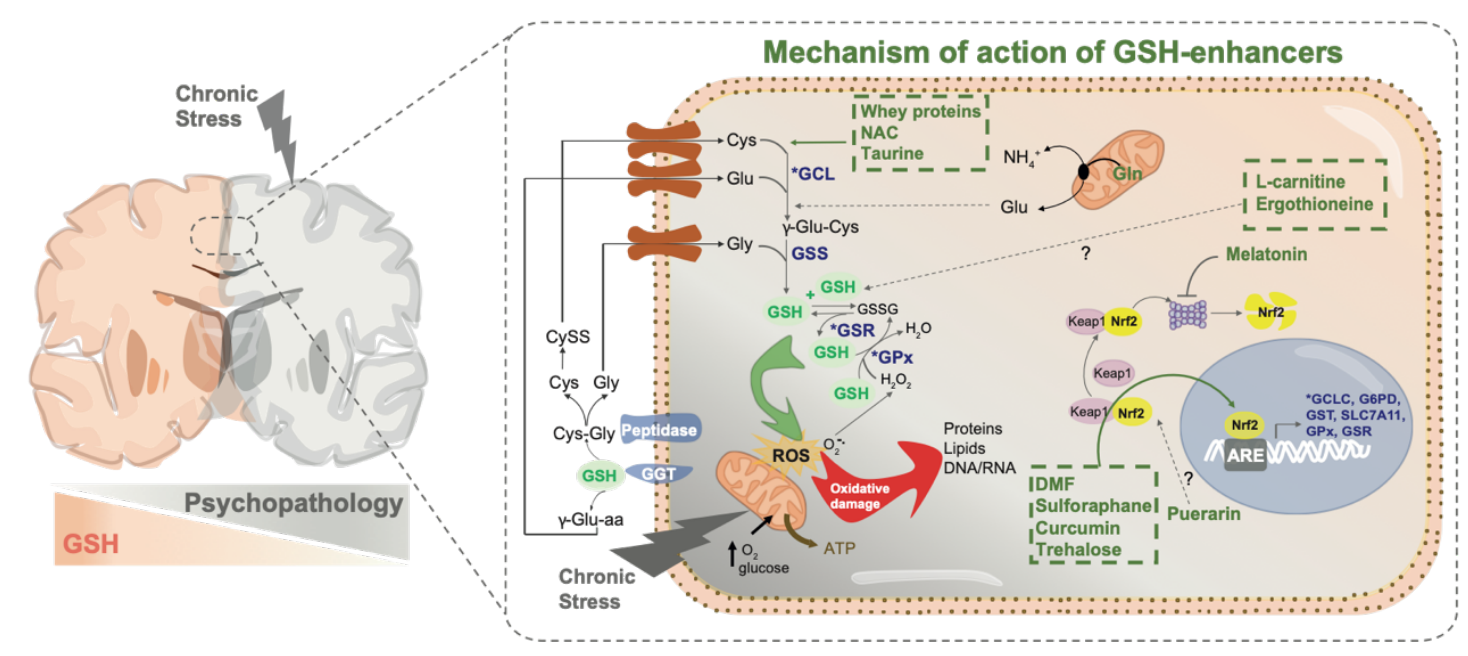

Figure 1. Strategies to enhance GSH levels in the brain in stress-induced psychopathologies

Stress-induced psychopathologies exhibit decreased GSH levels in the brain. Increased energy demand in situations of chronic stress leads to mitochondrial ROS overproduction, oxidative damage and exhaustion of GSH pools in the brain. Therefore, strategies aimed at restoring GSH levels in the brain might represent a new therapeutic option for stress-induced psychopathologies. Several compounds can function as precursors of GSH by acting as cysteine (Cys) donors such as N-acetyl-cysteine (NAC), whey proteins and taurine or glutamate (Glu) donors such as glutamine (Gln). Other compounds stimulate the synthesis and recycling of GSH through the activation of the Nrf2 pathway including sulforaphane, dimethyl fumarate (DMF), curcumin, trehalose and melatonin. Genes that are transcriptionally activated by Nrf2 include GCLC, GST, GPx, G6PD, GSR and SLC7A11 (indicated with an *). Other compounds such as ergothioneine, L-carnitine and puerarin can increase GSH levels via unknown mechanisms. Notes: $\gamma$-Glu-aa: $\gamma$-glutamyl-aminoacids; $\gamma$-Glu-Cys: $\gamma$-glutamylcysteine; ARE: antioxidant responsive element; ATP: adenosine triphosphate; Cys-Gly: cysteine-glycine dipeptides; CySS: cysteine; GCL: glutamate cysteine ligase; GCLC: glutamate cysteine ligase catalytic subunit; Gpx: glutathione peroxidase; G6PD: glucose-6-phosphate dehydrogenase; GGT: glutamyl transpeptidase; Gly: Glycine; GSH: reduced glutathione; GSR: glutathione reductase; GSS: glutamine synthetase; GSSG: oxidized glutathione; GST: glutathione S-transferase; $\mathrm{H}_{2} \mathrm{O}$ : water; $\mathrm{H}_{2} \mathrm{O}_{2}$ : hyrdrogen peroxide; Keap1: Kelch-like ECHassociated protein 1; Nrf2: nuclear factor erythroid-2-related factor 2; $\mathrm{O}_{2}$ : oxygen; $\mathrm{O}_{2}{ }^{\bullet}$ : superoxide anion; ROS: reactive oxygen species; SLC7A11: solute carrier family 7 member 11.) 


\section{Tables}

Table 1. List of GSH precursors and their impact on behavior, GSH levels and oxidative damage

\begin{tabular}{|c|c|c|c|c|c|c|}
\hline Model & $\begin{array}{l}\text { Dose and } \\
\text { route of } \\
\text { administratio } \\
n\end{array}$ & $\begin{array}{l}\text { Duration } \\
\text { treatment }\end{array}$ & $\begin{array}{l}\text { Impact on } \\
\text { behavior }\end{array}$ & $\begin{array}{l}\text { Modification } \\
\text { in GSH } \\
\text { levels }\end{array}$ & $\begin{array}{l}\text { Oxidative } \\
\text { damage }\end{array}$ & Reference \\
\hline $\begin{array}{l}\text { Zebrafish } \\
\text { Exposed to } \\
\text { acute stress }\end{array}$ & $\begin{array}{l}0.1-10 \mathrm{mg} / \mathrm{L} \text {, } \\
\text { in a water } \\
\text { beaker }\end{array}$ & $\begin{array}{l}\text { Acute } \\
\text { For } 10 \mathrm{~min} \\
\text { before } \\
\text { stress/behavi } \\
\text { oral test }\end{array}$ & $\begin{array}{l}\text { Decreased } \\
\text { acute-stress } \\
\text { induced } \\
\text { anxiety }\end{array}$ & n.a. & n.a. & $\begin{array}{l}\text { (Mocelin, } \\
\text { Herrmann et } \\
\text { al. 2015) }\end{array}$ \\
\hline $\begin{array}{l}\text { Zebrafish } \\
\text { Exposed } 14 \\
\text { days to } \\
\text { chronic } \\
\text { unpredictable } \\
\text { stress }\end{array}$ & $\begin{array}{l}1 \mathrm{mg} / \mathrm{L} \text {, in a } \\
\text { water tank }\end{array}$ & $\begin{array}{l}10 \mathrm{~min} / \text { day, } \\
\text { For the last } 7 \\
\text { days of the } \\
\text { stress period }\end{array}$ & $\begin{array}{l}\text { Decreased } \\
\text { chronic-stress } \\
\text { induced } \\
\text { anxiety }\end{array}$ & $\begin{array}{l}\text { Restored } \\
\text { chronic-stress } \\
\text { induced } \\
\text { decrease in } \\
\text { non-protein } \\
\text { thiols } \\
\text { (includes } \\
\text { GSH) (brain) }\end{array}$ & $\begin{array}{l}\text { Restored } \\
\text { chronic-stress } \\
\text { induced } \\
\text { increase in } \\
\text { ROS level } \\
\text { and lipid } \\
\text { peroxidation } \\
\text { (TBARS) } \\
\text { (brain) }\end{array}$ & $\begin{array}{l}\text { (Mocelin, } \\
\text { Marcon et al. } \\
\text { 2018) }\end{array}$ \\
\hline \multirow[t]{2}{*}{ Mice } & $\begin{array}{l}60-150 \\
\mathrm{mg} / \mathrm{Kg} \text {, i.p. }\end{array}$ & $\begin{array}{l}\text { Acute, } 1 \mathrm{~h} \\
\text { before } \\
\text { behavioral } \\
\text { test }\end{array}$ & \multirow[t]{2}{*}{$\begin{array}{l}\text { Decreased } \\
\text { anxiety }\end{array}$} & \multirow[t]{2}{*}{ n.a. } & \multirow[t]{2}{*}{ n.a. } & \multirow[t]{2}{*}{$\begin{array}{l}\text { (Santos, } \\
\text { Herrmann et } \\
\text { al. 2017) }\end{array}$} \\
\hline & $\begin{array}{l}10-100 \\
\mathrm{mg} / \mathrm{Kg} \text {, i.p. }\end{array}$ & $\begin{array}{l}\text { Daily } \\
\text { For } 4 \text { days } \\
\text { Last day, 1h } \\
\text { before } \\
\text { behavioral } \\
\text { test }\end{array}$ & & & & \\
\hline $\begin{array}{l}\text { Mice } \\
\text { Knock-out } \\
\text { for the } \\
\text { glutamate } \\
\text { transporter } \\
\text { EAAC1 }\end{array}$ & $\begin{array}{l}75 \mathrm{mg} / \mathrm{kg} \text {, i.p. } \\
\text { or, } \\
5-25 \mathrm{mg} / \mathrm{kg} \text {, } \\
\text { oral (i.g.) }\end{array}$ & $\begin{array}{l}\text { Acute, } 5 \mathrm{~h} \\
\text { before } \\
\text { harvest }\end{array}$ & n.a. & $\begin{array}{l}\text { Restored } \\
\text { GSH levels in } \\
\text { the brain } \\
\text { (hippocampu } \\
\text { s) of EAAC1- } \\
\text { /- mice }\end{array}$ & n.a. & $\begin{array}{l}\text { (Reyes, } \\
\text { Cittolin- } \\
\text { Santos et al. } \\
2016)\end{array}$ \\
\hline $\begin{array}{l}\text { Humans } \\
\text { Patients with } \\
\text { bipolar } \\
\text { disorder }\end{array}$ & $2 \mathrm{~g} /$ day, oral & $\begin{array}{l}\text { Twice daily } \\
\text { (1g) } \\
\text { For } 24 \text { weeks }\end{array}$ & $\begin{array}{l}\text { Improved } \\
\text { depression } \\
\text { rating scale } \\
\text { scores }\end{array}$ & n.a. & n.a. & $\begin{array}{l}\text { (Berk, } \\
\text { Copolov et al. } \\
\text { 2008; Berk, } \\
\text { Dean et al. } \\
2012 \text { ) }\end{array}$ \\
\hline $\begin{array}{l}\text { Humans } \\
\text { Patients with } \\
\text { major } \\
\text { depression } \\
\text { disorder }\end{array}$ & $2 \mathrm{~g} /$ day, oral & $\begin{array}{l}\text { Twice daily } \\
(1 \mathrm{~g}) \\
\text { For } 12 \text { weeks }\end{array}$ & $\begin{array}{l}\text { Improved } \\
\text { depression } \\
\text { rating scale } \\
\text { scores }\end{array}$ & n.a. & n.a. & $\begin{array}{l}\text { (Berk, Dean } \\
\text { et al. 2014; } \\
\text { Hasebe, Gray } \\
\text { et al. 2017) }\end{array}$ \\
\hline $\begin{array}{l}\text { Humans } \\
\text { Patients with } \\
\text { major } \\
\text { depression } \\
\text { disorder } \\
\end{array}$ & $\begin{array}{l}1.8 \mathrm{~g} / \text { day, } \\
\text { oral }\end{array}$ & $\begin{array}{l}\text { Daily } \\
\text { For } 12 \text { weeks }\end{array}$ & $\begin{array}{l}\text { Improved } \\
\text { depression } \\
\text { and anxiety } \\
\text { rating scales } \\
\text { scores (only } \\
\end{array}$ & n.a. & n.a. & $\begin{array}{l}\text { (Porcu, } \\
\text { Urbano et al. } \\
2018 \text { ) }\end{array}$ \\
\hline
\end{tabular}




\begin{tabular}{|c|c|c|c|c|c|c|}
\hline & & & $\begin{array}{l}\text { in patients } \\
\text { with baseline } \\
\text { high } \\
\text { sensitivity C- } \\
\text { reactive } \\
\text { protein levels } \\
\text { above } 3 \\
\text { mg/L) }\end{array}$ & & & \\
\hline $\begin{array}{l}\text { Humans } \\
\text { Patients with } \\
\text { trichotilloma } \\
\text { nia }\end{array}$ & $\begin{array}{l}2.4 \mathrm{~g} / \text { day, } \\
\text { oral }\end{array}$ & $\begin{array}{l}\text { Twice daily } \\
(1 \mathrm{~g}) \\
\text { For } 12 \text { weeks }\end{array}$ & $\begin{array}{l}\text { Improved } \\
\text { depression } \\
\text { rating scale } \\
\text { scores }\end{array}$ & n.a. & n.a. & $\begin{array}{l}\text { (Grant, } \\
\text { Odlaug et al. } \\
2009 \text { ) }\end{array}$ \\
\hline $\begin{array}{l}\text { Humans } \\
\text { Therapy- } \\
\text { resistant } \\
\text { tobacco users }\end{array}$ & $3 \mathrm{~g} /$ day, oral & $\begin{array}{l}\text { Twice daily } \\
(1.5 \mathrm{~g}) \\
\text { For } 12 \text { weeks }\end{array}$ & $\begin{array}{l}\text { Improved } \\
\text { depression } \\
\text { rating scale } \\
\text { scores } \\
\end{array}$ & n.a. & n.a. & $\begin{array}{l}\text { (Prado, Maes } \\
\text { et al. 2015) }\end{array}$ \\
\hline $\begin{array}{l}\text { Humans } \\
\text { Patients with } \\
\text { Parkinson's } \\
\text { disease }\end{array}$ & $6 \mathrm{~g} /$ day, oral & $\begin{array}{l}\text { Twice daily } \\
(3 \mathrm{~g}) \\
\text { For } 4 \text { weeks }\end{array}$ & n.a. & $\begin{array}{l}\text { Unchanged } \\
\text { GSH (brain: } \\
\text { occipital } \\
\text { cortex) } \\
\text { Increased } \\
\text { GSH/GSSG } \\
\text { ratio (plasma) }\end{array}$ & $\begin{array}{l}\text { Increased } \\
\text { catalase } \\
\text { activity }\end{array}$ & $\begin{array}{l}\text { (Coles, Tuite } \\
\text { et al. 2018) }\end{array}$ \\
\hline $\begin{array}{l}\text { Humans } \\
\text { Patients with } \\
\text { autism } \\
\text { spectrum } \\
\text { disorder } \\
\text { (diagnosed) }\end{array}$ & $\begin{array}{l}60 \\
\mathrm{mg} / \mathrm{Kg} / \mathrm{day} \text {, } \\
\text { oral }\end{array}$ & $\begin{array}{l}\text { Three divided } \\
\text { doses ( } 60 \\
\text { mg) daily } \\
\text { For } 12 \text { weeks }\end{array}$ & $\begin{array}{l}\text { No } \\
\text { significant } \\
\text { impact on } \\
\text { social } \\
\text { impairment in } \\
\text { youth with } \\
\text { autism } \\
\text { spectrum } \\
\text { disorder }\end{array}$ & $\begin{array}{l}\text { Increased } \\
\text { GSH (blood) }\end{array}$ & n.a. & $\begin{array}{l}\text { (Wink, } \\
\text { Adams et al. } \\
\text { 2016) }\end{array}$ \\
\hline \multirow[t]{2}{*}{$\begin{array}{l}\text { Humans } \\
\text { Patients with } \\
\text { schizophrenia }\end{array}$} & $\begin{array}{l}2.7 \mathrm{~g} / \text { day, } \\
\text { oral }\end{array}$ & $\begin{array}{l}\text { Twice daily } \\
(1.8 \mathrm{~g}+0.9 \\
\mathrm{g}) \\
\text { For } 6 \text { months }\end{array}$ & $\begin{array}{l}\text { Improved } \\
\text { cognitive } \\
\text { function }\end{array}$ & $\begin{array}{l}\text { Increased } \\
\text { GSH (blood } \\
\text { and brain: } \\
\text { medial } \\
\text { prefontal } \\
\text { cortex) }\end{array}$ & n.a. & $\begin{array}{l}\text { (Conus, } \\
\text { Seidman et } \\
\text { al. 2017) }\end{array}$ \\
\hline & $\begin{array}{l}1.2 \mathrm{~g} / \text { day, } \\
\text { oral }\end{array}$ & $\begin{array}{l}\text { Twice daily } \\
(0.6 \mathrm{~g}) \\
\text { For } 12 \text { weeks }\end{array}$ & $\begin{array}{l}\text { Improved } \\
\text { positive and } \\
\text { negative } \\
\text { syndrome } \\
\text { score scale } \\
\text { and cognitive } \\
\text { function }\end{array}$ & n.a. & n.a. & $\begin{array}{l}\text { (Sepehrmane } \\
\text { sh, Heidary et } \\
\text { al. 2018) }\end{array}$ \\
\hline $\begin{array}{l}\text { Humans } \\
\text { Patients with } \\
\text { Diabetes }\end{array}$ & $\begin{array}{l}1.33 \mathrm{mmol}, \\
\text { oral in } \\
\text { combination } \\
\text { with } 0.81 \\
\text { mmol NAC }\end{array}$ & $\begin{array}{l}\text { Once daily } \\
\text { For } 2 \text { weeks }\end{array}$ & n.a. & $\begin{array}{l}\text { Increased } \\
\text { GSH (blood) }\end{array}$ & $\begin{array}{l}\text { Decreased } \\
\text { ROS } \\
\text { (dROMs } \\
\text { derivatives in } \\
\text { plasma), } \\
\text { decreased } \\
\text { lipid } \\
\text { peroxides }\end{array}$ & $\begin{array}{l}\text { (Sekhar, } \\
\text { McKay et al. } \\
\text { 2011) }\end{array}$ \\
\hline
\end{tabular}




\begin{tabular}{|c|c|c|c|c|c|c|}
\hline $\begin{array}{l}\text { Humans } \\
\text { Elderly vs } \\
\text { young } \\
\text { healthy } \\
\text { subjects }\end{array}$ & $\begin{array}{l}1.33 \text { mmol, } \\
\text { oral in } \\
\text { combination } \\
\text { with } 0.81 \\
\text { mmol NAC }\end{array}$ & $\begin{array}{l}\text { Once daily } \\
\text { For } 2 \text { weeks }\end{array}$ & n.a. & $\begin{array}{l}\text { Increased } \\
\text { total GSH } \\
\text { levels, GSH } \\
\text { synthesis } \\
\text { (blood) }\end{array}$ & $\begin{array}{l}\text { Decreased } \\
\text { plasma } \\
\text { hydroperoxid } \\
\text { e and F2- } \\
\text { isoprostanes } \\
\text { in plasma } \\
\end{array}$ & $\begin{array}{l}\text { (Sekhar, Patel } \\
\text { et al. 2011) }\end{array}$ \\
\hline $\begin{array}{l}\text { Rats } \\
\text { Severe burn } \\
\text { model }\end{array}$ & $\begin{array}{l}1.5 \mathrm{~g} / \mathrm{kg} / \mathrm{day} \text {, } \\
\text { oral (i.g.) }\end{array}$ & $\begin{array}{l}\text { Once daily } \\
\text { For } 3 \text { days }\end{array}$ & n.a. & $\begin{array}{l}\text { Increased } \\
\text { GSH } \\
\text { (myocardium } \\
\text { ) }\end{array}$ & n.a. & $\begin{array}{l}\text { (Zhang, Lv et } \\
\text { al. 2013) }\end{array}$ \\
\hline Rats & $\begin{array}{l}40,60,80 \\
\text { nmol, intra- } \\
\text { PAG }\end{array}$ & Acute & $\begin{array}{l}\text { Increased } \\
\text { anxiety }\end{array}$ & n.a. & n.a. & $\begin{array}{l}\text { (Schmitt, } \\
\text { Coelho et al. } \\
\text { 1995) }\end{array}$ \\
\hline Mice & $\begin{array}{l}250-1250 \\
\mathrm{mg} / \mathrm{kg} \text {, i.p. }\end{array}$ & Acute & $\begin{array}{l}\text { Increased } \\
\text { anxiety }\end{array}$ & n.a. & n.a. & (Dolu 2007) \\
\hline $\begin{array}{l}\text { Rats } \\
\text { Streptozotoci } \\
\text { n-induced } \\
\text { diabetes } \\
\text { model }\end{array}$ & $\begin{array}{l}100 \mathrm{mg} / \mathrm{Kg} \text {, } \\
\text { i.p. }\end{array}$ & $\begin{array}{l}\text { Daily } \\
\text { For } 30 \text { days }\end{array}$ & $\begin{array}{l}\text { Improved } \\
\text { memory and } \\
\text { learning } \\
\text { performance } \\
\text { in diabetic } \\
\text { rats }\end{array}$ & n.a. & n.a. & $\begin{array}{l}\text { (Rahmeier, } \\
\text { Zavalhia et } \\
\text { al. 2016) }\end{array}$ \\
\hline $\begin{array}{l}\text { Mice } \\
\text { Aged mice } \\
\text { 18-month-old }\end{array}$ & $\begin{array}{l}0.05 \% \text {, oral } \\
\text { (drinking } \\
\text { water) }\end{array}$ & $\begin{array}{l}\text { Daily } \\
\text { For } 8 \text { months }\end{array}$ & $\begin{array}{l}\text { Improved } \\
\text { age-induced } \\
\text { deficits in } \\
\text { memory and } \\
\text { learning }\end{array}$ & n.a. & n.a. & $\begin{array}{l}\text { (E1 Idrissi, } \\
\text { Shen et al. } \\
\text { 2013) }\end{array}$ \\
\hline \multirow[t]{2}{*}{ Mice } & $43 \mathrm{mg} / \mathrm{kg}$, s.c. & Acute & $\begin{array}{l}\text { Decreased } \\
\text { anxiety }\end{array}$ & \multirow[t]{2}{*}{ n.a. } & \multirow[t]{2}{*}{ n.a. } & \multirow{2}{*}{$\begin{array}{l}\text { (Idrissi, } \\
\text { Boukarrou et } \\
\text { al. 2009) }\end{array}$} \\
\hline & $\begin{array}{l}0.05 \% \text {, oral } \\
\text { (drinking } \\
\text { water) }\end{array}$ & $\begin{array}{l}\text { Daily } \\
\text { For } 4 \text { weeks }\end{array}$ & $\begin{array}{l}\text { Increased } \\
\text { anxiety }\end{array}$ & & & \\
\hline Zebrafish & $\begin{array}{l}42-400 \mathrm{mg} / \mathrm{L}, \\
\text { in a water } \\
\text { beaker }\end{array}$ & $\begin{array}{l}\text { Acute } \\
\text { For } 1 \mathrm{~h}, \\
\text { before } \\
\text { behavioral } \\
\text { test }\end{array}$ & $\begin{array}{l}\text { Decreased } \\
\text { anxiety }\end{array}$ & n.a. & n.a. & $\begin{array}{l}\text { (Mezzomo, } \\
\text { Silveira et al. } \\
2016)\end{array}$ \\
\hline $\begin{array}{l}\text { Zebrafish } \\
\text { Exposed to } \\
\text { acute stress }\end{array}$ & $\begin{array}{l}42-400 \mathrm{mg} / \mathrm{L} \text {, } \\
\text { in a water } \\
\text { beaker }\end{array}$ & $\begin{array}{l}\text { Acute } \\
\text { For } 1 \mathrm{~h}, \\
\text { before } \\
\text { behavioral } \\
\text { tests }\end{array}$ & $\begin{array}{l}\text { Decreased } \\
\text { anxiety/fear- } \\
\text { like behavior } \\
\text { induced by } \\
\text { acute-stress }\end{array}$ & n.a. & $\begin{array}{l}\text { Prevented } \\
\text { stress- } \\
\text { induced } \\
\text { protein } \\
\text { oxidation } \\
\text { (brain) }\end{array}$ & $\begin{array}{l}\text { (Mezzomo, } \\
\text { Fontana et al. } \\
2019)\end{array}$ \\
\hline $\begin{array}{l}\text { Rats } \\
\text { Exposed to } \\
\text { chronic } \\
\text { unpredictable } \\
\text { mild stress }\end{array}$ & $\begin{array}{l}200-500 \\
\mathrm{mg} / \mathrm{kg}, \text { i.p. }\end{array}$ & $\begin{array}{l}\text { Daily } \\
\text { For } 7 \text { days } \\
\text { before }+28 \\
\text { days during } \\
\text { the stress } \\
\text { period }\end{array}$ & $\begin{array}{l}\text { Prevented } \\
\text { anxiety, } \\
\text { depression- } \\
\text { like behavior } \\
\text { and cognitive } \\
\text { impairments } \\
\text { induced by } \\
\text { stress }\end{array}$ & n.a. & n.a. & $\begin{array}{l}\text { (Wu, Ren et } \\
\text { al. 2017) }\end{array}$ \\
\hline $\begin{array}{l}\text { Rats } \\
\text { D-galactose } \\
\text { aging model }\end{array}$ & $\begin{array}{l}2.5 \% \mathrm{w} / \mathrm{w}, \\
\text { oral (chow) }\end{array}$ & $\begin{array}{l}\text { Daily } \\
\text { For } 2 \text { months }\end{array}$ & n.a. & $\begin{array}{l}\text { Restored } \\
\text { galactose- } \\
\text { induced }\end{array}$ & $\begin{array}{l}\text { Prevented } \\
\text { galactose- } \\
\text { induced }\end{array}$ & $\begin{array}{l}\text { (Aydın, } \\
\text { Çoban et al. } \\
2016)\end{array}$ \\
\hline
\end{tabular}




\begin{tabular}{|c|c|c|c|c|c|c|}
\hline & & & & $\begin{array}{l}\text { decrease in } \\
\text { GSH (brain) }\end{array}$ & $\begin{array}{l}\text { peroxidation } \\
\text { (MDA) and } \\
\text { protein } \\
\text { oxidation } \\
\text { (brain) }\end{array}$ & \\
\hline $\begin{array}{l}\text { Mice } \\
\text { Treated with } \\
\text { carbon } \\
\text { tetrachloride } \\
\text { (CC14) }\end{array}$ & $\begin{array}{l}10,20 \text { and } 40 \\
\mathrm{mg} / \mathrm{Kg} \text {, oral } \\
\text { (i.g.) }\end{array}$ & $\begin{array}{l}\text { Daily } \\
\text { For } 45 \text { days }\end{array}$ & n.a. & n.a. & $\begin{array}{l}\text { Increased } \\
\text { SOD activity } \\
\text { in medulla, } \\
\text { induces GPx } \\
\text { activity in } \\
\text { cerebrum, } \\
\text { cerebellum } \\
\text { and medulla } \\
\end{array}$ & $\begin{array}{l}\text { (Vohra and } \\
\text { Hui 2001) }\end{array}$ \\
\hline $\begin{array}{l}\text { Mice } \\
\text { D-galactose } \\
\text { aging model }\end{array}$ & $\begin{array}{l}100-400 \\
\mathrm{mg} / \mathrm{kg} \text {, oral } \\
\text { (i.g.) }\end{array}$ & $\begin{array}{l}\text { Daily } \\
\text { For } 9 \text { weeks }\end{array}$ & $\begin{array}{l}\text { Prevented } \\
\text { galactose- } \\
\text { induced } \\
\text { memory } \\
\text { decline }\end{array}$ & $\begin{array}{l}\text { Restored } \\
\text { galactose- } \\
\text { induced } \\
\text { decrease in } \\
\text { GSH (brain) }\end{array}$ & $\begin{array}{l}\text { Prevented } \\
\text { galactose- } \\
\text { induced } \\
\text { increase in } \\
\text { lipid } \\
\text { peroxidation } \\
\text { (TBARS) and } \\
\text { decrease in } \\
\text { SOD, } \\
\text { catalase and } \\
\text { GPx activity } \\
\text { (brain) }\end{array}$ & $\begin{array}{l}\text { (Tu, Chang et } \\
\text { al. 2018) }\end{array}$ \\
\hline Rats & $\begin{array}{l}\text { WP } \\
\text { concentrate } \\
0.3 \\
\mathrm{mg} / \mathrm{kg} / \mathrm{day}, \\
\text { oral (chow) } \\
\end{array}$ & $\begin{array}{l}\text { Daily } \\
\text { For } 14 \text { days }\end{array}$ & n.a. & $\begin{array}{l}\text { Increased } \\
\text { GSH in } \\
\text { salivary } \\
\text { glands }\end{array}$ & $\begin{array}{l}\text { Increased } \\
\text { SOD and } \\
\text { GPx activity } \\
\text { in salivary } \\
\text { glands }\end{array}$ & $\begin{array}{l}\text { (Falkowski, } \\
\text { Maciejczyk et } \\
\text { al. 2018) }\end{array}$ \\
\hline Rats & $\begin{array}{l}\text { WP } \\
\text { concentrate } \\
1 \mathrm{~g} / \mathrm{kg} / \text { day, } \\
\text { oral (chow) }\end{array}$ & $\begin{array}{l}\text { Daily } \\
\text { For } 28 \text { days }\end{array}$ & n.a. & $\begin{array}{l}\text { Increased } \\
\text { GSH in } \\
\text { peripheral } \\
\text { tissues; } \\
\text { unchanged in } \\
\text { the brain }\end{array}$ & $\begin{array}{l}\text { Decreased } \\
\text { lipid } \\
\text { peroxidation } \\
\text { (TBARS) and } \\
\text { protein } \\
\text { oxidation in } \\
\text { brain and } \\
\text { peripheral } \\
\text { tissues }\end{array}$ & $\begin{array}{l}\text { (Kerasioti, } \\
\text { Stagos et al. } \\
2018 \text { ) }\end{array}$ \\
\hline $\begin{array}{l}\text { Rat cerebellar } \\
\text { granule } \\
\text { neurons }\end{array}$ & $\begin{array}{l}3 \% \mathrm{WP} \\
\text { concentrate } \\
\text { (Immunocal }^{\circledR} \\
\text { ) in culture } \\
\text { medium }\end{array}$ & $\begin{array}{l}\text { Pre-treatment } \\
\text { of } 24 \mathrm{~h}+ \\
\text { treatment of } \\
24 \mathrm{~h}\end{array}$ & - & $\begin{array}{l}\text { Increased } \\
\text { GSH in } \\
\text { neurons } \\
\text { treated with } \\
\text { HA14-1 (pro- } \\
\text { apoptotic } \\
\text { drug) }\end{array}$ & n.a. & $\begin{array}{l}\text { (Winter, Ross } \\
\text { et al. 2017) }\end{array}$ \\
\hline $\begin{array}{l}\text { Motor } \\
\text { neuron-like } \\
\text { NSC-34 cell } \\
\text { line }\end{array}$ & $\begin{array}{l}3 \% \text { WP } \\
\text { concentrate } \\
\text { (Immunocal }^{\circledR} \\
\text { ) in culture } \\
\text { medium }\end{array}$ & $\begin{array}{l}\text { Pre-treatment } \\
\text { of } 24 \mathrm{~h}+ \\
\text { treatment of } \\
24 \mathrm{~h}\end{array}$ & - & n.a. & $\begin{array}{l}\text { Increases cell } \\
\text { viability in } \\
\text { cells treated } \\
\text { with } \mathrm{H}_{2} \mathrm{O}_{2}\end{array}$ & $\begin{array}{l}\text { (Winter, Ross } \\
\text { et al. 2017) }\end{array}$ \\
\hline
\end{tabular}




\begin{tabular}{|c|c|c|c|c|c|c|}
\hline Mice & $\begin{array}{l}33 \mathrm{mg} \text { WP } \\
\text { concentrate } \\
\text { (Immunocal }^{\circledR} \\
\text { )/mL, oral } \\
\text { (drinking } \\
\text { water) }\end{array}$ & $\begin{array}{l}\text { Daily } \\
\text { For } 6 \text { weeks }\end{array}$ & n.a. & $\begin{array}{l}\text { Increased } \\
\text { GSH (brain) }\end{array}$ & n.a. & $\begin{array}{l}\text { (Song, } \\
\text { Tavitian et al. } \\
2017 \text { ) }\end{array}$ \\
\hline $\begin{array}{l}\text { Human } \\
\text { Patients with } \\
\text { Parkinson`s } \\
\text { disease }\end{array}$ & $\begin{array}{l}20 \mathrm{~g} \mathrm{WP} \\
\text { concentrate } \\
\text { (Immunocal }^{\circledR} \\
\text { )/day, oral } \\
\text { (drinking } \\
\text { water) }\end{array}$ & $\begin{array}{l}\text { Twice daily } \\
\text { (10 g) } \\
\text { For } 6 \text { months }\end{array}$ & $\begin{array}{l}\text { No } \\
\text { significant } \\
\text { changes in } \\
\text { clinical } \\
\text { outcomes }\end{array}$ & $\begin{array}{l}\text { Increased } \\
\text { GSH } \\
\text { (plasma) }\end{array}$ & n.a. & $\begin{array}{l}\text { (Tosukhowon } \\
\text { g, Boonla et } \\
\text { al. 2016) }\end{array}$ \\
\hline Mice & $\begin{array}{l}\text { Oral (chow } \\
\text { containing } \\
170 \mathrm{~g} \text { of } \alpha- \\
\text { lactalbumin } / \mathrm{k} \\
\mathrm{g} \text { ) }\end{array}$ & $\begin{array}{l}\text { Daily } \\
\text { For } 3 \text { weeks }\end{array}$ & $\begin{array}{l}\text { Reduced the } \\
\text { short } \\
\text { photoperiod- } \\
\text { induced } \\
\text { anxiety-like } \\
\text { behavior }\end{array}$ & n.a. & n.a. & $\begin{array}{l}\text { (Otsuka, } \\
\text { Goda et al. } \\
2015)\end{array}$ \\
\hline Mice & $\begin{array}{l}\text { Peptide } \\
\text { wheylin-1: } \\
1 \mathrm{mg} / \mathrm{kg} \text {, oral } \\
\text { (i.g) or, } \\
0.3-1 \mathrm{mg} / \mathrm{kg} \text {, } \\
\text { i.p. or } \\
4 \mu \mathrm{l} \text { i.c.v. }\end{array}$ & $\begin{array}{l}\text { Acute } \\
30 \text { min before } \\
\text { behavioral } \\
\text { test }\end{array}$ & $\begin{array}{l}\text { Decreased } \\
\text { anxiety-like } \\
\text { behavior }\end{array}$ & n.a. & n.a. & $\begin{array}{l}\text { (Yamada, } \\
\text { Mizushige et } \\
\text { al. 2014) }\end{array}$ \\
\hline Mice & $\begin{array}{l}\text { Peptide } \\
\text { wheylin-2: } \\
1-3 \mathrm{mg} / \mathrm{kg} \text {, } \\
\text { i.p. }\end{array}$ & $\begin{array}{l}\text { Acute } \\
30 \text { min before } \\
\text { behavioral } \\
\text { test }\end{array}$ & $\begin{array}{l}\text { Decreased } \\
\text { anxiety-like } \\
\text { behavior }\end{array}$ & n.a. & n.a. & $\begin{array}{l}\text { (Yamada, } \\
\text { Mizushige et } \\
\text { al. 2014) }\end{array}$ \\
\hline Mice & $\begin{array}{l}\text { Peptide } \beta \text { - } \\
\text { lactotensin: } \\
1-10 \mathrm{mg} / \mathrm{kg} \text {, } \\
\text { i.p. or } \\
\text { 3-10 } \mathrm{mg} / \mathrm{kg} \text {, } \\
\text { oral }\end{array}$ & $\begin{array}{l}\text { Acute } \\
30 \text { min before } \\
\text { behavioral } \\
\text { test }\end{array}$ & $\begin{array}{l}\text { Decreased } \\
\text { anxiety-like } \\
\text { behavior }\end{array}$ & n.a. & n.a. & $\begin{array}{l}\text { (Hou, Suzuki } \\
\text { et al. 2011) }\end{array}$ \\
\hline $\begin{array}{l}\text { Human } \\
\text { High-anxiety } \\
\text { trait }\end{array}$ & $\begin{array}{l}\text { Daily intake } \\
\text { of } 125 \mathrm{~g} \text { of } \\
\text { yogurt } \\
\text { (normal or } \\
\text { enriched with } \\
\alpha- \\
\text { lactalbumin }+ \\
\text { other peptides } \\
\text { and vitamins) }\end{array}$ & $\begin{array}{l}\text { Daily } \\
\text { For } 4 \text { weeks }\end{array}$ & $\begin{array}{l}\text { Increased } \\
\text { ratings of } \\
\text { vigor, heart } \\
\text { rate } \\
\text { variability } \\
\text { and recovery } \\
\text { index. } \\
\text { Decreased } \\
\text { feeling of } \\
\text { inefficiency. }\end{array}$ & n.a. & n.a. & $\begin{array}{l}\text { (Jaatinen, } \\
\text { Korpela et al. } \\
2014 \text { ) }\end{array}$ \\
\hline
\end{tabular}

Notes. dROMS: diacron reactive oxygen metabolites; GPx: glutathione peroxidase; GSH: reduced glutathione; GSSG: oxidized glutathione; intra-PAG: intra-periaqueductal grey; i.p.: intraperitoneal; i.g.: intragastric, gavage; i.c.v.: intracerebroventricular; MDA: malondialdehyde; n.a.: not assessed; s.c.: subcutaneous; SOD: superoxide dismutase; TBARS: Thiobarbituric acid reactive substances.

Table 2. List of NRF2 activators and their impact on behavior, GSH levels and oxidative damage. 


\begin{tabular}{|c|c|c|c|c|c|c|}
\hline Model & $\begin{array}{l}\text { Dose and } \\
\text { route of } \\
\text { administratio } \\
n\end{array}$ & $\begin{array}{l}\text { Duration } \\
\text { treatment }\end{array}$ & $\begin{array}{l}\text { Impact on } \\
\text { behavior }\end{array}$ & $\begin{array}{l}\text { Modification } \\
\text { in GSH } \\
\text { levels }\end{array}$ & $\begin{array}{l}\text { Oxidative } \\
\text { damage }\end{array}$ & Reference \\
\hline $\begin{array}{l}\text { Human U373 } \\
\text { astroglial } \\
\text { cells }\end{array}$ & $\begin{array}{l}5-10 \mu \mathrm{M} \text { in } \\
\text { culture } \\
\text { medium }\end{array}$ & $48 \mathrm{~h}$ & - & $\begin{array}{l}\text { Increased } \\
\text { extracellular } \\
\text { GSH }\end{array}$ & n.a. & $\begin{array}{l}\text { (Steele, Fuller } \\
\text { et al. 2013) }\end{array}$ \\
\hline $\begin{array}{l}\text { Human } \\
\text { Healthy adult } \\
\text { subjects }\end{array}$ & $\begin{array}{l}100 \mu \mathrm{mol}, \\
\text { oral }\end{array}$ & $\begin{array}{l}\text { Daily } \\
\text { For } 1 \text { week }\end{array}$ & n.a. & $\begin{array}{l}\text { Increased } \\
\text { total GSH } \\
\text { levels (blood } \\
\text { and brain: } \\
\text { hippocampus } \\
\text { and thalamus) }\end{array}$ & n.a. & $\begin{array}{l}\text { (Sedlak, } \\
\text { Nucifora et al. } \\
2017)\end{array}$ \\
\hline Mice & $\begin{array}{l}\text { 3-10 mg/kg, } \\
\text { i.p. }\end{array}$ & $\begin{array}{l}\text { Daily } \\
\text { For } 14 \text { days }\end{array}$ & $\begin{array}{l}\text { Reduced } \\
\text { depression- } \\
\text { like and } \\
\text { anxiety-like } \\
\text { behavior }\end{array}$ & n.a. & n.a. & $\begin{array}{l}\text { (Wu, Gao et } \\
\text { al. 2016) }\end{array}$ \\
\hline $\begin{array}{l}\text { Mice } \\
\text { Exposed to } \\
\text { chronic } \\
\text { unpredictable } \\
\text { mild stress }\end{array}$ & $10 \mathrm{mg} / \mathrm{kg}$, i.p. & $\begin{array}{l}\text { Daily } \\
\text { For } 14 \text { days, } \\
\text { from day } 14^{\text {th }} \\
\text { until the last } \\
\text { day of the } \\
\text { stress period }\end{array}$ & $\begin{array}{l}\text { Prevented } \\
\text { stress- } \\
\text { induced } \\
\text { anxiety- and } \\
\text { depressive- } \\
\text { like behaviors }\end{array}$ & n.a. & n.a. & $\begin{array}{l}\text { (Wu, Gao et } \\
\text { al. 2016) }\end{array}$ \\
\hline $\begin{array}{l}\text { Mice } \\
\text { Model of } \\
\text { neuropathic } \\
\text { pain induced } \\
\text { by chronic } \\
\text { constriction } \\
\text { of the sciatic } \\
\text { nerve (CCI) }\end{array}$ & $10 \mathrm{mg} / \mathrm{kg}$, i.p. & $\begin{array}{l}\text { Daily } \\
\text { For } 15 \text { days, } \\
\text { starting } 14 \\
\text { days after the } \\
\text { CCI }\end{array}$ & $\begin{array}{l}\text { Ameliorated } \\
\text { anxiety- and } \\
\text { depression- } \\
\text { like behavior } \\
\text { induced by } \\
\text { CCI }\end{array}$ & n.a. & $\begin{array}{l}\text { Reversed } \\
\text { CCI-induced } \\
\text { decrease in } \\
\text { Nrf2 protein } \\
\text { levels (spinal } \\
\text { cord and } \\
\text { brain: } \\
\text { hippocampus } \\
\text { and prefrontal } \\
\text { cortex) }\end{array}$ & $\begin{array}{l}\text { (Ferreira- } \\
\text { Chamorro, } \\
\text { Redondo et al. } \\
2018 \text { ) }\end{array}$ \\
\hline $\begin{array}{l}\text { Mice } \\
\text { Exposed to } \\
\text { chronic } \\
\text { unpredictable } \\
\text { mild stress }\end{array}$ & $\begin{array}{l}25 \mathrm{mg} / \mathrm{kg} \text {, } \\
\text { oral (i.g.) }\end{array}$ & $\begin{array}{l}\text { Daily, 1h } \\
\text { before each } \\
\text { stress session } \\
\text { For } 8 \text { weeks, } \\
\text { during the } \\
\text { stress period }\end{array}$ & $\begin{array}{l}\text { Prevented } \\
\text { anxiety- and } \\
\text { depression- } \\
\text { like behaviors } \\
\text { induced by } \\
\text { stress }\end{array}$ & $\begin{array}{l}\text { Prevented } \\
\text { stress- } \\
\text { induced } \\
\text { decrease in } \\
\text { GSH (brain: } \\
\text { hippocampus } \\
\text { ) }\end{array}$ & $\begin{array}{l}\text { Prevented } \\
\text { stress- } \\
\text { induced } \\
\text { increase in } \\
\text { lipid } \\
\text { peroxidation } \\
\text { (MDA) } \\
\text { (brain: } \\
\text { hippocampus } \\
\text { ) }\end{array}$ & $\begin{array}{l}\text { (Abd El- } \\
\text { Fattah, Fahim } \\
\text { et al. 2018) }\end{array}$ \\
\hline $\begin{array}{l}\text { Cortical } \\
\text { primary } \\
\text { neurons and } \\
\text { hippocampal } \\
\text { neurons }\end{array}$ & $\begin{array}{l}10 \mu \mathrm{M} \text { in } \\
\text { culture } \\
\text { medium }\end{array}$ & $\begin{array}{l}\text { Pre-treatment } \\
\text { for } 24 \mathrm{~h} \\
\text { before adding } \\
\text { glutamate in } \\
\text { the medium }\end{array}$ & - & $\begin{array}{l}\text { Prevented } \\
\text { glutamate- } \\
\text { induced } \\
\text { neurotoxicity } \\
\text { and decrease } \\
\text { in } \\
\text { intracellular } \\
\text { GSH }\end{array}$ & $\begin{array}{l}\text { Increased } \\
\text { Nrf2 nuclear } \\
\text { protein levels } \\
\text { and gene } \\
\text { expression of } \\
\text { GCL and } \\
\text { SLC7A11 }\end{array}$ & $\begin{array}{l}\text { (Albrecht, } \\
\text { Bouchachia et } \\
\text { al. 2012) }\end{array}$ \\
\hline
\end{tabular}




\begin{tabular}{|c|c|c|c|c|c|c|}
\hline $\begin{array}{l}\text { Mice } \\
\text { Exposed to } \\
\text { traumatic } \\
\text { brain injury } \\
\text { (TBI) }\end{array}$ & $\begin{array}{l}80 \mathrm{mg} / \mathrm{kg}, \\
\text { oral (i.g.) }\end{array}$ & $\begin{array}{l}\text { Acute } \\
\text { delivery at } 3 \\
\mathrm{~h}, 24 \mathrm{~h}, 48 \mathrm{~h} \text {, } \\
\text { and } 72 \mathrm{~h} \\
\text { post-TBI }\end{array}$ & $\begin{array}{l}\text { Attenuated } \\
\text { neurological } \\
\text { deficits and } \\
\text { reduced } \\
\text { secondary } \\
\text { brain damage } \\
\text { after TBI }\end{array}$ & $\begin{array}{l}\text { Restored } \\
\text { TBI-induced } \\
\text { decrease in } \\
\text { GSH (brain) }\end{array}$ & n.a. & $\begin{array}{l}\text { (Krämer, } \\
\text { Grob et al. } \\
2017 \text { ) }\end{array}$ \\
\hline $\begin{array}{l}\text { Cultivated } \\
\text { mouse } \\
\text { neurons and } \\
\text { astrocytes }\end{array}$ & $\begin{array}{l}10 \mu \mathrm{M} \text { in } \\
\text { culture } \\
\text { medium }\end{array}$ & $18 \mathrm{~h}$ & - & $\begin{array}{l}\text { Increased } \\
\text { GSH }\end{array}$ & $\begin{array}{l}\text { Increased } \\
\text { GCL activity }\end{array}$ & $\begin{array}{l}\text { (Lavoie, Chen } \\
\text { et al. 2009) }\end{array}$ \\
\hline $\begin{array}{l}\text { Rats } \\
\text { Rotenone- } \\
\text { induced } \\
\text { model of } \\
\text { Parkinson's } \\
\text { disease }\end{array}$ & $\begin{array}{l}100 \mathrm{mg} / \mathrm{kg} \text {, } \\
\text { oral (i.g.) }\end{array}$ & $\begin{array}{l}\text { Twice daily } \\
\text { For } 50 \text { days }\end{array}$ & $\begin{array}{l}\text { Improved } \\
\text { Parkinson's- } \\
\text { like motor } \\
\text { deficits }\end{array}$ & $\begin{array}{l}\text { Prevented } \\
\text { rotenone- } \\
\text { induced } \\
\text { decrease in } \\
\text { GSH (brain: } \\
\text { substantia } \\
\text { nigra) }\end{array}$ & $\begin{array}{l}\text { Prevented } \\
\text { rotenone- } \\
\text { induced } \\
\text { increase in } \\
\text { lipid } \\
\text { peroxidation } \\
\text { (MDA). } \\
\text { Prevented } \\
\text { rotenone- } \\
\text { induced } \\
\text { decrease in } \\
\text { Nrf2 protein } \\
\text { levels }\end{array}$ & $\begin{array}{l}\text { (Cui, Xin et } \\
\text { al. 2015) }\end{array}$ \\
\hline $\begin{array}{l}\text { Mice } \\
\text { Rotenone- } \\
\text { induced } \\
\text { model of } \\
\text { Parkinson's } \\
\text { disease }\end{array}$ & $\begin{array}{l}50-200 \\
\mathrm{mg} / \mathrm{kg} \text {, oral } \\
\text { (i.g.) }\end{array}$ & $\begin{array}{l}\text { Daily, } 1 \mathrm{~h} \\
\text { before } \\
\text { rotenone } \\
\text { For } 21 \text { days }\end{array}$ & $\begin{array}{l}\text { Improved } \\
\text { Parkinson's- } \\
\text { like motor } \\
\text { deficits }\end{array}$ & $\begin{array}{l}\text { Prevented } \\
\text { rotenone- } \\
\text { induced } \\
\text { decrease in } \\
\text { GSH (brain) }\end{array}$ & $\begin{array}{l}\text { Prevented } \\
\text { rotenone- } \\
\text { induced } \\
\text { increase in } \\
\text { lipid } \\
\text { peroxidation } \\
\text { (MDA). } \\
\text { Prevented } \\
\text { rotenone- } \\
\text { induced } \\
\text { decrease in } \\
\text { GPx activity }\end{array}$ & $\begin{array}{l}\text { (Khatri and } \\
\text { Juvekar 2016) }\end{array}$ \\
\hline $\begin{array}{l}\text { Mice } \\
\text { BSO-induced } \\
\text { model of } \\
\text { Parkinson's } \\
\text { disease }\end{array}$ & $50 \mathrm{mg} / \mathrm{kg}$, i.p. & $\begin{array}{l}\text { Daily } \\
\text { For 1-3 days }\end{array}$ & n.a. & $\begin{array}{l}\text { Prevented } \\
\text { BSO-induced } \\
\text { decrease in } \\
\text { GSH (brain) }\end{array}$ & n.a. & $\begin{array}{l}\text { (Jagatha, } \\
\text { Mythri et al. } \\
\text { 2008) }\end{array}$ \\
\hline $\begin{array}{l}\text { Mice } \\
\text { MPTP- } \\
\text { induced } \\
\text { model of } \\
\text { Parkinson's } \\
\text { disease }\end{array}$ & $24 \mathrm{mg} / \mathrm{kg}$, i.p. & $\begin{array}{l}\text { Daily, } 1 \mathrm{~h} \\
\text { prior MPTP } \\
\text { injection } \\
\text { For } 7 \text { days }\end{array}$ & $\begin{array}{l}\text { Improved } \\
\text { Parkinson's } \\
\text { like motor } \\
\text { deficits }\end{array}$ & $\begin{array}{l}\text { Prevented } \\
\text { MPTP- } \\
\text { induced } \\
\text { decrease in } \\
\text { GSH (brain: } \\
\text { substantia } \\
\text { nigra) }\end{array}$ & $\begin{array}{l}\text { Prevented } \\
\text { MPTP- } \\
\text { induced } \\
\text { increase in } \\
\text { lipid } \\
\text { peroxidation } \\
\text { (TBARS), } \\
\text { SOD and } \\
\text { catalase } \\
\text { activity. } \\
\text { Prevented } \\
\text { MPTP- }\end{array}$ & $\begin{array}{l}\text { (Jayaraj, } \\
\text { Elangovan et } \\
\text { al. 2014) }\end{array}$ \\
\hline
\end{tabular}




\begin{tabular}{|c|c|c|c|c|c|c|}
\hline & & & & & $\begin{array}{l}\text { induced } \\
\text { decrease in } \\
\text { GPx activity }\end{array}$ & \\
\hline $\begin{array}{l}\text { Rats } \\
\text { 3-NP-induced } \\
\text { model of } \\
\text { Huntingon's } \\
\text { disease }\end{array}$ & $\begin{array}{l}40 \mathrm{mg} / \mathrm{kg} \text {, } \\
\text { i.g. curcumin } \\
\text { encapsulated } \\
\text { solid lipid } \\
\text { nanoparticles }\end{array}$ & $\begin{array}{l}\text { Daily, } 1 \mathrm{~h} \\
\text { prior 3-NP } \\
\text { injection } \\
\text { For } 7 \text { days }\end{array}$ & $\begin{array}{l}\text { Improved } \\
\text { Huntington's- } \\
\text { like motor } \\
\text { deficits }\end{array}$ & $\begin{array}{l}\text { Prevented the } \\
\text { 3-NP-induced } \\
\text { decreased in } \\
\text { GSH levels } \\
\text { (brain: } \\
\text { striatum) }\end{array}$ & $\begin{array}{l}\text { Prevented 3- } \\
\text { NP-induced } \\
\text { increase in } \\
\text { lipid } \\
\text { peroxidation } \\
\text { (MDA) and } \\
\text { protein } \\
\text { oxidation. } \\
\text { Prevented 3- } \\
\text { NP-induced } \\
\text { decrease in } \\
\text { SOD activity } \\
\text { (brain: } \\
\text { striatum) }\end{array}$ & $\begin{array}{l}\text { (Sandhir, } \\
\text { Yadav et al. } \\
2014 \text { ) }\end{array}$ \\
\hline $\begin{array}{l}\text { Rats } \\
\text { Exposed to } \\
\text { chronic } \\
\text { unpredictable } \\
\text { mild stress }\end{array}$ & $40 \mathrm{mg} / \mathrm{kg}$, i.p. & $\begin{array}{l}\text { Daily, } 1 \mathrm{~h} \\
\text { prior the } \\
\text { stress session } \\
\text { For the } \\
5 \text { weeks of } \\
\text { the stress } \\
\text { period }\end{array}$ & $\begin{array}{l}\text { Reversed } \\
\text { depression- } \\
\text { like behaviors } \\
\text { induced by } \\
\text { stress }\end{array}$ & n.a. & n.a. & $\begin{array}{l}\text { (Fan, Song et } \\
\text { al. 2018) }\end{array}$ \\
\hline $\begin{array}{l}\text { Mice } \\
\text { Exposed to } \\
10 \text { days of } \\
\text { social defeat } \\
\text { stress }\end{array}$ & $\begin{array}{l}1.5 \% \text {, oral } \\
\text { (chow) }\end{array}$ & $\begin{array}{l}\text { Daily } \\
\text { For } 26 \text { days, } \\
\text { starting } 5 \\
\text { days before } \\
\text { the stress } \\
\text { period }\end{array}$ & $\begin{array}{l}\text { Increased } \\
\text { resilince to } \\
\text { social defeat. } \\
\text { Decreased } \\
\text { anxiety } \\
\text { induced by } \\
\text { stress in } \\
\text { defeated mice }\end{array}$ & n.a. & n.a. & $\begin{array}{l}\text { (Aubry, } \\
\text { Khandaker et } \\
\text { al. 2019) }\end{array}$ \\
\hline $\begin{array}{l}\text { Rats } \\
\text { Exposed to } \\
\text { chronic } \\
\text { restraint } \\
\text { stress }\end{array}$ & $\begin{array}{l}10-20 \mathrm{mg} / \mathrm{kg} \text {, } \\
\text { oral (i.g.) }\end{array}$ & $\begin{array}{l}\text { Daily } \\
\text { For } 21 \text { days, } \\
\text { during the } \\
\text { stress period }\end{array}$ & $\begin{array}{l}\text { Reversed } \\
\text { stress- } \\
\text { induced } \\
\text { impaired } \\
\text { spatial } \\
\text { memory }\end{array}$ & n.a. & n.a. & $\begin{array}{l}\text { (Xu, Lin et al. } \\
2009 \text { ) }\end{array}$ \\
\hline $\begin{array}{l}\text { Mice } \\
\text { Triple } \\
\text { transgenic } \\
\text { mice model } \\
\text { of } \\
\text { Alzheimer's } \\
\text { disease } \\
\text { (3xTg-AD) }\end{array}$ & $\begin{array}{l}10 \mathrm{mg} / \mathrm{kg} \text {, } \\
\text { oral (drinking } \\
\text { water) }\end{array}$ & $\begin{array}{l}\text { Daily } \\
\text { For } 1 \text { month }\end{array}$ & $\begin{array}{l}\text { Ameliorated } \\
\text { anxiety- and } \\
\text { depression- } \\
\text { like behavior } \\
\text { in } 3 x T g-A D \\
\text { mice }\end{array}$ & n.a. & n.a. & $\begin{array}{l}\text { (Nie, Wei et } \\
\text { al. 2017) }\end{array}$ \\
\hline $\begin{array}{l}\text { Mice } \\
\text { LPS-treated }\end{array}$ & $10 \mathrm{mg} / \mathrm{kg}$, i.p. & $\begin{array}{l}\text { Acute } \\
\text { treatment } 30 \\
\text { min before } \\
\text { LPS-injection } \\
24 \text { h before } \\
\text { behavioral } \\
\text { testing }\end{array}$ & $\begin{array}{l}\text { Prevented the } \\
\text { LPS-induced } \\
\text { increases in } \\
\text { depression- } \\
\text { like behavior }\end{array}$ & $\begin{array}{l}\text { Prevented } \\
\text { LPS-induced } \\
\text { decrease in } \\
\text { GSH (brain: } \\
\text { hippocampus } \\
\text { ) }\end{array}$ & $\begin{array}{l}\text { Prevented } \\
\text { LPS-induced } \\
\text { increase in } \\
\text { lipid } \\
\text { peroxidation } \\
\text { (TBARS) }\end{array}$ & $\begin{array}{l}\text { (Taniguti, } \\
\text { Ferreira et al. } \\
\text { 2018) }\end{array}$ \\
\hline
\end{tabular}




\begin{tabular}{|c|c|c|c|c|c|c|}
\hline $\begin{array}{l}\text { Mice } \\
\text { Dexamethaso } \\
\text { ne-treated }\end{array}$ & 10 mg/kg i.p. & $\begin{array}{l}\text { For } 21 \text { days } \\
\text { before } \\
\text { dexamethaso } \\
\text { ne treatment }\end{array}$ & $\begin{array}{l}\text { Prevented the } \\
\text { dexamethaso } \\
\text { ne-induced } \\
\text { increase in } \\
\text { depression } \\
\text { like behavior }\end{array}$ & n.a. & n.a. & $\begin{array}{l}\text { (Ruksee, } \\
\text { Tongjaroenbu } \\
\text { angam et al. } \\
2014 \text { ) }\end{array}$ \\
\hline $\begin{array}{l}\text { Rats } \\
\text { Exposed to } \\
\text { chronic } \\
\text { unpredictable } \\
\text { mild stress }\end{array}$ & $10 \mathrm{mg} / \mathrm{kg}$, i.p. & $\begin{array}{l}\text { Daily, } \\
\text { following the } \\
\text { end of the } \\
\text { stress period } \\
\text { For } 2 \text { weeks }\end{array}$ & $\begin{array}{l}\text { Prevented the } \\
\text { stress- } \\
\text { induced } \\
\text { increase in } \\
\text { depression- } \\
\text { and anxiety- } \\
\text { like behavior }\end{array}$ & n.a. & n.a. & $\begin{array}{l}\text { (Sun, Wang et } \\
\text { al. 2017) }\end{array}$ \\
\hline $\begin{array}{l}\text { Rats } \\
\text { Young and } \\
\text { aged rats } \\
\text { exposed } \\
\text { chronic } \\
\text { ethanol } \\
\text { consumption }\end{array}$ & 10 mg/kg i.p. & $\begin{array}{l}\text { Daily during } \\
\text { ethanol } \\
\text { exposure } \\
\text { For } 45 \text { days }\end{array}$ & $\begin{array}{l}\text { Improved } \\
\text { ethanol- } \\
\text { induced } \\
\text { learning and } \\
\text { memory } \\
\text { deficits in } \\
\text { water maze } \\
\text { and passive } \\
\text { avoidance } \\
\text { tests }\end{array}$ & $\begin{array}{l}\text { Prevented } \\
\text { ethanol- } \\
\text { induced } \\
\text { decrease of } \\
\text { GSH (brain: } \\
\text { hippocampus } \\
\text { and cortex) }\end{array}$ & $\begin{array}{l}\text { Prevented } \\
\text { ethanol- } \\
\text { induced } \\
\text { increase in } \\
\text { lipid } \\
\text { peroxidation } \\
\text { (MDA+4- } \\
\text { HDA; brain: } \\
\text { hippocampus, } \\
\text { cortex) }\end{array}$ & $\begin{array}{l}\text { (Baydas and } \\
\text { Tuzcu 2005) }\end{array}$ \\
\hline $\begin{array}{l}\text { Mice } \\
\text { Exposed to } \\
\text { chronic } \\
\text { ethanol, } \\
\text { restraint, or } \\
\text { ethanol+restr } \\
\text { aint stress }\end{array}$ & $\begin{array}{l}20 \mathrm{mg} / \mathrm{kg} \text {, } \\
\text { oral }\end{array}$ & $\begin{array}{l}\text { Daily during } \\
\text { the last } 2 \\
\text { weeks of the } \\
\text { 4-weeks } \\
\text { stress } \\
\text { exposure }\end{array}$ & $\begin{array}{l}\text { Improved } \\
\text { ethanol- } \\
\text { and/or stress- } \\
\text { induced } \\
\text { learning and } \\
\text { memory } \\
\text { deficits in } \\
\text { water maze } \\
\text { and novel } \\
\text { object } \\
\text { recognition }\end{array}$ & $\begin{array}{l}\text { Increased } \\
\text { ethanol/stress } \\
\text {-induced } \\
\text { decrease of } \\
\text { GSH (brain: } \\
\text { hippocampus } \\
\text { ) }\end{array}$ & $\begin{array}{l}\text { Decreased } \\
\text { ethanol/stress } \\
\text {-induced } \\
\text { increase in } \\
\text { TBARS } \\
\text { (brain: } \\
\text { hippocampus } \\
\text { ) }\end{array}$ & $\begin{array}{l}\text { (Rajput, } \\
\text { Jangra et al. } \\
\text { 2017) }\end{array}$ \\
\hline Hep1-6 cells & $50 \mathrm{mM}$ & $24 \mathrm{~h}$ & - & n.a. & $\begin{array}{l}\text { Increased } \\
\text { Nrf2 nuclear } \\
\text { translocation } \\
\text { and } \\
\text { expression of } \\
\text { Ho-1 and } \\
\text { Nqo1. } \\
\text { Decreased } \\
\text { paraquat- } \\
\text { induced ROS } \\
\text { production }\end{array}$ & $\begin{array}{l}\text { (Mizunoe, } \\
\text { Kobayashi et } \\
\text { al. 2018) }\end{array}$ \\
\hline
\end{tabular}




\begin{tabular}{|c|c|c|c|c|c|c|}
\hline $\begin{array}{l}\text { Rats } \\
\text { Intoxication } \\
\text { withcadmium } \\
\text { chloride } \\
\left(\mathrm{CdCl}_{2}\right)\end{array}$ & $\begin{array}{l}2 \mathrm{~g} / \mathrm{kg} \text {, oral } \\
\text { (i.g) }\end{array}$ & $\begin{array}{l}\text { Daily } \\
\text { During the } 8 \\
\text { weeks of } \\
\text { intoxication } \\
\text { with } \mathrm{CdCl}_{2}\end{array}$ & n.a. & n.a. & $\begin{array}{l}\text { Decreased } \\
\mathrm{CdCl}_{2-} \\
\text { induced Nrf2 } \\
\text { nuclear } \\
\text { translocation } \\
\text { and lipid } \\
\text { peroxidation } \\
\text { (MDA) } \\
\text { (whole brain } \\
\text { homogenates) }\end{array}$ & $\begin{array}{l}\text { (Tang, Liu et } \\
\text { al. 2019) }\end{array}$ \\
\hline $\begin{array}{l}\text { Mice } \\
\text { Overexpressi } \\
\text { ng human } \\
\text { mutated tau } \\
\text { protein with } \\
\text { deletion of } \\
\text { parkin } \\
\left(\mathrm{PK}^{-/-} / \mathrm{Tau} \mathrm{V}^{\mathrm{L}}\right. \\
\mathrm{W}) ; \text { Model of } \\
\text { tauopathy } \\
\text { with } \\
\text { parkinsonism }\end{array}$ & $\begin{array}{l}1 \% \text {, oral } \\
\text { (drinking } \\
\text { water) }\end{array}$ & $\begin{array}{l}\text { Daily } \\
\text { For } 2.5 \text { to } 4 \\
\text { months }\end{array}$ & $\begin{array}{l}\text { Increase } \\
\text { motor activity } \\
\text { and decrease } \\
\text { anxiety }\end{array}$ & $\begin{array}{l}\text { Increase GSH } \\
\text { (brain: } \\
\text { striatum) }\end{array}$ & n.a. & $\begin{array}{l}\text { (Rodríguez- } \\
\text { Navarro, } \\
\text { Rodríguez et } \\
\text { al. 2010) }\end{array}$ \\
\hline $\begin{array}{l}\text { Mice } \\
\text { Aged mice } \\
\text { 25-months- } \\
\text { old }\end{array}$ & $\begin{array}{l}2 \% \text {, oral } \\
\text { (drinking } \\
\text { water) }\end{array}$ & $\begin{array}{l}\text { Daily, } \\
\text { For } 1 \text { month }\end{array}$ & $\begin{array}{l}\text { Improved } \\
\text { motor } \\
\text { performance } \\
\text { (in males, not } \\
\text { in females) }\end{array}$ & n.a. & $\begin{array}{l}\text { Increased } \\
\text { Nrf2 levels } \\
\text { (brain: frontal } \\
\text { cortex; in } \\
\text { males, not in } \\
\text { females) }\end{array}$ & $\begin{array}{l}\text { (Berry, } \\
\text { Marconi et al. } \\
\text { 2020) }\end{array}$ \\
\hline $\begin{array}{l}\text { Mice } \\
\text { Intoxication } \\
\text { with } \\
\text { Manganese } \\
\text { (II) chloride } \\
\left(\mathrm{MnCl}_{2}\right)\end{array}$ & $\begin{array}{l}2 \%-4 \% \text {, oral } \\
\text { (drinking } \\
\text { water) }\end{array}$ & $\begin{array}{l}\text { Daily } \\
\text { During the } 6 \\
\text { weeks of } \\
\text { intoxication } \\
\text { with } \mathrm{MnCl}_{2} \\
+/ \text { - pre- } \\
\text { treatment for } \\
1 \text { week } \\
\text { before } \\
\text { intoxication }\end{array}$ & n.a. & n.a. & $\begin{array}{l}\text { Decreased } \\
\mathrm{MnCl}_{2-} \\
\text { induced ROS } \\
\text { production } \\
\text { and lipid } \\
\text { peroxidation } \\
\text { (MDA). } \\
\text { Prevented } \\
\text { MnCl }_{2-} \\
\text { induced } \\
\text { decrease in } \\
\text { SOD2 } \\
\text { activity } \\
\text { (brain: } \\
\text { striatum) }\end{array}$ & $\begin{array}{l}\text { (Liu, Jing et } \\
\text { al. 2019) }\end{array}$ \\
\hline $\begin{array}{l}\text { Mice } \\
\text { Transgenic } \\
\text { mice model } \\
\text { of } \\
\text { Alzheimer`s } \\
\text { disease } \\
\text { (Tg2576) }\end{array}$ & $2 \%$, oral (i.g.) & $\begin{array}{l}\text { Daily } \\
\text { For } 31 \text { days }\end{array}$ & $\begin{array}{l}\text { Improves } \\
\text { cognitive } \\
\text { performance } \\
\text { of Tg } 2576 \\
\text { mice in the } \\
\text { Morris water } \\
\text { maze }\end{array}$ & n.a. & n.a. & $\begin{array}{l}\text { (Portbury, } \\
\text { Hare et al. } \\
2017 \text { ) }\end{array}$ \\
\hline
\end{tabular}

Notes. 3-NP: 3-nitropropionic acid; BSO: Buthionine sulphoximine; GCL: glutamate cysteine ligase; GPx: glutathione peroxidase; GSH: reduced glutathione; Ho-1: heme oxygenase-1; i.p.: intraperitoneal; i.g.: intragastric, gavage; LPS: lipopolysaccharide; MDA: malondialdehyde; MDA+4-HAD: malondialdehyde+4hydroxyalkenals; MPTP: 1-methyl-4-phenyl-1,2,3,6-tetrahydropyridine; n.a.: not assessed; Nqo1: NAD(P)H 
dehydrogenase, quinone 1; SLC7A11: cystine/glutamate exchanger; SOD: superoxide dismutase; TBARS: Thiobarbituric acid reactive substances. 